\title{
A AGRICULTURA E O AJUSTE DO SETOR EXTERNO: \\ BRASIL - DÉCADAS DE 1970 E 1980
}

\section{ALBERTO PFEIFER FILHO}

Engenheiro Agrônomo

Orientador: Prof. Dr. GUILHERME L. S. DIAS

Dissertação apresentada à Escola Superior de Agricultura "Luiz de Queiroz", da Universidade de São Paulo, para obtenção, do título de Mestre em Agronomia, Área de Concentração: Economia Agrária.

\author{
PIRACICABA \\ Estado de São Paulo - Brasil \\ Setembro - 1990
}


Ficha catalográfica preparada pela Seção de Livros da Divisão de Biblioteca e Documentação - PCAP/USP

Pfeifer Filho, Alberto

P525a A agricultura e o ajuste do setor externo; Brasil décadas de 1970 e 1980. Piracicaba, 1990.

$118 \mathrm{p}$.

Diss.(Mestre) - ESALQ

Bibliografia.

1. Economia agricola - Ajustamento - Brasil 2. Política econômica - Ajustamento - Brasil I. Escola Superior de Agricultura Luiz de Queiroz, Piracicaba

$\operatorname{CDD} 338.1$ 


\title{
A AGRICULTURA E O AJUSTE DO SETOR EXTERNO: BRASIL - DÉCADAS DE 1970 E 1980
}

\author{
ALBERTO PFEIFER FILHO
}

Aprovada em: 13.9.1990

Comissão julgadora:

Prof. Dr. Guilherme Leite da Sitva Dias ESALQ/USP

Prof. Dr. Geraldo de Camargo Barros ESALQ/USP

Prof. Dr. Cicely Moitinho do Amaral FEA/USP

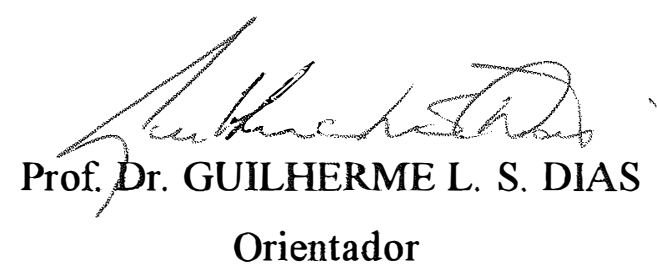


A José Pfeifer, meu avô (in memoriam) 


\section{AGRADECIMENTOS}

Ao Conselho Nacional de Desenvolvimento Científico e Tecnológico (CNPq), agradeço pelo apoio financeiro ( bolsa de estudos, de 1989 a 1990).

À Fundação Coordenação de Aperfeiçoamento de Pessoal de Nível Superior (Capes), agradeço pelo apoio financeiro (bolsa de estudos, de 1988 a 1989).

Aos professores, funcionários e colegas do Departamento de Economia e Sociologia Rural da Escola Superior de Agricultura "Luiz de Queiroz", Universidade de São Paulo, pela convivência durante as atividades do curso de Mestrado em Economia Agrária (1988 a 1990), meus profundos agradecimentos.

Aos professores, funcionários e colegas do Departamento de Economia da Faculdade de Economia e Administração, Universidade de São Paulo, pela convivência ao longo do desenvolvimento desta tese (1990), meus agradecimentos.

Ao Professor Guilherme Leite da Silva Dias, cuja orientação segura, clara e objetiva permitiu a realização desta tese e guiou os primeiros passos profissionais deste autor, meu respeito e minha gratidão.

Aos irmãos da República Covil, por todo o companheirismo, amizade e bons momentos vividos juntos.

A minha família, que forneceu a retaguarda emocional e material para esta empreitada, meu carinho e meu amor. 


\section{SUMÁRIO}

Página

LISTA DE FIGURAS............................... v

LISTA DE TABELAS................................. vi

RESUMO.................................................. vii

SUMMARY ............................................... viii

1. APRESENTAÇÃO................................... 1

2. INTRODUÇÃO............................................ 4

3. METODOLOGIA....................................... 19

3.1. Desenvolvimento da Metodologia............. 19

3.2. Base de Dados.....................................

4. RESULTADOS E DISCUSSÃO.................... 29

4.1. Das variáveis do modelo de decomposição 29

4.2. Do modelo de decomposição..................... 44

4.2.1. O subperíodo 1974-78.................. 45

4.2.2. O subperíodo 1979-83.................. 49

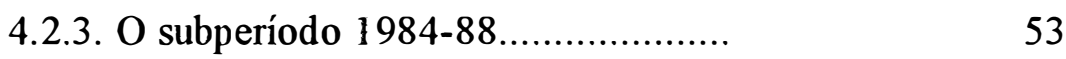

4.2.4. A contribuição do setor agrícola...... 53

5. NOTAS CONCLUSIVAS........................... 60

REFERÊNCIAS BIBLIOGRÁFICAS................. 63

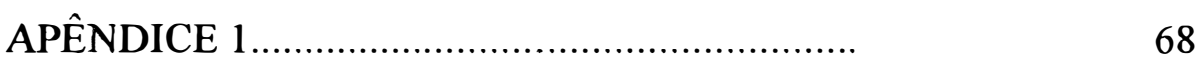

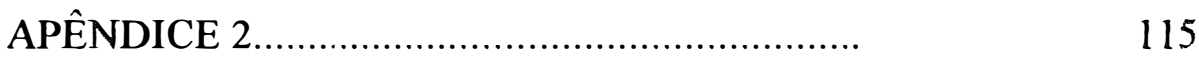




\section{LISTA DE FIGURAS}

Figura

Página

Figura 1. Saldo em transações correntes do balanço de pagamentos em 29 relação ao PNB

Figura 2. Taxas de juros (r)

Figura 3. Dívida externa em relação ao PNB (K/Y’)

Figura 4. Outras Variáveis Externas em relação ao PNB (OVE/Y')

Figura 5. Termos de troca das importações agrícolas $\left(\mathbf{P}_{\mathbf{m}}{ }^{\mathbf{a}} / \mathbf{P}_{\mathbf{y}}\right)$

Figura 6. Termos de troca das importações não-agrícolas $\left(\mathbf{P}_{\mathbf{m}}{ }^{\mathbf{n}} / \mathbf{P}_{\mathbf{y}}\right)$

Figura 7. Termos de troca das exportações agrícolas $\left(\mathbf{P}_{\mathbf{x}}{ }^{\mathbf{a}} / \mathbf{P}_{\mathbf{y}}\right)$

Figura 8. Termos de troca das exportações não-agrícolas $\left(\mathbf{P}_{\mathbf{x}}{ }^{\mathbf{n}} / \mathbf{P}_{\mathbf{y}}\right)$

Figura 9. Comércio agrícola mundial em relação ao $\mathrm{PNB}\left(\mathbf{W}_{\mathbf{a}} / \mathbf{U}^{\prime}\right)$

Figura 10. Comércio não-agrícola mundial em relação ao PNB 39 $\left(\mathbf{W}_{\mathrm{n}} / \mathbf{U}^{\prime}\right)$

Figura 11. Gasto doméstico, setor agrícola $\left(\mathbf{A}_{\mathbf{a}} / \mathbf{U}^{\prime}\right)$

Figura 12. Gasto doméstico, setor não-agrícola $\left(\mathbf{A}_{\mathbf{n}} / \mathbf{U}^{\prime}\right)$

Figura 13. Substituição de importações do setor agrícola $\left(\mathbf{J}_{\mathbf{a}} / \mathbf{A}_{\mathbf{a}}\right)$

Figura 14. Substituição de importações do setor não-agrícola $\left(\mathbf{J}_{\mathbf{n}} / \mathbf{A}_{\mathbf{a}}\right)$

Figura 15. Penetração das exportações do setor agrícola $\left(\mathbf{Z}_{\mathbf{a}} / \mathbf{W}_{\mathbf{a}}\right)$

Figura 16. Penetração das exportações do setor não-agrícola $\left(\mathbf{Z}_{\mathbf{n}} / \mathbf{W}_{\mathbf{n}}\right)$ 


\section{LISTA DE TABELAS}

Tabela

Página

Tabela 1. Brasil. Decomposição das variações dos saldos em transações 30 correntes. Preços médios do período 1971-73. PNB corrigido.

Tabela 2. Diferenças entre os valores correntes e os valores dos anos-base 30 (1971-73).

Tabela 3. Brasil. Decomposição das variações dos saldos em transações 31 correntes. Preços médios do período 1986-88. PNB corrigido

Tabela 4. Diferenças entre os valores correntes e os valores dos anos-base 31 (1986-88).

Tabela 5. Brasil. Decomposição das variações dos saldos em conta corrente, 46 entre cada ano no período 1974/78 e o ano-base de 1973 (todas as variáveis são proporções do PNB). Base de preços 1971-73.

Tabela 6. Brasil. Decomposição das variações dos saldos em conta corrente, entre cada ano no período 1979/83 e o ano-base de 1978 (todas as variáveis são proporções do PNB). Base de preços 1971-73.

Tabela 7. Brasil. Decomposição das variações dos saldos em conta corrente, entre cada ano no período 1984/88 e o ano-base de 1983 (todas as variáveis são proporções do PNB). Base de preços 1971-73.

Tabela 8. Brasil. 1974 a 1988. Contribuição do setor agrícola ao ajuste do 57 saldo em conta corrente do balanço de pagamentos, em porcentagem do PNB. Valores anuais e médias aritméticas qüinqüenais.

Tabela 9. Brasil. 1974 a 1988. Contribuição das políticas agrícolas 58 domésticas ao ajuste do saldo em conta corrente do balanço de pagamentos. Médias aritméticas qüinqüenais. 


\section{A AGRICULTURA E O AJUSTE DO SETOR EXTERNO:}

BRASIL - DÉCADAS DE 1970 E 1980

Autor: ALBERTO PFEIFER FILHO

Orientador: PROF. DR. GUILHERME LEITE DA SILVA DIAS

\section{RESUMO}

Investigou-se a contribuição do setor agrícola à economia brasileira durante o período 1973-1988, quando o país experimentou choques econômicos de origem exógena, originados na elevação dos preços do petróleo e das taxas de juros internacionais.

A literatura existente discute a participação do setor agrícola no processo de ajuste das contas nacionais: se através da garantia do abastecimento interno, ou se por meio do incremento da atividade exportadora. A hipótese deste trabalho é de que a caracterização em atender um ou outro mercado não se definiu durante o período. O setor agrícola respondeu às pressões internas de demanda, sem perder participação no mercado mundial. Tal comportamento teria ocorrido graças às transformações tecnológicas da agricultura, com a modernização da atividade produtiva e a dinamização do setor agroindustrial.

Um modelo macroeconômico foi usado para decompor o saldo em transações correntes do balanço de pagamentos, usando metodologia desenvolvida por Bela Balassa e Edmar Bacha. A presente pesquisa estende essa metodologia, subdividindo o balanço em transações correntes entre os setores agrícola e não-agrícola.

O saldo em transações correntes do balanço de pagamentos foi dividido em três grupos de fatores: (1) choques externos (subdivididos em [a] variações nos termos de troca das importações e das exportações, agrícolas e não-agrícolas; [b] taxas 
de juros e [c] variações do comércio mundial em produtos agrícolas e não-agrícolas); (2) outras variáveis externas (destacando o aumento da dívida externa); e (3) respostas de políticas domésticas ([a] variação do gasto doméstico em produtos de origem agrícola e não-agrícola; [b] substituição de importações agrícolas e não-agrícolas e [c] penetração das exportações brasileiras, agrícolas e não-agrícolas).

O período sob enfoque (1973 a 1988) foi dividido em três: 1974/78; 1979/83 e 1984/88. As variações dos fatores de decomposição são comparadas, respectivamente, aos valores dos anos-base de 1973, 1978 e 1983.

Para o subperíodo 1974/78, a variação calculada do saldo em transações correntes é deficitária. Os resultados mostram contribuição do setor agrícola ao aumento do déficit: 1,52\% (1974); 2,10\% (1975); 1,47\% (1976); 0,73\% (1977) e $2,34 \%$ (1978). Os choques externos são os principais responsáveis pelo déficit, com respostas favoráveis das políticas internas de 1975 em diante.

O grande esforço interno de ajuste ocorre no subperíodo 1979/1983. O setor agrícola se comporta assim: $0,32 \% ;-0,65 \% ;-0,72 \% ; 0,11 \%$ e $-2,13 \%$, em 1979 , 1980, 1981, 1982 e 1983, respectivamente (valores negativos indicam que a contribuição foi para a redução do déficit). A pressão pelo aumento do déficit continua a ser por meio dos choques de preços de importações, acrescidos da subida das taxas de juros. $\mathrm{O}$ ajuste advém das políticas internas implementadas, em especial quanto ao setor não-agrícola.

No último período (1984-1988), a variação do saldo em transações correntes é negativa, indicando redução do déficit. A contribuição do setor agrícola para o balanço de transações é de -0,79\% (1984), 0,25\% (1985), 2,48\% (1986), 1,88\% (1987) e $1,48 \%$ (1988). Todavia, modifica-se o padrão do ajuste. O esforço interno do período anterior é reduzido em 1984 e 1985, esgotando-se a partir de 1986. Os choques de preços das importações, favoráveis à redução do déficit, são os maiores responsáveis pelo ajuste. 


\section{THE AGRICULTURE AND THE ADJUSTMENT OF THE EXTERNAL SECTOR:}

BRAZIL, DECADES OF 1970 AND 1980

Author: ALBERTO PFEIFER FILHO

Adviser: PROF. DR. GUILHERME LEITE DA SILVA DIAS

\section{SUMMARY}

In this study the contribution of Brazil's agricultural sector to its economy during the period 1973-1988 was investigated. During this time Brazil experienced severe exogenous economic shocks caused mainly by increased oil prices and interest rates.

The recent economic literature on Brazil continues the debate on whether agriculture's contribution to its economy can be studied from an export demand or internal demand approach. The hypothesis adopted in this thesis postulates that the agricultural sector contributions can not be strictly viewed from either an export demand or internal demand framework.

During the period, 1973-1988, the value of exports as a percentage of the total GNP as well as the value of internal demand remained fairly constant. However, during the same time, the export mix and the mix of products consumed internally changed.

A macroeconomic model was used to decompose the current transactions balance of payments using methodology developed by Bela Balassa and Edmar Bacha. This research extended the methodology of Balassa and Bacha by decomposing the current transactions balance into agricultural and nonagricultural sectors. 
Three factor groups were identified: (1) external shocks (subdivided in [a] variations in terms of trade for import and export prices, agricultural and nonagricultural; $[\mathrm{b}]$ interest rates; and [c] variations in world trade in agricultural and nonagricultural products); (2) other external variables (e.g. increasing external debt); and (3) changes in internal policies ([a] domestic expenditure variations on agricultural and nonagricultural products; [b] import substitution; and [c] Brazilian export penetration). This study investigated these factors in the three subperiods; 1974/78, 1979/83 and 1984/88.

The variation of the decomposition factors for the 1974/78, 1979/83 and 1984/88 subperiods are referenced to the values from 1973, 1978 and 1983, respectively.

In the first subperiod, the calculated variation of the current transactions balance shows a deficit. The results indicate that the agricultural sector contributed to the increased deficit as a proportion of GNP. Those values were $1.52 \%$, $2.10 \%, 1.47 \%, 0.73 \%$, and $2.34 \%$ in $1974,1975,1976,1977$, and 1978 , respectively. External shocks were the most important factor explaining the increased deficit. During this subperiod, enacted domestic policies began to control the growth of the deficit.

In the secon subperiod Brazil's internal economy experienced major internal adjustments. The agricultural sector had the following behavior: $0.32 \% ;-0.65 \%$; $-0.72 \% ; 0.11 \%$; and $-2.13 \%$ in $1979,1980,1981,1982$, and 1983 , respectively (negative values indicate that the contribution was a reduction to the deficit). The internal economic responses were satisfactory, specially by the nonagricultural sector, but not enough to cover the effect of the deterioration of Brazilian import change terms, and the increasing international interest rates.

In the last subperiod (1984-1988), the variation of the transactions current balance is negative, indicating a reduction of the deficit. The contribution of the agricultural sector to the transactions balance is $-0.79 \%, 0.25 \%, 2.48 \%, 1.88 \%$, and $1.48 \%$ for $1984,1985,1986,1987$ and 1988 . Nevertheless, the internal policies changed. The internal effort is reduced in 1984 and 1985, and ends in 1986. The decreasing import prices were favorable to the reduction of the deficit. 


\section{APRESENTAÇÃo}

O comportamento da economia brasileira durante a década de 80 pode ser definido em uma palavra: crise. Alcunhados de 'década perdida', os anos 80 marcam o fim de um longo ciclo de prosperidade econômica. Esse modelo de crescimento foi caracterizado, durante os decênios de 60 e 70 , por um padrão de financiamento baseado em constantes influxos de empréstimos externos, complementares à poupança nacional. Desse modo, o volume total da poupança interna e externa possibilitou investimentos que ampliaram a capacidade produtiva do país, guindando-o à condição de economia predominantemente industrial e urbana.

Os contornos da crise tornaram-se evidentes quando ocorreu o primeiro choque de preços do petróleo (1973). O II Plano Nacional de Desenvolvimento (II PND, 1974 em diante) anteviu a possibilidade de ajustamento futuro, e criou bases industriais que permitiram a retomada do crescimento a partir de 1984. A crise concretizou-se no início da década de 80 , com a débâcle do sistema financeiro internacional e a deterioração das contas externas brasileiras. A causa primária da crise foi o estrangulamento dessas contas, devido aos crescentes déficits do balanço de serviços e da contração do nível das contas de capitais, com a redução do volume de empréstimos externos. O governo brasileiro, então, adotou uma tática de geração de divisas via saldos da balança comercial. Num primeiro momento (1981-83), instalou-se um processo recessivo. A recuperação do crescimento ocorreu em seguida (1984), graças ao dinamismo do setor exportador; a partir de 1985, também devido à forte expansão dos gastos públicos. 
A estratégia de ajuste adotada originou comportamentos diferenciados dos diversos setores econômicos. Há evidências de que o setor agrícola respondeu de modo favorável no que concerne ao abastecimento alimentar e energético interno, auxiliando na redução das importações (o que se complementou com a queda do volume de insumos agrícolas importados). As exportações agrícolas, embora tenham perdido importância relativa dentro da pauta de exportações nacionais, apontaram uma dinâmica em direção ao incremento da atividade agroindustrial. Além disso, a conjuntura mundial do comércio agrícola não permitiu uma conclusão definitiva no que diz respeito à performance desse subsetor. Cumpre lembrar que, dentro do processo de desenvolvimento econômico, o setor agrícola tende a reduzir sua participação no produto nacional e na balança comercial de um país. Fundamental é que a agricultura colabore com a manutenção e elevação dos salários reais, através do suprimento da demanda interna por bens de consumo relacionados ao setor, e com preços relativos decrescentes, $v i s$ - $a$-vis dos salários.

Considerando o processo de ajuste da economia brasileira, esta pesquisa objetiva verificar se a contribuição do setor agrícola ocorreu de modo mais intenso junto ao abastecimento interno, ou via incremento das exportações. A hipótese é de que esse direcionamento para um ou outro mercado não chega a se caracterizar, ao longo do período enfocado. Defende-se a idéia de que setor agrícola mantém sua participação relativa no mercado internacional de produtos agroindustriais e, ao mesmo tempo, pode contribuir para o decréscimo do montante de importações. A explicação para esse desempenho satisfatório residiria nos avanços tecnológicos incorporados à atividade agropecuária, que redundaram em aumento da produção via elevação da produtividade, e ao dinamismo do setor agroindustrial, conquistando mercados externos e garantindo o abastecimento interno.

O trabalho divide-se em cinco capítulos, incluindo o presente, Apresentação. O capítulo segundo, Introdução, situa a discussão recente a respeito do setor agrícola e sua inserção no processo de ajuste. Quatro seções compõe esse capítulo. 
A primeira trata de caracterizar, de modo sintético, o processo de gênese e radicação da crise. São destacados os eventos econômicos mundiais desencadeados a partir do primeiro choque do petróleo, e seus efeitos sobre a economia brasileira. É desenhado o pano de fundo para a seção seguinte, que enfoca especificamente as respostas de produção agropecuária e seu destino, se voltado para o mercado interno, se para 0 extemo, ou ainda se para ambos. A terceira seção do capítulo discute alguns ensaios concernentes aos efeitos de políticas macroeconômicas sobre o setor agrícola. Tais estudos evidenciam a discriminação que a agricultura tem sofrido, ao longo do tempo, quando são implementadas medidas de âmbito global na economia brasileira. A crise pós1973 é considerada novamente na última seção, onde são abordados alguns trabalhos acadêmicos acerca dos efeitos dos choques oriundos do exterior sobre as contas extemas do Brasil, e das respostas de políticas intermas (ambos quantificados através de um modelo similar ao que será utilizado nesta pesquisa).

O capítulo terceiro aborda a Metodologia empregada nesta pesquisa. A subseção Desenvolvimento da Metodologia descreve o modelo utilizado para se proceder à decomposição do saldo em transações correntes do balanço de pagamentos. Mostra também a divisão estabelecida para os diversos fatores de decomposição, a fim de se diferenciar o desempenho do setor agrícola do restante da economia. A segunda subseção do capítulo explicita a Base de Dados e a definição das variáveis empregadas para o cálculo dos resultados.

O capítulo quarto, Resultados e Discussão, subdivide-se em duas seções. Da primeira seção do capítulo consta a análise individualizada do comportamento de cada uma das variáveis ao longo do período enfocado, sob duas bases de ponderação (1971-73 e 1986-88). A segunda seção enuncia e discute os resultados da decomposição do saldo em transações correntes do balanço de pagamentos. O capítulo final, Conclusão, reúne algumas conclusões extraídas da discussão dos resultados. 


\section{INTRODUÇÃO}

O primeiro choque de preços internacionais do petróleo, em 1973, aconteceu quando a economia brasileira estava em um período favorável de seu processo de desenvolvimento. Era a época do chamado "milagre" brasileiro (1968-1973), na qual o conjunto dos principais indicadores econômicos apresentava excelentes performances. Durante esse período, o PIB evoluiu a taxas médias anuais de cerca de $10 \%$, com a indústria e a agricultura crescendo, respectivamente, $12,9 \%$ e $5,4 \%$ ao ano 1 .

Para o período 1974/78, o governo brasileiro buscava cumprir as metas preconizadas no II Plano Nacional de Desenvolvimento (II PND). O II PND privilegiava a implantação das indústrias de bens de capital e de produtos intermediários, substitutivos de importações. $\mathrm{O}$ objetivo final desse plano era manter o crescimento da economia próximo ao obtido durante o "milagre", de modo que o Brasil se consolidasse como uma moderna economia industrial.

Visando manter esse padrão de crescimento, as autoridades brasileiras deliberaram isolar o país da crise energética mundial, através da adoção de uma série de políticas econômicas. Uma das op̧̧ões adotadas foi a contratação de empréstimos no exterior. $O$ acesso a crédito no mercado financeiro internacional

\footnotetext{
1 Segundo CARVALHO (1989). A taxa de inflação declinou de $81 \%$ e $92 \%$ em 1963 e 1964 , respectivamente, para $15,7 \%$ em 1972 e $15,5 \%$ em 1973. Ao final de 1973 aconteceu o primeiro choque do petróleo. O preço médio (FOB) do barril passou de US\$2,54 em 1973, para US\$10,53 em 1974.
} 
encontrava-se facilitado devido à abundante oferta de eurodólares (a custos baixos), a partir de $1968^{2}$.

O endividamento externo brasileiro aumentou mais de $300 \%$ no período 1968/73, e mais de $150 \%$ no período 1974/78. Em 31/12/1979, a dívida externa líquida atingiu US\$40,22 bilhões (22,6\% do PIB). A escolha da elevação da dívida externa para alavancar o crescimento ocasionaria conseqüências financeiras e econômicas indesejáveis em breve, devido ao impacto sobre o balanço de pagamentos.

A decisão brasileira de isolar o país do choque mundial de preços de insumos energéticos ía de encontro às políticas dos países industrializados. Tais países internalizaram os novos preços do petróleo, com as conseqüentes alterações de preços relativos internos. Optaram, porém, por um ajuste não-recessivo. Foram adotadas políticas monetárias e fiscais expansionistas, o que redundou em aumento das taxas de inflação ${ }^{3}$.

Em 1979, iniciou-se o segundo choque do petróleo, cujo preço triplicou em quatro anos ${ }^{4}$. A subida das taxas de inflação dos Estados Unidos 5 levou o Federal Reserve Board (banco central norte-americano) a adotar uma política monetária restritiva que, combinada com a política fiscal expansionista adotada pelo governo Reagan ${ }^{6}$, acarretou significativo aumento das taxas de juros internacionais 7 .

2 Vide GOLDENSTEIN (1986) e FUNDAÇÃO GETÚLIO VARGAS (1981). As taxas de juros internacionais médias ficaram entre 5 e $6 \%$ no período $1971 / 72$, 9 e $10 \%$ durante $1973 / 74$ e 6 e $8 \%$ no período 1974/78 (cálculo do autor, baseado em dados do BACEN).

3 Chega-se ao fim dos anos 70 com taxas de inflação altas, taxas de juros reais negativas, políticas monetárias e fiscais expansionistas, dólar em desvalorização e déficits fiscais e comerciais dos EUA da ordem de US\$40 bilhões (MACEDO et al., 1988).

4 O preço médio do barril (FOB) vai de US\$12,23 em 1978 para US\$28,98 em 1980 e US\$34,43 em 1981 (CIEF e Petrobrás, in GALVÊAS, 1983).

5 O IPC dos Estados Unidos (variação anual): 7,1\% (1975); 6,8\% (1977); 13,3\% (1979) e 8,9\% (1981).

6 A administração Reagan implementou um programa de expansão da demanda agregada, calcado em uma política fiscal de padrão keynesiano, com redução de impostos e aumento dos gastos militares. A combinação das políticas monetária e fiscal leva ainda à valorização do dólar. São esses os principais 
O novo choque do petróleo e o aumento das taxas de juros internacionais provocaram uma forte deterioração das contas externas brasileiras. As importações de petróleo, inclusive derivados, passaram de US $\$ 4,5$ bilhões em 1978, para US\$11,3 bilhões em 1981. O custo médio anual da dívida externa brasileira passou de 7,2\% em 1978, para 17,3\% em 1982 (BACEN). A dívida cresceu, especialmente, em função da capitalização dos juros ${ }^{8}$. As despesas com juros, US $\$ 3,72$ bilhões, em média, no período 1977/79, atingiram US\$10,10 bilhões, em 1980/82.

BACHA (1984) aponta que "a dívida externa acumulou-se ao longo do período, principalmente por causa da deterioração das relações de troca, dos choques de juros e da recessão mundial" (ib., p. 613), ou seja, choques de origem externa9 9 governo brasileiro foi, sob a égide do Fundo Monetário Internacional (FMI), obrigado a corrigir os desequilíbios do balanço de pagamentos, cujo déficit alcançou US $\$ 8,83$ bilhões em 1982.

Políticas contracionistas da demanda interna foram adotadas a partir da segunda metade de 1980 até meados de 1984. Houve elevação das taxas de juros reais internas $^{10}$, corte nos gastos públicos (principalmente investimento) ${ }^{\mathbf{1 1}}$ e declínio real dos salários $^{12}$. Ao mesmo tempo, houve um forte esforço de obtenção de saldos da balança comercial, que passaram de US\$1,6 bilhões em 1981 para US\$ 6,5 bilhões em 1983 e

fatores que explicam os grandes déficits fiscal e comercial dos EUA, até hoje existentes (MACEDO et al., 1988).

7 Deflacionando esta taxa pelo preço das exportações não-petróleo dos paises em desenvolvimento, constata-se que a taxa real de juros saltou de $5,7 \%$ para $18,8 \%$ ao ano, na média, para os períodos 1975/79 e 1980/84, respectivamente (ZINI Jr., 1990).

8 Vide CRUZ (1984).

${ }^{9}$ CASTRO \& SOUZA, 1985, também defendem esse raciocinio.

10 ZINI JR., 1990.

11 WERNECK, 1986.

12 O salário real em São Paulo caiu 6,6\% em 1983 (BACEN, Programa Econômico, vol. 20). 
US\$ 13,1 bilhões em 1984. A obtenção dos crescentes superávits veio tanto da contenção das importações (que se reduziram em cerca de um terço), como da expansão das exportações (que se elevaram em $20 \%$ ).

A partir de 1984, ocorreu a recuperação do ritmo de atividade (o PIB cresceu 5,7\% nesse ano), calcada no crescimento das indústrias de bens exportáveis. CASTRO \& SOUZA (1985) defendem a tese de que foi a maturação dos investimentos efetuados durante o II PND que possibilitou a retomada do crescimento da economia, sem um correspondente aumento das importações. A rápida resposta de superávits da balança comercial só teria ocorrido devido à constituição de um parque industrial competitivo, quando do II PND.

A declaração da moratória mexicana, no segundo semestre de 1982, e a instabilidade originada pela Guerra das Malvinas precipitaram o colapso do sistema de financiamento das dívidas dos países em desenvolvimento, em especial junto aos credores privados. As transferências líquidas para o exterior, negativas até 1982 (o que significa entrada de recursos), tiveram seu sinal invertido de 1983 em diante, com o Brasil passando à condição de exportador líquido de capital ${ }^{13}$. O principal efeito da redução da poupança nacional, devido ao aumento das transferências para o exterior, foi a queda dos investimentos, cujo montante correspondia a cerca de $23 \%$ do PNB anual, até 1981, caindo para $19 \%$ em 1985.

Também se verificou mudança no aspecto fiscal da economia brasileira. A carga tributária líquida anual (cerca de 15\% do PIB até 1977), passou para menos de 10\% do PIB, de 1983 em diante. O déficit nominal do setor público ultrapassou

$13 \mathrm{O}$ hiato de recursos, financiado por poupança externa, era da ordem de $-5,92 \%$ do PNB em 1974. Passa para - $1,22 \%$ em 1978; -0,74\% em 1982; +2,54\% em 1983 e $+5,34 \%$ em 1985 (MACEDO et al., 1988). O ritmo de crescimento do endividamento externo diminuiu ao longo da década de $80(17,8 \%$ no período $1980 / 82 ; 8,6 \%$ no período $1983 / 85$ e $3,8 \%$ no período $1986 / 88$-- médias trienais). Porém, os desequilibrios do balanço de pagamentos persistiram, caindo de US $\$ 3,89$ bilhões para US $\$ 2,63$ bilhões, mas subindo para US $\$ 5,20$ bilhões, em média, para os mesmos três períodos. DORNBUSCH (1988) atribui parte das causas desse fato à adoção de uma política exageradamente expansionista. 
os $12 \%$ do PIB em 1981, chegando a $26 \%$ em 198514. O crescimento da dívida pública interna acompanhou essa dinâmica: $12,2 \%$ do PIB em 1981; 28,6\% em 198515.

Em suma, o que se observou foi um quadro de crise que se delineava devido a variáveis de natureza externa e interna. A nível externo, ocorreu o fim dos fluxos de poupança, que complementavam a poupança interna e permitiram o crescimento econômico da década de 70. Além disso, o Brasil passou a transferir parcelas significativas de seu produto para o exterior, intensificando-se a restrição externa. A nível interno, caíram os investimentos e as importações, não se expandiu a capacidade instalada (que, aparentemente, atingiu sua plena utilização em 1986) e a dívida interna exigia custos cada vez mais altos para ser refinanciada.

Grosso modo, pode-se diagnosticar a crise como advinda do esgotamento do padrão de financiamento da economia. De importadores líquidos de poupança, passamos a exportadores, face a um novo cenário financeiro internacional. A crise forçou o ajuste. E o início do processo de ajuste pode ser colocado à época da implantação do II PND, quando os investimentos foram realizados visando não só à substituição de importações, mas também à expansão da capacidade produtiva: a instalação de setores industriais que garantissem a autonomia doméstica quanto ao ciclo produtivo (indústrias de base e de bens intermediários), e a obtenção de vantagens comparativas industriais (que permitiram a geração de excedentes exportáveis de origem manufaturada e com maior valor agregado).

Estabelecido o quadro geral de reação da economia nacional frente à crise externa, interessa inquirir qual teria sido o comportamento individual dos diversos setores produtivos. Em particular, que papel desempenhou o setor agrícola? Como se

14 Utilizando o conceito de déficit operacional (no qual são excluídas as correções monetária e cambial), os valores são de $3,0 \%$ do PIB em 1979; 6,6\% em 1982; 1,6\% em 1984 e 5,7\% em 1987. O déficit público, além de pressionar os aumentos de taxas de juros e de inflação, estabelece uma dinâmica própria de auto-alimentação, pois também tende a cair a receita real dos impostos devido à diminuição do efeito "Oliveira-Tanzi" (MACEDO et al., 1988).

15 OLIVEIRA, 1985, in MACEDO et al. (1988). 
comportou esse setor diante das diretrizes gerais, de geração de saldos comerciais crescentes?

Destaquemos, pois, o setor agrícola dentre a estratégia global de ajuste aos problemas enfrentados com as contas externas. As exportações do setor contribuíram com cerca de um terço dos US\$ 33 bilhões exportados pelo Brasil em 198816. Quanto às importações, nota-se sensível decréscimo nos valores de importações tradicionais, como trigo e insumos, ao longo da década de 80. Contudo, importações eventuais de produtos primários (arroz, milho, feijão etc.), interferiram na consolidação dessa tendência decrescente das importações agrícolas ${ }^{17}$. Seria importante, então, analisar as razões que levaram a esse comportamento da balança comercial da agricultura.

A condução da política agrícola seguiu diretrizes concatenadas com a estratégia macroeconômica. Os objetivos setoriais preconizados para a agricultura eram: (1) a substituição das importações; (2) o incremento das exportações e (3) o pleno abastecimento interno, evitando pressões inflacionárias.

Quanto à substituição de importações do setor agropecuário, podemos distinguir três grupos de produtos. O primeiro grupo contempla importações de produtos agrícolas in natura para consumo direto ou como matérias-primas para a indústria. É o caso do trigo. As importações de trigo, sempre superiores a 4 milhões de toneladas anuais de 1980 a 1985, ficaram em 1,98 milhão de toneladas, em média, para o período 1986/88. Isso só foi possível devido ao notável crescimento da produção nacional, que atingiu a média anual de 5,76 milhões de toneladas, nesse último período.

16 Considerando o valor total dos semi-manufaturados e manufaturados de origem agrícola.

17 DELGADO \& FONSECA (1980) verificaram esse mesmo comportamento errático ocorrendo ao longo da década de 70. Encontraram saldos parciais do setor agrícola que se mostravam cada vez menores em termos relativos, com proporções sempre maiores de exportações sendo requeridas para cobrir as importações exigidas pelo próprio setor. Notam ainda que o valor das exportações cresce devido à subida de seus preços (com ligeiro declínio das quantidades), enquanto o preço das importações diminui, e seu quantum se eleva. 
Um segundo grupo de produtos é o das culturas energéticas, substitutivas do uso de petróleo, como a cana-de-açúcar. O Programa Nacional do Álcool (Proálcool) ${ }^{18}$, foi criado em 1975, com o propósito de aumentar a produção de etanol para usos carburante e químico. Dentro do necessário, o objetivo de substituir o uso do petróleo para fins carburantes pelo álcool foi atingido, em especial no que concerne ao transporte automotivo individual 19 .

O terceiro grupo de produtos substitutivos de importações está relacionado aos fatores de produção destinados ao setor agropecuário. O II PND conduziu, dentre seus objetivos, um programa de incentivo às indústrias nacionais de insumos ${ }^{20}$, que tiveram sua produção interna aumentada.

A participação relativa da agricultura nas exportações totais do Brasil caiu ao longo do período. Antes de 1978, mais da metade das exportações provinha do meio rural. No período 1987/88, ficaram em torno de um terço. O valor total (média anual, em valores correntes) passou de US\$2,75 bilhões no triênio 1971/73, para

18 O Proálcool foi criado pelo Decreto-Lei no 76593 , de 14/11/1975. A produção de cana para fins energéticos passa de $5 \%$ da produção total da cultura, em 1977, para 63\%, em 1985 (BARROS \& MANOEL, 1988).

19 Da produção nacional de automóveis de passeio, 63\% foi nas versões a álcool, em 1988 (ANFAVEA, 1989).

20 Em 1974 é criado o Programa Nacional de Fertilizantes e Calcário Agricola (PNFCA). Em 1985, a indústria nacional produziu $80 \%$ do nitrogênio $(N)$ e $97,6 \%$ do fósforo $(P)$ consumidos internamente (ALVES \& CONTINI, 1988). A partir de 1979, cessam as importações de tratores de rodas e colhedoras (SINFA VEA; Contador e Ferreira, 1984; in BARROS \& MANOEL,1988). As importações de inseticidas, fungicidas e herbicidas caem, respectivamente, cerca de $75 \%, 50 \%$ e $50 \%$, entre 1975 e 1985 , enquanto a produção nacional cresce de $25 \%, 181 \%$ e $3934 \%$, no mesmo período. Note-se que o consumo aparente de inseticidas foi o único que decresceu (44\%) (BARROS \& MANOEL, 1988). GUIMARÃES (1987), in BARROS \& MANOEL (1988), calcula que as importações (CIF) da agricultura cairam de US $\$ 4,7815$ bilhões em 1980 para US $\$ 2,4133$ bilhões em 1985 . $65 \%$ dessa queda refere-se a bens de capital $(1,5 \%)$ e a insumos $(63,5 \%)$ para a agricultura. 
US $\$ 9,24$ bilhões em 1986/88. O grau de abertura do setor agrícola manteve-se praticamente o mesmo: 0,17 (média anual), para os dois períodos considerados 21 .

Com efeito, o perfil das exportações agrícolas sofreu alterações ao longo dessas duas décadas. $\mathrm{O}$ aumento do valor das exportações deu-se graças à ampliação do número de produtos manufaturados derivados das commodities, com maior transformação industrial e maior valor adicionado 22. Aos produtos primários, tradicionais (café, cacau etc.) e não-tradicionais, somou-se o crescimento no uso de matérias-primas para o setor agroindustrial, que se instalou com maior vigor a partir do II PND (por exemplo, os complexos soja, citrus e madeira/papel).

Por fim, tratemos de abordar a questão do abastecimento interno ao longo das últimas duas décadas, tema bastante discutido ${ }^{23}$. MELO (1988) constata queda da quantidade per capita produzida de alimentos tradicionais (no período 1977/86, a taxa média anual de crescimento foi de $-1,35 \%$ e, para produtos de origem animal, essa taxa foi zero). DIAS (1990) encontra números crescentes para o valor da disponibilidade doméstica per capita de produtos domésticos e de produtos exportáveis.

Para as décadas de 70 e 80 , os estudos apontam, portanto, um aumento gradual do consumo interno de produtos de exportação. A queda do grau de abertura evidencia o incremento desse fenômeno a partir de 1983: a parcela da produção agrícola destinada à exportação caiu num passado recente. A esse fato adiciona-se a

21 O grau de abertura (Tabela 7, Apêndice 1), calculado por DIAS (1990), é considerado como a razão entre o valor exportado e o valor total da produção agropecuária nacional (somada a disponibilidade doméstica ao valor exportado; estão excluidos, porém, os produtos energéticos, como cana-de-açúcar).

22 BENEVENUTO (1989) aborda en passant esse assunto. Observando-se a pauta de exportações do Brasil, nota-se o aumento das participações relativas dos complexos soja, frutas, fumo e carnes, em detrimento dos complexos cacau, café e algodão, principalmente (para uma discussão mais detalhada, ver JANK, 1990).

23 Vide DIAS (1989); LOPES (1987); MELO (1985, 1988); REZENDE (1988, 1989, 1990). Como exemplo dessa polêmica, MELO e LOPES entendem que a crise de desabastecimento ocorrida no início da década de 80 foi resultado da adoção de politicas discriminatórias contra as culturas de alimentos. DIAS e REZENDE argumentam que as causas verdadeiras foram fenômenos meteorológicos e tomadas de decisão localizadas e em curto prazo revertidas. 
retomada do crescimento da produção de alimentos na década de $80^{24}$, indicando uma tendência a direcionamento da oferta agrícola para o suprimento da demanda interna.

Quanto aos preços dos produtos agropecuários, os dados mostram preços subindo na década de 70 e em queda na de $80^{25}$. Caem os preços das commodities no mercado externo, mas os preços internos apresentam-se melhores, com remunerações especialmente atraentes para os alimentos, de 1984 em diante. Isso levou muitos agricultores modernos a produzirem voltados para o consumo interno -- o que explica o aumento da disponibilidade doméstica de alimentos nessa década.

Os indícios são de que a agricultura atingiu os três objetivos a ela preconizados durante o processo de ajuste: substituição de importações, abastecimento interno e, em menor escala, aumento das exportações. Os principais fatores explicativos residem nas alterações que se vêm processando na produção rural, com o incremento significativo da atividade agroindustrial (o que se expressa, sobremaneira, na dinâmica das exportações do setor agrícola), e o esforço modernizante, estabelecido com maior vigor a partir da década de 70 .

A maior utilização de tecnologias e insumos modernos elevou as produtividades dos fatores terra e trabalho ${ }^{26}$. Parte do incentivo à modernização adveio

\footnotetext{
24 As enchentes de 1983 e a seca da safra 1985/86 foram responsáveis por sensiveis reduções das colheitas esperadas. Contudo, REZENDE (1990) mostra que há uma retomada do crescimento da produção de alimentos ao longo da década de 80 . No período $1979 / 88$, as taxas médias de crescimento da produção anual de arroz, feijão, mandioca e milho ficaram em $2,8 \%, 0,6 \%^{*},-0,3 \%{ }^{*}$ e $2,5 \%$, respectivamente ${ }^{*}$ indica que o coeficiente não é significativamente diferente de zero a nível de $5 \%$ teste bi-caudal).

25 É o resultado que consegue REZENDE (1990), utilizando índices para preços reais recebidos pelos agricultores, ano a ano. MELO (1988), quando calcula as taxas anuais médias de crescimento dos preços reais recebidos pelos produtores brasileiros durante o periodo 1966/1986, para 21 culturas principais, acha somente dois valores negativos (carne de frango e ovos) e oito zeros. Ressalte-se que as metodologias utilizadas são diferentes.

26 Sobre esse assunto, ver STOCK et alii (1984); MELO (1985); ALVES \& MARTINS (1988) e BARROS \& MANOEL (1988). MELO (1985) destaca a expansão de área cultivada, na década de 70, concentrada nas regiões dos Cerrados do Brasil Central, possibilitada graças à adoção de tecnologias modernas para o cultivo de grãos.
} 
da política de crédito rural subsidiado do final dos anos 70 e início dos anos 80 . Essa modemização garantiu a obtenção de safras recordes consecutivas, em que pese a redução da expansão da área utilizada, no período mais recente 27.

O desempenho do setor agrícola foi afetado mais intensamente pelas políticas macroeconômicas do que pelas políticas setoriais (como as políticas de preços mínimos, crédito rural, programas de fomento a certas culturas ou à adoção de tecnologias específicas). Diversos estudiosos voltaram-se a esse tópico, formando opinião majoritária a de que se trata de uma característica da intervenção governamental no Brasil o fato de que as medidas de natureza macroeconômica preponderam sobre as ações que visam a atingir especificamente o setor agrícola.

OLIVEIRA $(1984, a)$ mostra a transferência de recursos ocorrida da agricultura para a indústria via taxação implícita (com políticas fiscais, cambiais e de juros), acarretando em divergências dos termos de troca intersetoriais, no período 19501974. OLIVEIRA $(1984, b)$ retorna ao tema, dizendo que também entre subsetores do meio agropecuário houve essa transferência. $\mathrm{O}$ crédito rural subsidiado destinou-se às culturas mais intensivas em tecnologias modernas, quais sejam, as lavouras de produtos exportáveis.

BRANDÃO \& CARVALHO (1989), in BRANDÃO (1989), comparam a transferência líquida de recursos para a agricultura, como porcentagem da renda agrícola. Na média, para o período 1966-1983, esse valor fica em torno de 5,5\%, incluindo crédito, e $-3,5 \%$, excluindo crédito, o que também evidencia a apropriação de renda pelos setores mais beneficiados pelo crédito rural.

BARROS (1986) analisa, a nível agregado, a influência de algumas variáveis macroeconômicas sobre o comportamento dos preços agropecuários reais em

27 Segundo o IBGE, in WORLD BANK (1988), a taxa média anual de expansão na área utilizada (disponivel para o plantio) foi de $2,7 \%$ para o período $1975 / 80$ e de $0,4 \%$ para o período $1980 / 85$. WORLD BANK destaca ainda que as doze principais culturas respondem por $98 \%$ da terra total cultivada. 
quatro níveis de mercado (produtor, atacado, indústria e consumidor), para o período 1969/85. Os resultados são compatíveis com a hipótese de que a redução do hiato do produto $^{28}$ leva os preços industriais a crescerem mais que os preços agrícolas, cujo crescimento é limitado pelo mercado externo.

O trabalho de BRANDÃO (1989, opus citado) analisa a natureza da proteção à agricultura no Brasil ${ }^{29}$. São calculadas as taxas de proteção nominal (políticas que afetam diretamente o produto) e as taxas de proteção total (incluem o efeito das políticas de caráter macroeconômico sobre o produto em questão). As lavouras enfocadas são em número restrito (o que faz com que o raciocínio desenvolvido a partir dos resultados seja visto com cautela): algodão, soja, milho, arroz e trigo. A conclusão do autor é de que "o Brasil discrimina contra as exportações agrícolas, dando um tratamento mais favorável aos produtos alimentares. Os instrumentos de política macroeconômica tem efeito predominante (...) [sobre] as chamadas políticas diretas, no que se refere à taxação do setor. (...) $\mathrm{O}$ efeito final quase sempre mostra taxação generalizada" (p.281).

Um dos trabalhos mais abrangentes acerca do efeito de diversas políticas macroeconômicas sobre a agricultura é o de LOPES (1989). Nesse estudo, é definida a taxa de câmbio real -- a relação de preços entre os produtos transacionados no mercado externo e os produtos de consumo interno, uma variável importante na determinação da lucratividade das exportações agrícolas. Estas, por sua vez, sempre

28 O hiato do produto é definido como a diferença entre o produto efetivo e o produto potencial do país, para um dado periodo. Quanto maior o hiato, menor o nivel de utilização da capacidade instalada.

29 Uma discussão sobre a taxação via distorção dos preços relativos de produtos agricolas comercializáveis internacionalmente é encontrada em WORLD BANK (1986) e em JOHNSON (1988). Trata-se de um tema bastante atual -- a retirada das barreiras protecionistas e o fim dos subsídios ao setor agrícola das economias desenvolvidas. O confronto ocorre não só quando Norte e Sul se reúnem para discutir, quando, por exemplo, das rodadas do Acordo Geral de Comércio e Tarifas (Gatt), mas também entre as próprias nações do Primeiro Mundo. Vide, a respeito, as negociações acerca do estabelecimento da "Europa Unificada", quando a questão agrícola constituiu-se em um dos pontos mais delicados (SOARES, 1988; SOARES, 1989). 
foram um fator muito significativo na composição da rentabilidade da agricultura brasileira.

Lopes discute, teoricamente, os efeitos de diversas políticas -- de proteção à indústria, de reservas e endividamento externo, de comércio agrícola, de gasto público (política fiscal) e de estabilização macroeconômica -- sobre a taxa de câmbio real e sobre a estrutura de incentivos e lucratividade da agricultura. Discute também os efeitos das mudanças nos termos de troca externos e de um choque autônomo na balança comercial. Dois modelos são desenvolvidos e testados empiricamente para o Brasil.

O primeiro modelo considera a taxa de câmbio real como variável dependente. Os resultados indicam significância estatística para as variáveis referentes a política monetária (crescimento da oferta da moeda), política fiscal (expansão do déficit público), política comercial (impostos de exportação) e termos de troca externos (relação entre preços dos produtos exportados e os preços dos produtos importados), todas elas apresentando correlação negativa com a taxa de câmbio real. Isto é, a elevação dos valores dessas variáveis ao longo do período considerado (1948-1986) teve o efeito de reduzir a taxa real de câmbio, implicando em queda da rentabilidade das exportações agrícolas.

O segundo modelo analisa os efeitos das políticas macroeconômicas sobre os preços setoriais. A variável dependente é a razão entre os preços dos produtos agrícolas de exportação (regressões com e sem café são estimadas) e os bens domésticos. As estimativas do modelo respaldam a hipótese de que as políticas fiscais, gastos do governo (contemporaneamente ou com defasagem de um período) e déficit público causam impacto negativo sobre os preços dos produtos agrícolas de exportação. A variável PIB real per capita tem um impacto positivo na taxa de câmbio real, provavelmente devido à grande participação de produtos com elevadas elasticidadesrenda da demanda (soja, carne, algodão) no mix de exportações. 
Dadas as características da economia nas últimas duas décadas, conclui-se que as políticas macroeconômicas causaram constante perda de rentabilidade do setor agrícola através da redução de taxa de câmbio real, neutralizando, inclusive, as políticas setoriais específicas para a agropecuária. LOPES (1987) afirma enfaticamente que "as políticas comercial e macro reduziram a contribuição da agricultura ao crescimento e ao balanço de pagamentos, sobre ter tornado o país dependente de importações de produtos que outrora era grande exportador", referindo-se, neste último ponto, ao comportamento das culturas de algodão, arroz e milho, de 1973 em diante.

A lacuna da literatura quanto à inserção do setor agrícola no processo de ajuste refere-se a uma abordagem direta sobre o principal indicador da restrição externa -- o saldo do balanço de pagamentos. Especificamente, falta uma análise mais minuciosa sobre o saldo em transações correntes, que contemple o ajuste sob os aspectos de demanda e oferta intemas agregadas (o que pode ser extraído dos números da balança comercial) e a influência de fatores a nível internacional, como a elevação das taxas de juros e a alteração dos termos de troca.

Nessa perspectiva, alguns estudos procuraram verificar, através de métodos quantitativos, a relação entre choques externos e políticas econômicas governamentais, ao longo dos processos de ajuste do balanço de pagamentos. São pesquisas que objetivavam compreender (e prever) o comportamento global da economia, sem descer ao nível de desempenho setorial.

BALASSA et alii (1981) desenvolveram metodologia aplicada a nove países em desenvolvimento, para o período 1974-1977. Foram considerados os efeitos, sobre o balanço de pagamentos, de choques externos (variações nos termos de troca e no volume de exportações), e as respostas de políticas econômicas internas (financiamentos externos líquidos adicionais, promoção de exportações, substituição de importações e redução das taxas de crescimento econômico). 
Em outros dois trabalhos (BALASSA, 1981; BALASSA \& McCARTHY, 1984), conclui-se que, para os períodos 1974/78 e 1979/82, as perdas causadas pela deterioração dos termos de troca são as principais responsáveis pelo aumento do déficit em transações correntes. Segundo os autores, isso se contrapunha à idéia corrente de que a recessão mundial e o protecionismo dos países industrializados eram os responsáveis pela deterioração das contas externas dos países em desenvolvimento.

Essas conclusões coadunam com as extraídas por BACHA (1984 e 1985), que seguiu metodologia similar à de Balassa, com pequenas alterações entre os dois trabalhos considerados.

O estudo de 1984 utiliza um modelo de simulação simples com dois hiatos, para investigar as perspectivas econômicas do Brasil até 1989. Há três grupos de fatores explicativos: choques externos; ônus da dívida externa e políticas internas. Tomase por base o período 1973-1983, dividido em dois: 1973/78 e 1978/83. Para o primeiro subperíodo, o quadro detectado por Bacha "(...) é o de uma economia em desenvolvimento que decidiu não provocar uma recessão como meio de lidar com a adversidade externa. (...) [Depois de 1975] o país passou a ajustar o balanço de pagamentos através de uma substituição significativa de importações de bens de capital e de outras importações, que não o petróleo" (p.591).

Quanto ao subperíodo 1978/83, o autor conclui que "a deterioração das relações de troca responde pela parte mais importante do choque total, enquanto aumento das taxas de juros e retarde do crescimento do comércio mundial dividem a responsabilidade pelas perdas remanescentes" (p.593). A reação doméstica foi forte (porém tardia -- a partir de 1980, principalmente), com a diminuição do crescimento e a expansão da competitividade externa. Essa reação, segundo Bacha, foi insuficiente para manter a credibilidade externa do país, após os acontecimentos de 1982. 
No trabalho de 1985, Bacha procede à construção de dois sistemas contábeis, visando a decompor a variação da conta corrente do balanço de pagamentos de um país devedor entre fatores de origem externa -- tais como variações das relações de troca, choques de juros e flutuações do comércio mundial -- , e de origem interna -tais como pressões da demanda doméstica e mudanças na competitividade dos bens e serviços comerciáveis. Aplica-se um desses esquemas aos dados dos balanços de pagamentos de dez países latino-americanos no período 1978/82, e os resultados indicam não ser possível resumir numa só expressão, como "choques externos" ou "gastos excessivos", as razões da deterioração das contas externas desses países.

As pesquisas de Bacha e Balassa procuraram quantificar o impacto das variáveis internas e externas sobre os desequilíbrios no balanço de pagamentos dos países endividados, nos anos 70 e 80 . Enfocaram a economia desses países como um todo. Ao contrário, a indagação que se faz no presente trabalho visa, justamente, verificar a participação de cada setor da economia sobre os desequilíbrios e ajustes efetuados no balanço de pagamentos.

Conforme observado anteriormente, o diagnóstico é de que o setor agrícola respondeu aos objetivos do ajuste. De um modo geral, ocorreu a substituição de importações, a garantia do abastecimento interno, e houve o esforço exportador. Contudo, aconteceu alteração qualitativa da pauta de exportações, comportamento particular quanto ao abastecimento interno (consumo de produtos não-tradicionais, por exemplo) e trajetória própria do mercado internacional de produtos agrícolas, tanto no que tange a preços como a tipos de produtos demandados.

A dinâmica própria do setor agrícola ao longo do período 1973 a 1988, seja quando voltado para o mercado interno ou quando orientado para exportação, enseja o enfoque da economia brasileira dentro de um modelo dual, considerando-se um setor agrícola e um setor não-agrícola. A contribuição de cada setor ao ajuste será quantificada utilizando-se uma metodologia desenvolvida a partir dos modelos propostos por Balassa e Bacha, a ser explicitada no capítulo seguinte. 


\section{METODOLOGIA}

\subsection{Desenvolvimento da metodologia}

O desenvolvimento metodológico segue a linha adotada por BALASSA (1981a, 1981b, 1984) para uma série de estudos realizados pelo Banco Mundial. BACHA (1984, 1985), emprega metodologia semelhante para trabalhos mais aprofundados sobre o Brasil e a América Latina.

Ambos os autores tinham por objetivo mensurar a influência de alguns fatores (que serão detalhados ao longo desta seção) sobre o comportamento do saldo em transações correntes do balanço de pagamentos.

O objetivo deste trabalho é quantificar a participação dos setores agrícola e não-agricola no saldo em transações correntes do balanço de pagamentos. A seguir, expõe-se um modelo contábil que busca essa quantificação, partindo de estrutura utilizada pelos autores citados acima.

Das contas nacionais, sabemos que o déficit do balanço de pagamentos em conta corrente (D) é igual à diferença entre os gastos dos residentes (em consumo mais investimento do setor privado mais gasto do governo), (E), e a renda nacional, ( $\left.\mathbf{Y}^{\prime}\right)$, acrescida das transferências do exterior, (T) (todos os valores estão em preços correntes), ou seja:

$$
\mathbf{D}=\mathbf{E}-\mathbf{Y}^{\prime}-\mathbf{T}
$$


O gasto dos residentes em preços correntes, (E), é igual à soma dos gastos em consumo (C) e investimento (I) (aqui não importa distinguir se o gasto é efetuado pelo setor privado ou pelo setor público):

$$
\mathbf{E}=\mathbf{C}+\mathbf{I}
$$

A renda nacional, $\mathbf{Y}^{\prime}$, é igual à diferença entre a renda doméstica, $\mathbf{Y}, \mathrm{e}$ o serviço líquido de fatores, $\mathbf{V}$.

$$
\mathbf{Y}^{\prime}=\mathbf{Y}-\mathbf{V}
$$

A renda doméstica, $\mathbf{Y}$, é uma identidade básica que pode ser escrita em termos dos componentes da demanda, como a soma das despesas de consumo e de investimento, com o saldo líquido da balança comercial, $\mathbf{M}-\mathbf{X}$, onde $\mathbf{M}$ representa $\mathbf{o}$ valor das importações de bens e serviços de não-fatores, e $\mathbf{X} \mathbf{o}$ valor das exportações de bens e serviços de não-fatores, ambos a preços correntes. A renda doméstica, $\mathbf{Y}$, seria representada da seguinte forma:

$$
\mathbf{Y}=\mathbf{C}+\mathbf{I}-(\mathbf{M}-\mathbf{X})
$$

Substituindo-se (2), (3) e (4) em (1), e procedendo-se aos devidos desenvolvimentos algébricos, teríamos a seguinte expressão para o déficit do balanço de pagamentos em conta corrente, $\mathbf{D}$ :

$$
\mathbf{D}=\mathbf{M}+\mathbf{V}-\mathbf{X}-\mathbf{T}
$$


Devemos decompor as magnitudes a preços correntes em índices de preços e de quantidades. Seja $\mathbf{J}$ o índice de quantum das importações e $\mathbf{P}_{\mathbf{m}}$ o respectivo índice de preços. Então:

$$
\mathbf{M}=\mathbf{P}_{\mathbf{m} \cdot \mathbf{J}}
$$

Seja $\mathbf{Z}$ o índice de quantum das exportações e $\mathbf{P}_{\mathbf{X}}$ o respectivo índice de preços. Então:

$$
\mathbf{X}=\mathbf{P}_{\mathbf{x}} \cdot \mathbf{Z}
$$

Considere-se ainda que o serviço líquido de fatores, $\mathbf{V}$, é subdividido em duas parcelas: $\mathbf{V}_{\mathbf{i}}$, que indica os juros líquidos pagos ao exterior, e $\mathbf{V}_{\mathbf{d}}$, que são as outras rendas líquidas de capitais pagas ao exterior, ou seja:

$$
\mathbf{V}=\mathbf{V}_{\mathbf{i}}+\mathbf{V}_{\mathbf{d}}
$$

$\mathrm{O}$ termo $\mathbf{V}_{\mathbf{i}}$ pode expressar-se como o produto de uma taxa de retorno, $\mathbf{r}$, pelo valor da dívida externa líquida do país, $\mathbf{K}$ :

$$
\mathbf{V}_{\mathbf{i}}=\mathbf{r} \cdot \mathbf{K}
$$

Utilizando-se (6), (7), (8) e (9), podemos reescrever (5) como se segue:

$$
\mathbf{D}=\mathbf{P}_{\mathbf{m}} \cdot \mathbf{J}+\mathbf{r} \cdot \mathbf{K}+\mathbf{V}_{\mathbf{d}}-\mathbf{P}_{\mathbf{x}} \cdot \mathbf{Z}-\mathbf{T}
$$

Os termos $\mathbf{P}_{\mathbf{m}}$.J e $\mathbf{P}_{\mathbf{x}} . \mathbf{Z}$ serão decompostos para os setores agrícola e não-agrícola, a fim de se atender aos objetivos deste trabalho. 
Convencione-se que o sobrescrito $\left({ }^{a}\right)$ refere-se ao setor agrícola e o sobrescrito $\left(\mathbf{(}^{\mathbf{n}}\right)$ indica o setor não-agrícola.

Sejam $\mathbf{J}^{\mathbf{a}}$ e $\mathbf{J}^{\mathbf{n}}$ os índices de quantum das importações referentes ao setor agrícola (o que inclui insumos importados) e não-agrícolas, respectivamente, e $\mathbf{P}_{\mathbf{m}}{ }^{\mathbf{a}}$ e $\mathbf{P}_{\mathbf{m}} \mathbf{n}$ os correspondentes índices de preços. Então:

$$
\mathbf{P}_{\mathbf{m}} \cdot \mathbf{J}=\mathbf{P}_{\mathbf{m}} \mathbf{a}^{. \mathbf{J}} \mathbf{a}+\mathbf{P}_{\mathbf{m}} \mathbf{n}_{. \mathbf{J}} \mathbf{n}
$$

Sejam $\mathbf{Z}^{\mathbf{a}}$ e $\mathbf{Z}^{\mathbf{n}}$ os índices de quantum das exportações agrícolas e nãoagrícolas, respectivamente, e $\mathbf{P}_{\mathbf{x}}{ }^{\mathbf{a}}$ e $\mathbf{P}_{\mathbf{x}}{ }^{\mathbf{n}}$ os correspondentes índices de preços. Então:

$$
\mathbf{P}_{\mathbf{x}} \cdot \mathbf{Z}=\mathbf{P}_{\mathbf{x}} \mathbf{a} \cdot \mathbf{Z}^{\mathbf{a}}+\mathbf{P}_{\mathbf{x}} \mathbf{n} \cdot \mathbf{Z}^{\mathbf{n}}
$$

Substituindo (11) e (12) em (10), teremos:

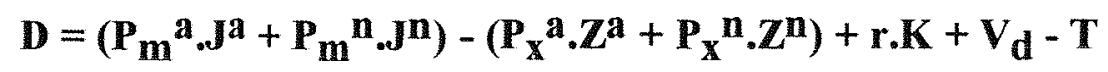

Dividiremos a equação (13) pelo valor do produto nacional, $\mathbf{Y}^{\prime}$, que supomos ser igual ao produto do deflator implícito do PIB, $\mathbf{P}_{\mathbf{y}}$, pelo produto nacional a preços constantes, $\mathbf{U}^{\mathbf{3 0}}$ :

$$
\mathbf{Y}^{\prime}=\mathbf{P}_{\mathbf{y}} \cdot \mathbf{U}^{\prime}
$$

\footnotetext{
${ }^{30}$ De acordo com BACHA (1985), seria apropriado dividir a equação (13) pelo valor do produto potencial, $\mathbf{Y}^{\star}$. Em princípio, $\mathbf{Y}^{\star}$ é determinado de uma forma independente do saldo do balanço de pagamentos em conta corrente. Trata-se, pois, de um divisor adequado para avaliar a importância relativa de um eventual déficit externo medido em relação ao potencial produtivo de um país. Entretanto, não há estimativas uniformes desse valor para um período de tempo tão longo como o que esta pesquisa aborda (19 anos).
} 
Dividindo (13) por (14) e introduzindo as relações entre o quantum das importações agrícolas e não-agrícolas, e o gasto doméstico real em produtos de origem agrícola ( $\left.\mathbf{A}^{\mathbf{a}}\right)$ e não-agrícola $\left(\mathbf{A}^{\mathbf{n}}\right), \mathbf{J}^{\mathbf{a}} / \mathbf{A}^{\mathbf{a}}$ e $\mathbf{J}^{\mathbf{n}} / \mathbf{A}^{\mathbf{n}}$; entre o quantum das exportações agrícolas e o volume do comércio mundial de produtos agrícolas ( $\left.\mathbf{W}^{\mathbf{a}}\right), \mathbf{Z}^{\mathrm{a}} / \mathbf{W}^{\mathrm{a}}$; e entre o quantum das exportações não-agrícolas e o volume do comércio mundial de produtos não-agrícolas $\left(\mathbf{W}^{\mathbf{n}}\right), \mathbf{Z}^{\mathbf{n}} / \mathbf{W}^{\mathbf{n}}$, obtemos:

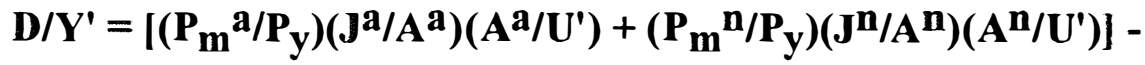

$$
\begin{aligned}
& {\left[\left(\mathbf{P}_{\mathbf{x}} \mathbf{a} / \mathbf{P}_{\mathbf{y}}\right)\left(\mathbf{Z}^{\mathbf{a}} / \mathbf{W}^{\mathbf{a}}\right)\left(\mathbf{W}^{\left.\mathbf{a} / \mathbf{U}^{\prime}\right)}+\mathbf{P}_{\mathbf{x}} \mathbf{n} / \mathbf{P}_{\mathbf{y}}\right)\left(\mathbf{Z}^{\mathbf{n}} / \mathbf{W}^{\mathbf{n}}\right)\left(\mathbf{W}^{\mathbf{n}} / \mathbf{U}^{\prime}\right)\right]+\mathbf{r K} / \mathbf{Y}^{\prime}+} \\
& \mathbf{V}_{\mathbf{d}^{\prime}} / \mathbf{Y}^{\prime}-\mathbf{T} / \mathbf{Y}^{\prime}
\end{aligned}
$$

A equação (15) é a expressão básica para a decomposição das variações da conta corrente em três tipos de termos: choques externos (1), outras variáveis externas (2) e políticas domésticas (3).

Os chogues externos (1) podem ser subdivididos em três categorias: relações de troca [a], juros [b] e nível do comércio mundial [c].

As outras variáveis externas (2) compreendem três itens -- acúmulo da dívida externa líquida [a], outras rendas de capitais [b], e transferências do exterior [c].

A política doméstica (3) comporta dois tipos de efeito: gasto doméstico [a] e competitividade externa [b] (subdividida em conteúdo de importações no gasto doméstico, $\mathbf{J} / \mathbf{A}$, e parcela das exportações no comércio mundial, $\mathbf{Z} / \mathbf{W}$ ).

Mais especificamente, considere-se a diferença da razão $\mathbf{D} / \mathbf{Y}^{\prime}$ entre dois anos quaisquer. Aplicando o operador de diferenças, $\underline{d}$, na equação (15), obtemos a seguinte expressão: 


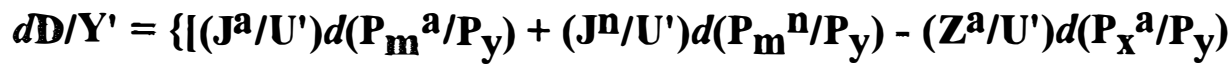

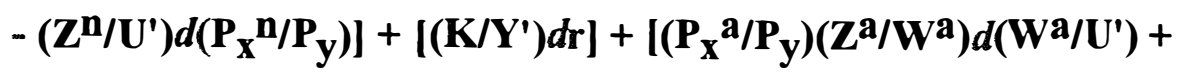

$$
\begin{aligned}
& \left.\left.\left(\mathbf{P}_{\mathbf{x}} \mathbf{n} / \mathbf{P}_{\mathbf{y}}\right)\left(\mathbf{Z}^{\mathbf{n}} / \mathbf{W}^{\mathbf{n}}\right) d\left(\mathbf{W}^{\mathbf{n}} / \mathbf{U}^{\prime}\right)\right]\right\}+\left\{\mathbf{r} d\left(\mathbf{K} / \mathbf{Y}^{\prime}\right)+d\left(\mathbf{V}_{\mathbf{d}^{\prime}} / \mathbf{Y}^{\prime}\right)-d\left(\mathbf{T} / \mathbf{Y}^{\prime}\right)\right\}+
\end{aligned}
$$

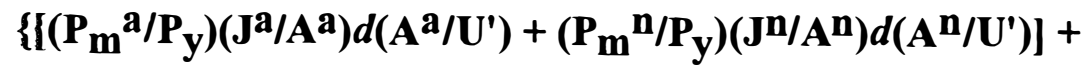



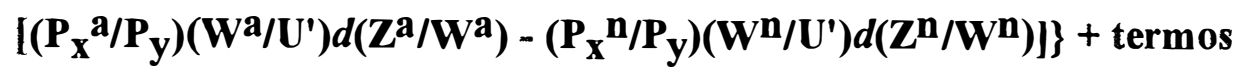

$$
\begin{aligned}
& \text { de } 2^{a} \text { e } 3^{a} \text {. ordem } 31
\end{aligned}
$$

Ou seja, à parte os termos de interação, decompõe-se a variação da razão entre o déficit em conta corrente e a renda nacional em três termos básicos -- o primeiro, compreendendo os choques externos $\{1\}$; o segundo, as outras variáveis externas $\{2\}$ e o terceiro referindo-se ao impacto das políticas domésticas $\{3\}$.

Três tipos de choques externos $\{1\}$ são identificados por colchetes. $O$ primeiro é o efeito das variaç̃es das relações de troca [a]; o segundo, o efeito das variações das taxas de juros [b] e o terceiro tratando-se do efeito da variação do comércio mundial de produtos agrícolas e não-agrícolas [c] (medida como proporção do nível da renda nacional real).

Dentre as outras variáveis externas $\{2\}$, sobressai, para fins de análise, 0 impacto das variações do endividamento externo [a], K/Y'. As outras rendas de capital [b] são encaradas como resíduo da balança de serviços, excluído o serviço da dívida. As transferências unilaterais [c] (aqui empregadas no lugar das transferências do exterior) constituem-se de valores ínfimos, em termos comparativos às demais variáveis.

As políticas domésticas $\{3\}$ são divididas em dois tipos. O primeiro refere-se a variações no gasto doméstico [a] (em produtos de origem agrícola e nãoagrícola). O segundo tipo de políticas domésticas concerne a variações na

\footnotetext{
31 Considere-se uma série de Taylor, com aproximação de primeira ordem. O resíduo será creditado à não-computação dos termos até a enésima ordem.
} 
competitividade externa [b], subdividida em mudanças do conteúdo das importações no gasto doméstico e variações da parcela das exportações no comércio mundial, em termos reais (ambas discriminando os valores pertinentes ao setor agrícola e ao setor nãoagrícola).

Note-se, na equação (16), a necessidade de se fixar um período de referência para calcular os fatores que multiplicam os termos precedidos pelo operador $d$. $O$ período escolhido será aquele que tender a minimizar o valor dos termos de $2 \underline{a}$ e $3 \underline{a}$ ordem (os quais são indicados pela expressão "resíduo não explicado" nas tabelas de resultados).

\subsection{Base de dados}

Os dados utilizados na aplicação da equação (16) estão listados no Apêndice 1. A economia está dividida em dois setores: o "agrícola" e o "não-agrícola". Essa divisão baseou-se no critério adotado pelo Gatt $(1989)^{32}$.

Importações agrícolas são consideradas aquelas destinadas à utilização pelo próprio setor (como insumos) ou que sejam produtos agropecuários, in natura ou com algum grau de transformação industrial, tanto para consumo direto, quanto matériasprimas para outros ramos de atividade.

Os valores coletados em dólares americanos foram transformados em moeda nacional utilizando-se a taxa média de câmbio anual, conforme consta do Boletim do Banco Central (BACEN).

$32 \mathrm{O}$ Gatt divide os produtos agrícolas em dois grandes grupos: alimentos e matéria-primas. Alimentos: alimentos e animais vivos; bebidas e tabaco; gorduras e óleos de origem animal e vegetal; sementes e frutos de oleaginosas (SITC Rev. 3, seções 0,1,4 e divisão 22). Matérias-primas: peles e couros brutos; borracha crua (incluindo sintética e reciclada); cortiça e madeira; polpa e resíduos de papel; fibras têxteis e seus tecidos; produtos brutos de origem animal e vegetal, n.e.s. (SITC Rev. 3, divisões 21, 23, 24, 25, 26, 29). 
Convenciona-se utilizar a letra $\underline{\text { a }}$, sobrescrita, para indicar que a variável refere-se ao setor agrícola. A letra $\underline{\mathbf{n}}$, sobrescrita, indica que a variável diz respeito ao setor não-agrícola. Por exemplo, o símbolo $\mathrm{J}^{\mathbf{a}}$ indica as importações de bens de origem agrícola e insumos para a agricultura em moeda nacional constante. $\mathrm{O}$ símbolo $\mathrm{J}^{\mathbf{n}}$ referese às importações de bens de origem não-agrícola, exceto insumos para a agricultura, em moeda nacional constante.

Segue-se a especificação de cada uma das variáveis que fazem parte da equação (16).

$\mathbf{M}=$ importações de bens em moeda nacional a preços correntes -valores extraídos da Coordenadoria de Informações Econômicas do Ministério da Fazenda (CIEF), do BACEN e da Carteira de Comércio Exterior (CACEX).

$\mathbf{X}=$ exportações de bens em moeda nacional a preços correntes -valores extraídos da CIEF, do BACEN e da CACEX.

$\mathbf{J}=$ importações de bens em moeda nacional constante -- valores calculados pelo autor.

$\mathbf{Z}=$ exportações de bens em moeda nacional constante -- valores calculados pelo autor.

$\mathbf{P}_{\mathbf{m}} \mathbf{a}=$ índice dos preços domésticos das importações agrícolas $(1971=$ $1,0)$-- valor calculado a partir de $\mathbf{M}^{\mathbf{a}}=\mathbf{P}_{\mathbf{m}}{ }^{\mathbf{a}} . \mathbf{J}^{\mathbf{a}}$.

$\mathbf{P}_{\mathbf{m}} \mathbf{n}=$ índice dos preços domésticos das importações não-agrícolas $(1971=1,0)$-- valor calculado a partir de $\mathbf{M}^{\mathbf{n}}=\mathbf{P}_{\mathbf{m}^{\mathbf{n}}} \cdot \mathbf{J}^{\mathbf{n}}$.

$\mathbf{P}_{\mathbf{x}} \mathbf{a}=$ índice dos preços domésticos das exportações agrícolas $(1971=$ $1,0)$-- valor calculado a partir de $\mathbf{X}^{\mathbf{a}}=\mathbf{P}_{\mathbf{x}} \mathbf{a} \cdot \mathbf{Z}^{\mathbf{a}}$. 
$\mathbf{P}_{\mathbf{x}} \mathbf{n}=$ índice dos preços domésticos das exportações não-agrícolas $(1971=1,0)$-- valor calculado a partir de $\mathbf{X}^{\mathbf{n}}=\mathbf{P}_{\mathbf{X}}{ }^{\mathbf{n}} \cdot \mathbf{Z}^{\mathbf{n}}$.

$\mathbf{D}=$ déficit em transações correntes, em moeda nacional a preços correntes -- extraído do Balanço de Pagamentos (BACEN).

$\mathbf{A}=$ gasto doméstico bruto em moeda nacional a preços constantes.

$\mathbf{A}^{\mathbf{a}}=$ gasto doméstico bruto referente ao setor agrícola, em moeda nacional constante -- importações em produtos agrícolas somadas ao valor da disponibilidade doméstica da produção agropecuária nacional, em preços constantes (valor extraído de DIAS, 1990).

$\mathbf{A}^{\mathbf{n}}=$ gasto doméstico bruto referente ao setor não-agrícola, em moeda nacional constante -- valor calculado através da diferença entre $\mathbf{A}$ e $\mathbf{A}^{\mathbf{a}}$.

$\mathbf{W}^{\mathbf{a}}=$ índice do Gatt (General Agreement on Tariffs and Trade) para $\mathbf{0}$ volume das exportações agrícolas mundiais, ano-base 1971.

$\mathbf{W}^{\mathbf{n}}=$ índice do volume das exportações não-agrícolas mundiais, anobase 1971 (calculado pelo autor, com base nos índices do Gatt).

$\mathbf{T}=$ transferências unilaterais em moeda nacional a preços correntes -extraído do Balanço de Pagamentos.

$\mathbf{V}=$ serviço líquido de fatores pagos ao exterior em moeda doméstica a preços correntes -- extraído do Balanço de Pagamentos.

$\mathbf{V}_{\mathbf{d}}=$ outras rendas de capital, em moeda nacional a preços correntes -valor calculado através da equação (8).

$\mathbf{V}_{\mathbf{i}}=$ juros líquidos pagos ao exterior em moeda nacional a preços correntes -- valor extraído do Balanço de Pagamentos (BACEN). 
$\mathbf{r}=$ taxa de juros -- valor calculado implicitamente como a razão entre os pagamentos de juros no ano $t$ e a dívida registrada no final do ano $t-1$ (equação (9)).

$$
\mathbf{K}=\text { dívida externa líquida ao final do ano } \boldsymbol{t}-1 \text {, expressa em moeda }
$$
nacional a preços correntes -- extraído da Tabela 6.3.7 do Boletim do BACEN.

$$
\mathbf{Y}^{\prime}=\text { produto nacional bruto em moeda nacional a preços correntes -- }
$$
item 6.5 das Contas Nacionais.

$\mathbf{U}^{\prime}=$ produto nacional bruto em moeda nacional a preços de 1972 -valor calculado a partir da equação (14).

$$
\mathbf{P}_{\mathbf{y}}=\text { deflator implícito do PIB }(1971=1,0) \text {-- Quadro } 5 \text { das Contas }
$$

Nacionais. 


\section{RESULTADOS E DISCUSSĀO}

\subsection{Das variáveis do modelo de decomposição.}

As Tabelas 1 e 3 contêm os valores das variáveis utilizadas na decomposição da equação (15). As Tabelas 2 e 4 mostram as diferenças de cada variável em relação aos respectivos anos-base. Os resultados da decomposição do saldo em transações correntes do balanço de pagamentos encontram-se listados nas Tabelas 5 a 7 . As Tabelas 8 e 9 destacam a participação do setor agrícola. A análise do comportamento de cada variável ao longo do tempo, comparando-se as bases de preços 1971-73 e 198688, utiliza os dados das Tabelas 1 e 3 e das Figuras 1 a 16.



Figura 1. Saldo em transações correntes do balanço de pagamentos em relação ao PNB. 

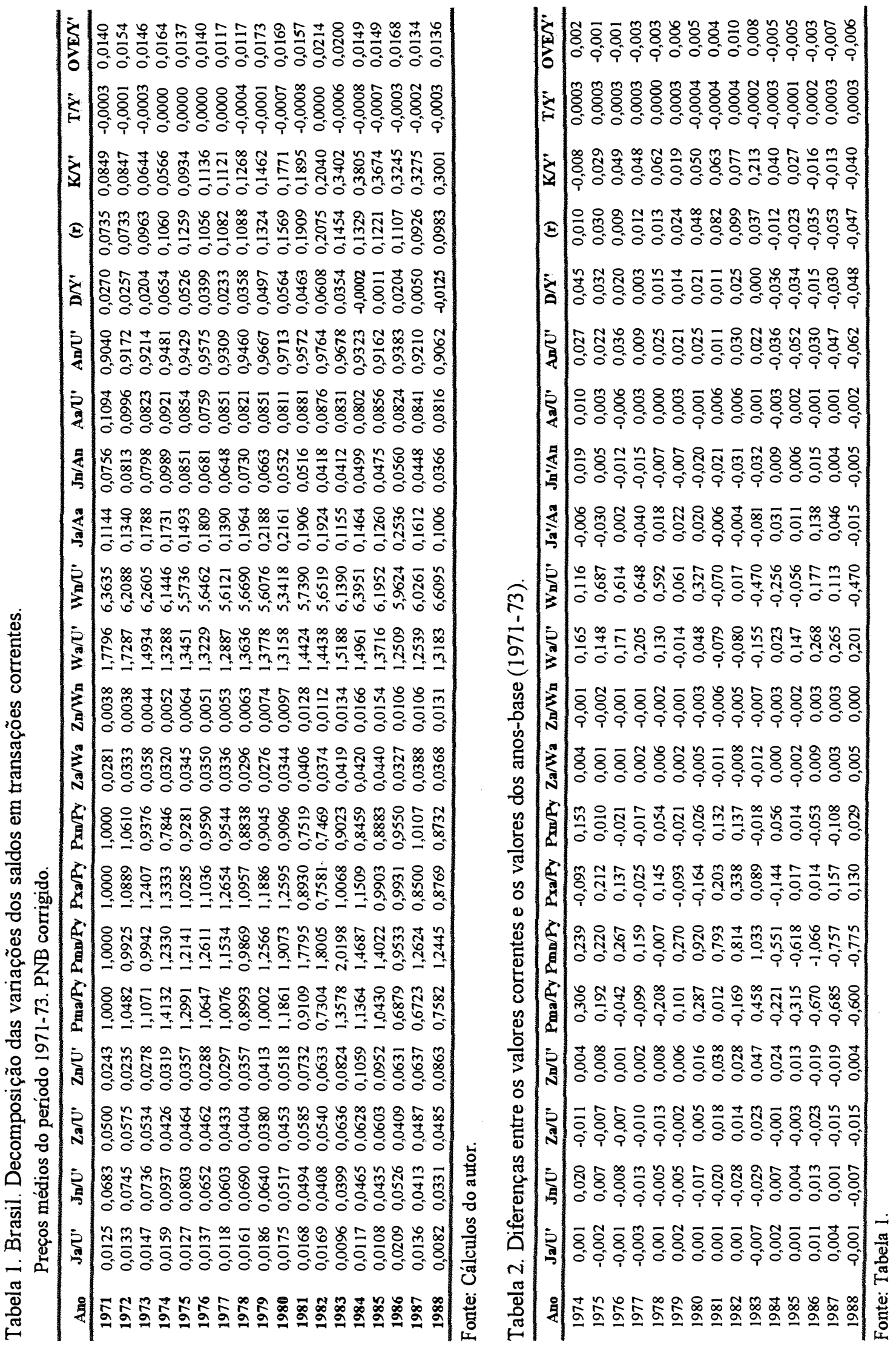

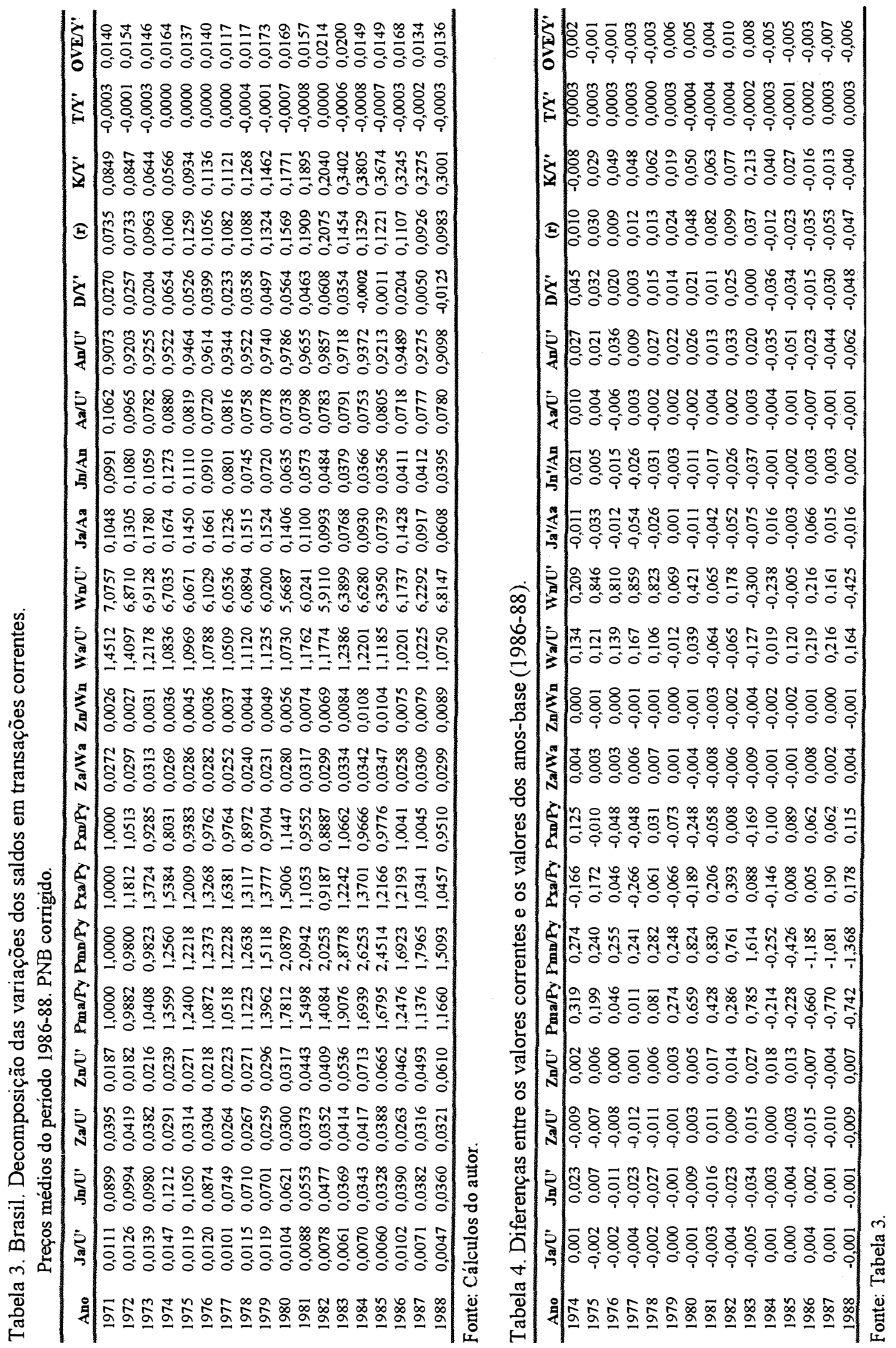
A Figura 1 mostra que o saldo em transações correntes (D/Y') aumenta acentuadamente de $1973(0,0204)$ para $1974(0,0654)$, retornando ao nível de cerca de $3 \%$ do PNB em 1977. Torna a crescer até 1982, quando atinge o valor de 0,0608. A partir de $1983(0,0354)$, o déficit entra em queda, atingindo o valor mais baixo em $1988(-0,0125)$.

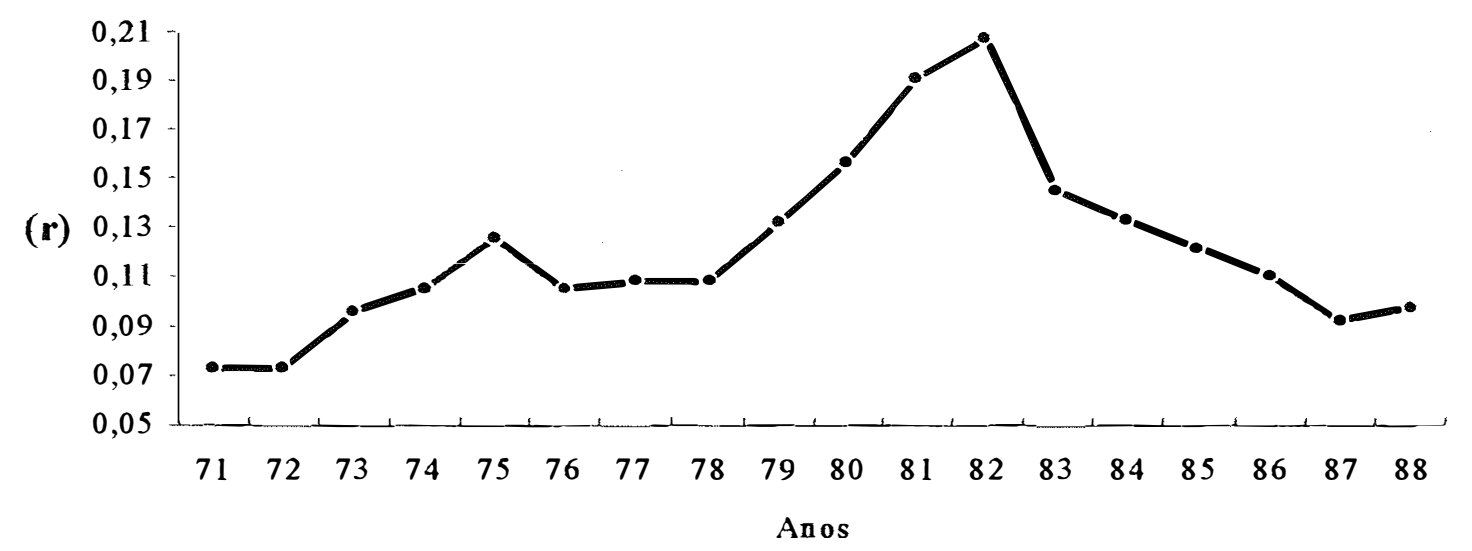

Figura 2. Taxas de juros (r).

A Figura 2 exibe o comportamento das taxas de juros (r) (quociente entre os juros líquidos pagos e o estoque da dívida líquida no ano anterior), apresentando forte incremento entre 1979 e 1982, quando passam de 0,1324 para 0,2075, ao ano. Caem a partir de 1983, atingindo 0,0926 (1987) e 0,0983 (1988). A queda é explicada pela diminuição das taxas de juros no mercado internacional e pela redução do montante de juros efetivamente pagos pelo Brasil. 


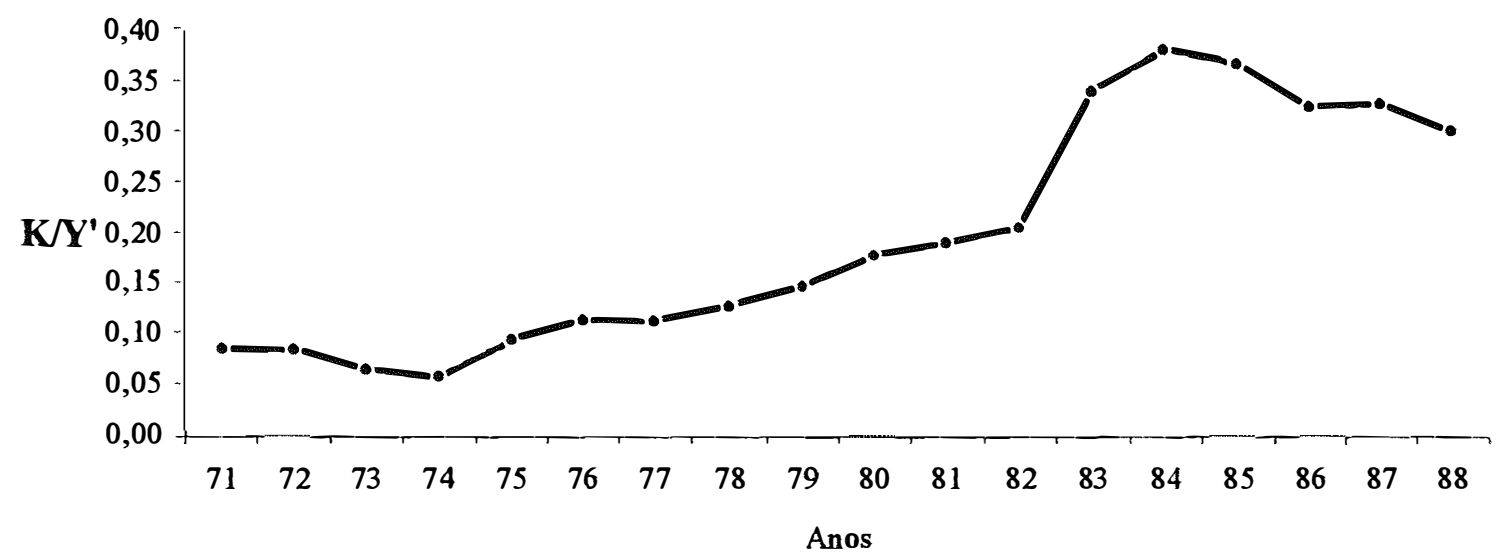

Figura 3. Dívida externa em relação ao Produto Nacional Bruto $\left(K / Y^{\prime}\right)$.

As outras variáveis externas (OVE/Y') (Figura 4) referem-se aos demais itens do balanço de serviços, excluídos os juros. Esses itens são os seguintes: 'viagens internacionais'; 'transportes'; 'seguros'; 'lucros e dividendos' e 'lucros reinvestidos' (com 'juros', formam a rubrica 'rendas de capitais'); 'despesas governamentais nãoincluídas em outros itens' e 'diversos'. Os dados apresentam picos nos anos de 1974 (0,0164), $1979(0,0173), 1982(0,0214), 1986(0,0168)$. Foram anos em que houve choques internacionais, com aumento do grau de incerteza na economia mundial. $\mathrm{O}$ valor cai bastante a partir de 1983, graças às restrições legais implementadas pelo governo brasileiro à saída de capitais.

A dívida externa (K/Y') (Figura 3) apreciou-se em relação ao PNB, de $1974(0,0566)$ a $1984(0,3805)$, decrescendo até 1988 (0,3001). A reversão dos fluxos de capitais, a partir de 1983, fez com que cessasse o aumento da dívida. Contudo, a capitalização dos serviços não pagos e a redução das taxas de crescimento do PNB, combinadas, redundaram em uma relação (K/' $\left.\mathbf{Y}^{\prime}\right)$ acima de 0,30, de 1984 em diante. 




Figura 4. Outras Variáveis Externas (OVE) em relação ao PNB ( $\left.Y^{\prime}\right)$.

As Figuras 5 e 6 apresentam o desempenho dos termos de troca das importações de produtos de origem agrícola e de origem não-agrícola $\left(\mathbf{P}_{\mathbf{m}} \mathbf{a} / \mathbf{P}_{\mathbf{y}}\right.$ e $\mathbf{P}_{\mathbf{m}} \mathbf{n} / \mathbf{P}_{\mathbf{y}}$, respectivamente). Os "termos de troca" são a relação entre os preços das importações e o deflator implícito do PIB. Os aumentos verificados nos biênios 1974-75 e 1979-80 devem-se aos choques de preços internacionais. O alto valor para 1979-80 é função ainda do choque cambial ocorrido, que também influencia o valor de 1983. A partir de 1984, verifica-se queda dos preços relativos desse gnupo de produtos.



Figura 5. Termos de troca das importações agrícolas $\left(\mathbf{P}_{\mathbf{m}} \mathbf{a} / \mathbf{P}_{\mathbf{y}}\right)$. 


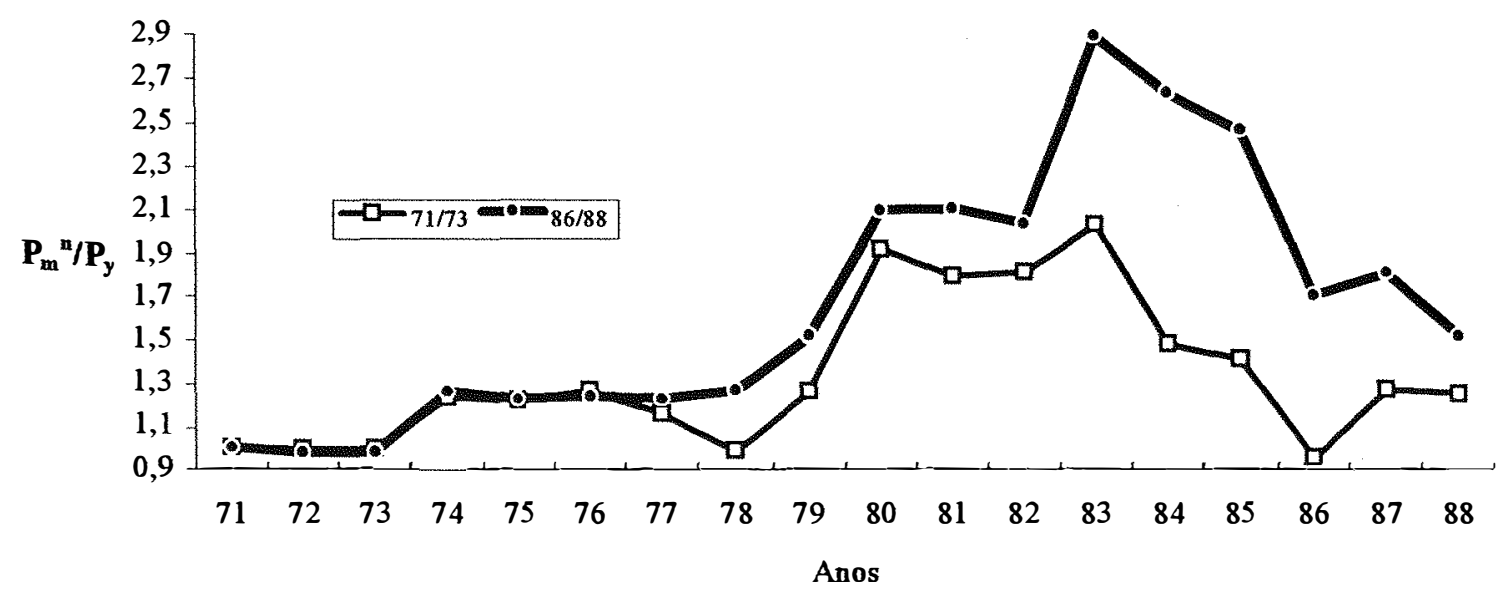

Figura 6. Termos de troca das importações não-agricolas $\left(\mathbf{P}_{\mathbf{m}}{ }^{\mathbf{n}} / \mathbf{P}_{\mathbf{y}}\right)$.

Até o ano de 1977, as duas séries têm aproximadamente os mesmos valores, tomando-se por base tanto os preços de 1971-73, como os de 1986-88. A partir daí, há uma descolagem entre elas, com elevação dos valores com base 1986-88. Isso é uma evidência de que a pauta de importações evoluiu no sentido de aumentar a participação de produtos com relativos de preços que caíram entre os períodos 1971-73 e 1986-88 33. Em outros termos: a composição das importações agrícolas ter-se-ía dirigido para produtos de preços mais reduzidos.

O desempenho dos termos de troca das exportações (relação entre os preços das exportações e o deflator implícito do PIB), tanto para produtos agrícolas $\left(\mathbf{P}_{\mathbf{x}} \mathbf{a} / \mathbf{P}_{\mathbf{y}}\right)$, como não-agrícolas $\left(\mathbf{P}_{\mathbf{x}} \mathbf{n} / \mathbf{P}_{\mathbf{y}}\right)$, está representado nas Figuras 7 e 8 . Ocorre apreciação relativa das exportações agrícolas ao longo da década de 70 , com queda nos anos 80. O pico de 1974 refere-se ao aumento dos preços internacionais das commodities. O pico de 1977 está relacionado com as quebras de safra (especialmente café), devido a fatores climáticos. As elevações registradas nos períodos 1979-80 e 198384 são explicadas pela desvalorização da taxa de câmbio.

33 Vide Apêndice 2. 




Figura 7. Termos de troca das exportações agrícolas $\left(\mathbf{P}_{\mathbf{x}}^{\mathbf{a}} / \mathbf{P}_{\mathbf{y}}\right)$.

Tomada a base 1986-88, em comparação à base 1971-73, percebe-se que a pauta das exportações agrícolas brasileiras caracteriza-se pela maior participação de produtos de relativos de preços mais reduzidos. Ou seja, as exportações agrícolas têm seus preços deprimidos entre os dois extremos do período sob estudo. A explicação para isto é que no começo dos anos 70 ocorreu forte elevação de preços das tradables agrícolas.

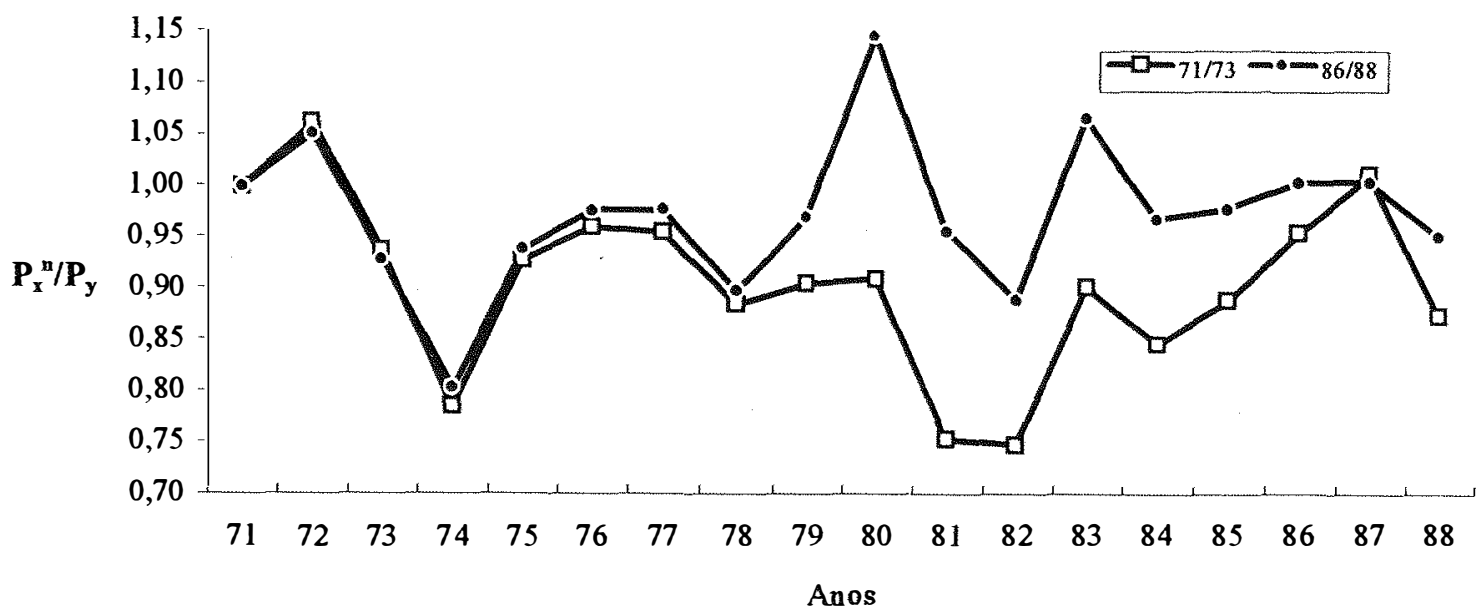

Figura 8. Termos de troca das exportações não-agrícolas $\left(\mathbf{P}_{\mathbf{x}}{ }^{\mathbf{n}} / \mathbf{P}_{\mathbf{y}}\right)$. 
Para as exportações não-agrícolas (Figura 8), a partir de 1979 verifica-se maior participação de produtos de menor relativo de preços (a preços de 1986-88). A disparidade entre os valores para as duas bases adotadas, observada de 1980 a 1984, refere-se a um menor relativo de preços de alguns produtos, em comparação a 1986-88, específico para esse período (pode-se considerar que o esforço exportador inicial se fez na direção de produtos de menor valor unitário).

Analisando-se os termos de troca, cumpre uma rápida observação sobre o comportamento da taxa de câmbio ao longo do período. A taxa de câmbio real efetiva, qualquer que seja o método de cálculo adotado, mostra-se desvalorizada em relação ao início dos anos 70. É favorável às tradables brasileiras, com um pico em 1980 (devido à maxidesvalorização de dezembro de 1979, que não persiste) e novo pico em 1983 (nova maxidesvalorização), que se prolonga em um patamar de elevada taxa de câmbio até 1988.

A política cambial contribuiu mais efetivamente para a restrição às importações não-agrícolas do que para os outros subsetores analisados. As maxidesvalorizações não se sustentaram para a agricultura, com desempenho pior, ao longo do tempo, comparativamente ao setor não-agrícola. A eficácia da maxidesvalorização diminuiu porque os preços externos das commodities caíram, corroendo seu efeito. Os termos de troca foram mais elevados para importą̧ões nãoagrícolas do que para as agrícolas (induzindo maior substituição de importações nãoagrícolas do que agrícolas). No contexto das políticas econômicas adotadas, de incentivo às exportações dos anos 80 , é somente junto ao setor não-agrícola que se verificou a manutenção do efeito da maxidesvalorização de 1983.

As Figuras 9 e 10 mostram a evolucão do comércio mundial, agrícola (Wa/U') e não-agrícola ( $\mathbf{W}^{\mathbf{n}} / \mathbf{U}^{\prime}$ ), em relação ao PNB. Para o setor agrícola (Figura 9), a relação cai até 1974, mantendo-se estável até o final da década, devido à reduzida evolução do comércio agrícola mundial, enquanto a economia brasileira crescia. A recessão interna do início dos anos 80 reverte esse quadro. As transações mundiais 
evoluíram proporcionalmente mais que a taxa de crescimento do produto e, após 1984, o PNB do Brasil tomou a crescer mais do que o comércio agrícola mundial. A relação Wa/U' está em patamar mais elevado para a série 1971-73 pois os preços das commodities eram maiores nesse período d o que no período 1986-88.

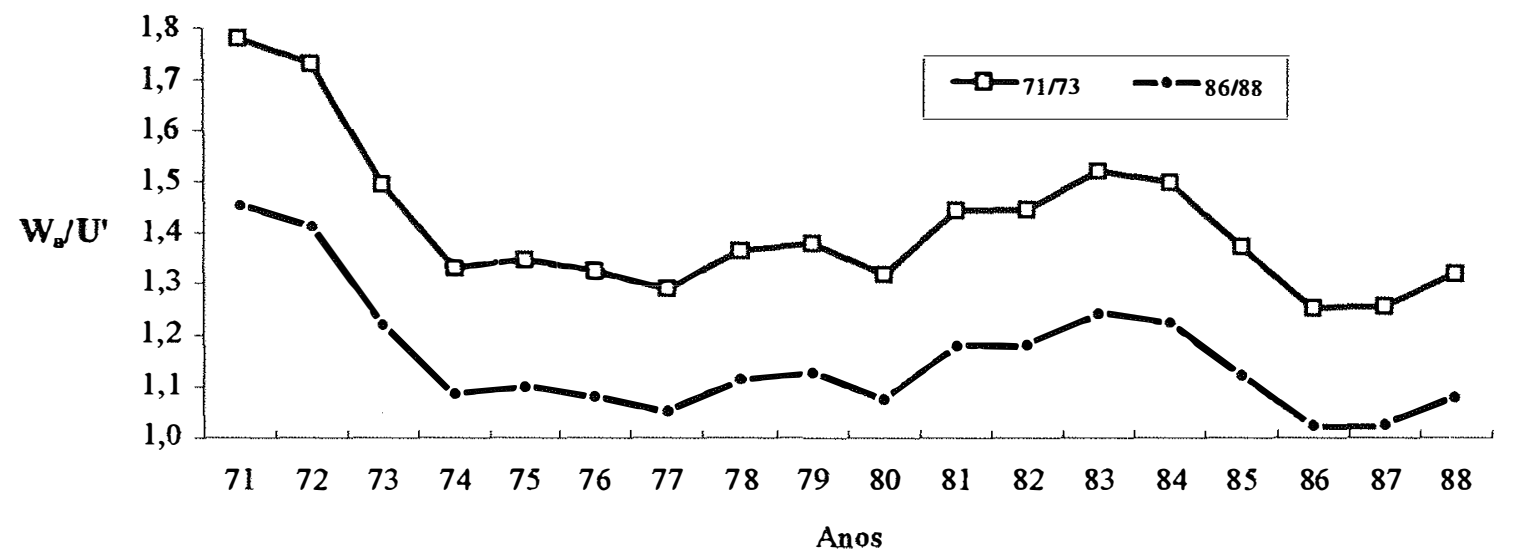

Figura 9. Comércio agrícola mundial em relação ao $\mathrm{PNB}\left(\mathbf{W}_{\mathbf{2}} / \mathbf{U}^{\prime}\right)$.

Após o primeiro choque do petróleo, o comércio não-agrícola mundial (Figura 10) cresceu em ritmo menor do que o produto brasileiro. Durante os anos 80, o quadro foi de ampliação do comércio mundial, contribuindo para o bom desempenho das exportações brasileiras. Note-se que os preços com base 1986-88 para as exportações não-agrícolas são mais elevados que os preços com base 1971-73. Perceba-se ainda que a distância entre as duas curvas tende a diminuir continuamente com o correr dos anos. Isso denota que, a preços de 1986-88, comparativamente aos preços de 1971-73, o comércio mundial direcionou-se a produtos de maior valor unitário. 


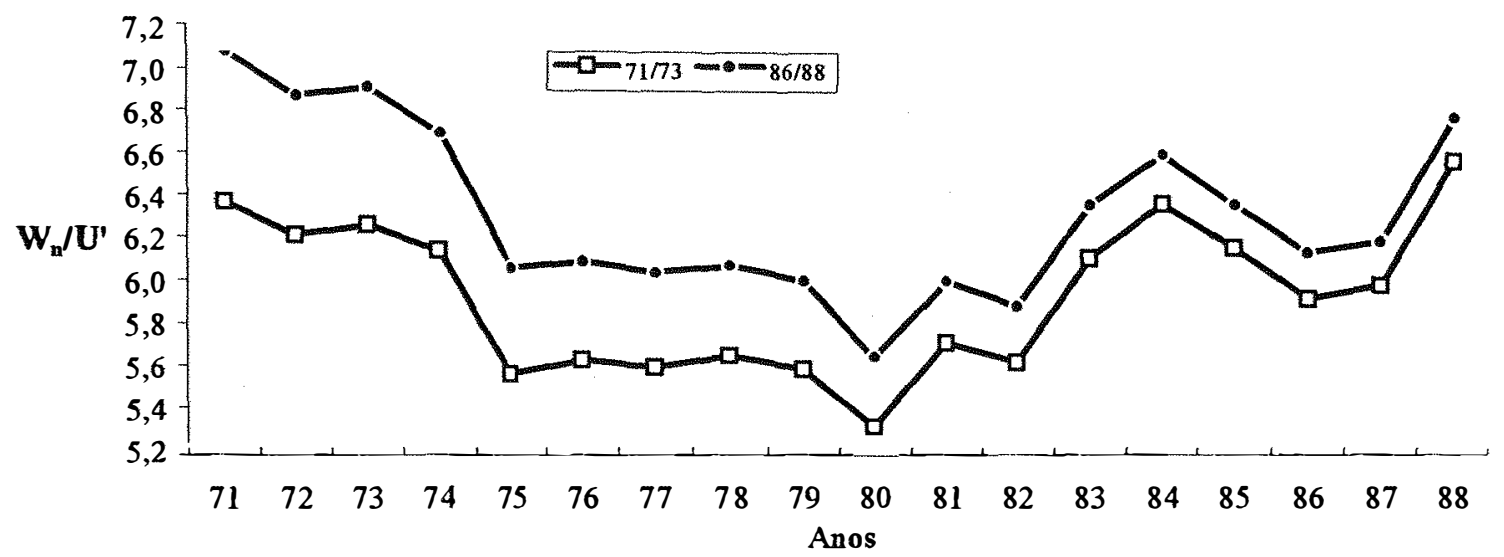

Figura 10. Comércio não-agrícola mundial $\left(\mathbf{W}_{\mathbf{v}} / \mathbf{U}^{\prime}\right)$.

$\mathrm{O}$ gasto doméstico em produtos de origem agrícola $\left(\mathbf{A}_{\mathbf{a}} / \mathbf{U}^{\prime}\right)$ consta da Figura 11, referindo-se ao valor da disponibilidade doméstica de produtos agrícolas: produção agrícola nacional, descontadas as exportações e acrescida das importações de produtos agrícolas. A variável $\left(\mathbf{A}_{\mathbf{a}} / \mathbf{U}^{\prime}\right)$ mostra comportamento razoavelmente constante a partir de 1973. Dentro do processo de desenvolvimento de um país, a absorção em produtos agrícolas tende a cair em proporção ao produto nacional, se a renda per capita estiver em evolução. Assim, o dado referente à relação entre absorção em produtos agrícolas e produto nacional, a preços constantes, seria uma evidência de que o padrão de consumo (e, por extensão, de vida) médio da sociedade brasileira ficou estagnado por quase duas décadas (até 1988).

A série de dados com base de preços 1971-73 encontra-se em patamar mais elevado que a série de base 1986-88. Os preços agrícolas médios mais elevados explicam essa diferença. A queda de ambas as séries no início dos anos 70 está relacionada com a maior taxação sobre os produtos agrícolas, acarretando em transferência de renda para o setor urbano-industrial. Além disso, a reforma tributária realizada nesse período aumentou a renda do governo, que não exerce grande demanda de produtos agropecuários. 


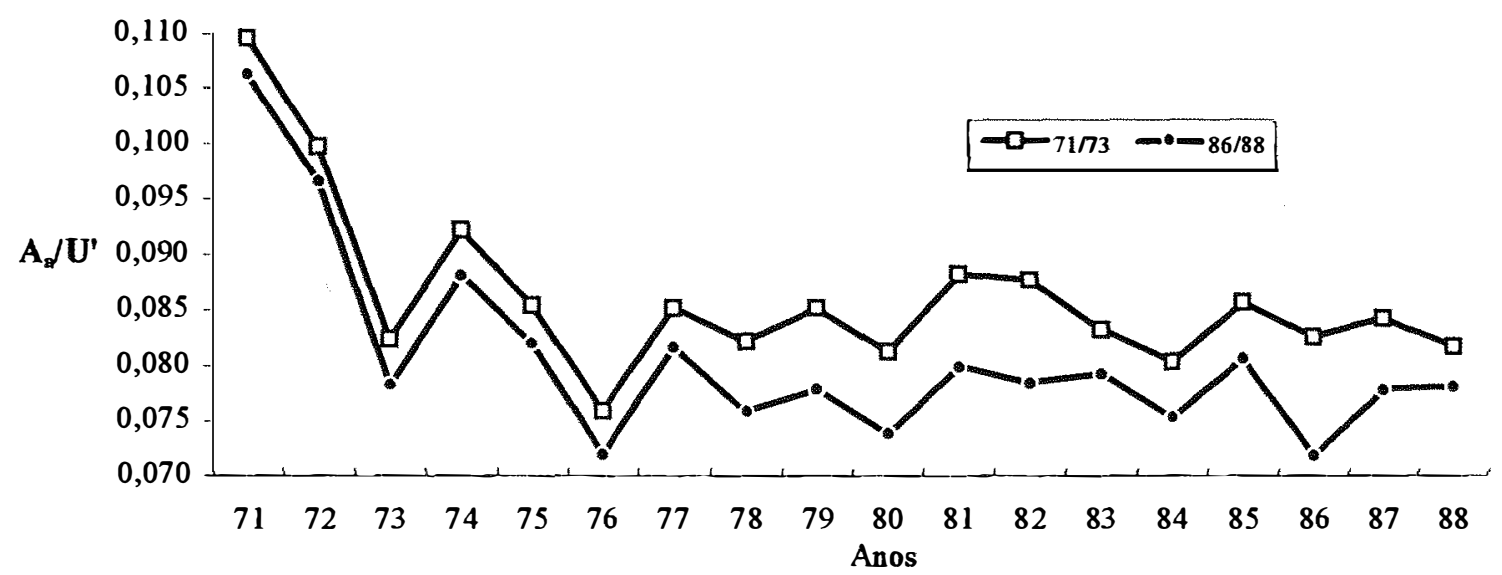

Figura 11. Gasto doméstico, setor agrícola $\left(\mathbf{A}_{\mathbf{2}} / \mathbf{U}^{\prime}\right)$.

Observando-se as curvas com bases em 1971-73 e 1986-88, nota-se que a distância vertical entre elas aumenta ao longo do tempo, a despeito do comportamento de ambas ser similar. Os dados mostram que o valor do numerador ( $\left.\mathbf{A}_{\mathbf{a}}\right)$ do quociente, a preços 1986-88, cai ao longo do tempo, indicando que cresceu o consumo doméstico dos produtos agrícolas cujos preços caíram mais, entre 1973 e 1988.

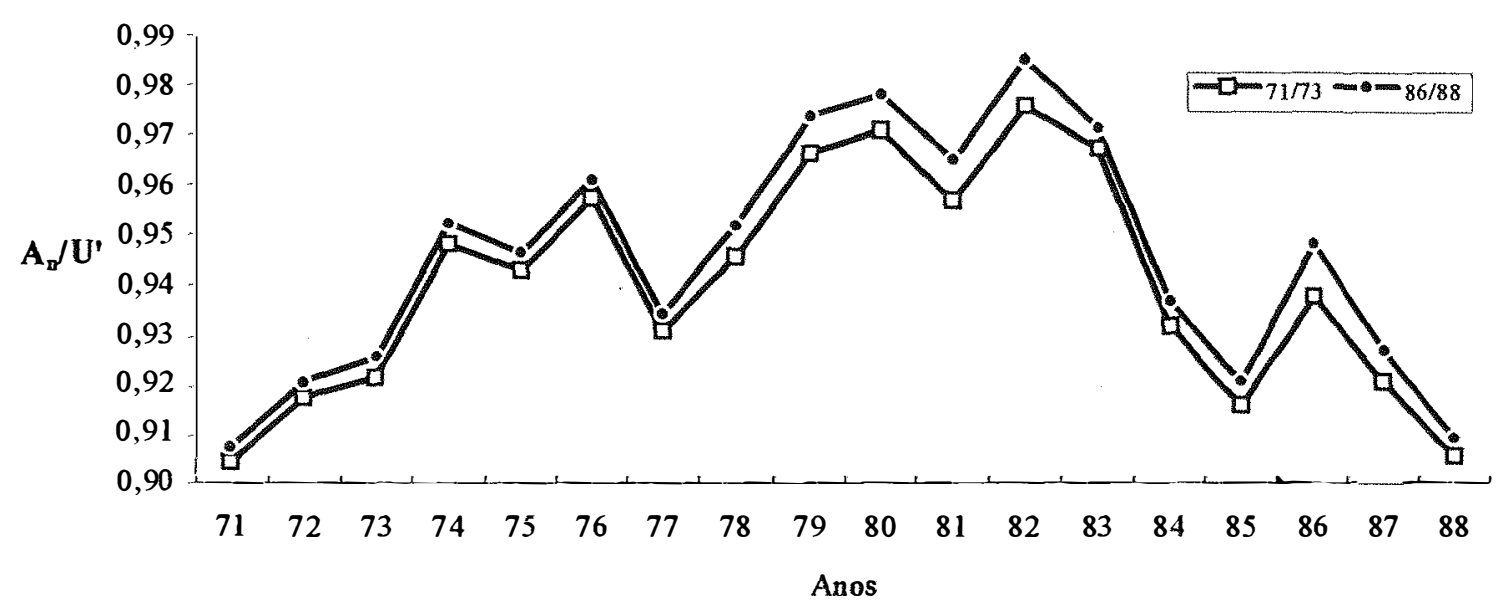

Figura 12. Gasto doméstico, setor não-agńcola $\left(\mathbf{A}_{\mathbf{v}} / \mathbf{U}^{\prime}\right)$. 
$O$ gasto doméstico em produtos não-agrícolas $\left(A_{n} / U^{\prime}\right)$ encontra-se ilustrado na Figura 12. A absorção elevou-se em relação ao PNB, ao longo da década de 70, graças aos financiamentos externos, que possibilitaram o gasto doméstico ser maior do que o produto nacional. Essa relação sofreu forte queda devido ao processo recessivo do início dos anos 80 , forçando cortes em despesas, principalmente em investimento.

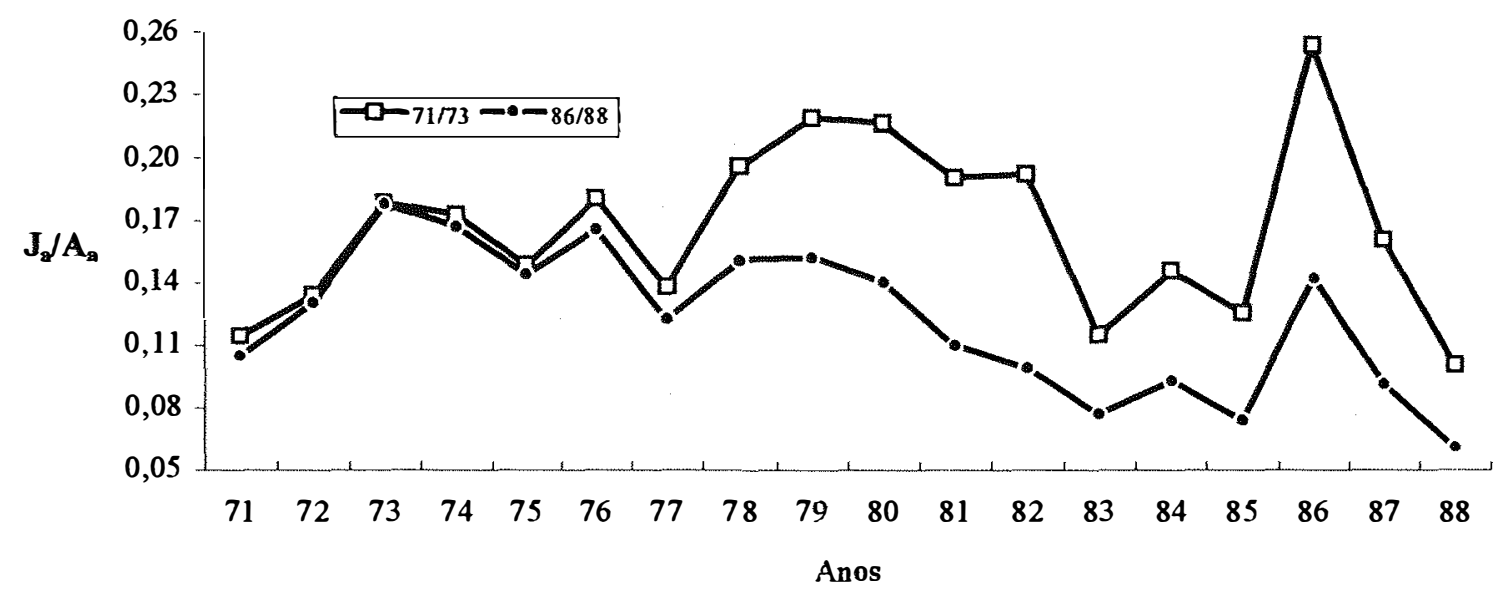

Figura 13. Substituição de importações do setor agrícola $\left(\mathbf{J}_{\mathbf{2}} / \mathbf{A}_{\mathbf{s}}\right)$.

$\mathrm{Na}$ substituição de importações (Figura 13, para o setor agrícola $\left(\mathbf{J}_{\mathbf{a}} / \mathbf{A}_{\mathbf{a}}\right)$ e Figura 14, para o setor não-agrícola $\left.\left(\boldsymbol{J}_{\mathbf{n}} / \mathbf{A}_{\mathbf{n}}\right)\right)$, a variável em questão é a relação entre importações e absorção para os respectivos setores, em valores constantes. Nota-se redução das quantidades importadas, a partir do fim dos anos 70 (excetuando-se 1986, ano do Plano Cruzado). Este movimento redutor do quantum dá-se em direção a produtos de menores preços, considerada a base 1986-88.

Quanto ao setor agrícola (Figura 13), os valores são aproximados, até 1977, para ambas as bases de preços. A partir de 1978, passam a cair as importações de insumos para agricultura, cujos preços são, na média, maiores que os preços dos produtos finais. Assim, os resultados obtidos com base 1971-73 apresentam valores mais elevados que os de base 1986-88, pois neste último grupo produtos com relativos de preços menores têm maior participação no índice. 


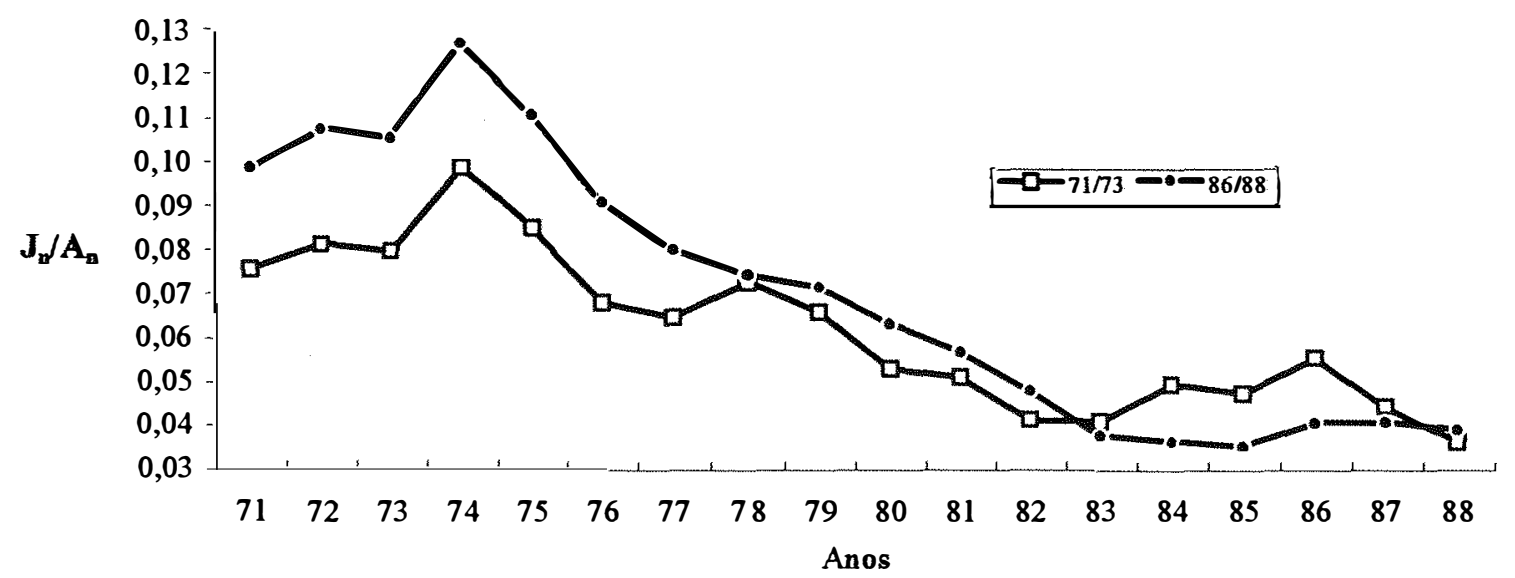

Figura 14. Substruição de importações do setor não-agrícola $\left(\mathbf{J}_{\mathbf{n}} / \mathbf{A}_{\mathbf{n}}\right)$.

A substituição de importações do setor não-agrícola também foi bem sucedida, caindo cerca de $50 \%$ no período (vide Figura 14 ). O processo de queda iniciase em 1975, e permanece até quase o final d o período.

A penetracão das exportações está representada na Figura 15, para o setor agrícola $\left(\mathbf{Z}_{\mathbf{a}} / \mathbf{W}_{\mathbf{a}}\right)$, e na Figura 16 , para o setor não-agrícola $\left(\mathbf{Z}_{\mathbf{n}} / \mathbf{W}_{\mathbf{n}}\right)$. $O$ indicador utilizado é a relação entre as quantidades exportadas pelo setor e o total do respectivo mercado externo. Para os dois setores analisados, a série a preços 1971-73 apresenta-se em patamar superior ao da série 1986-88. Conclui-se que, a preços com base 1986-88, as exportações brasileiras tiveram seu valor depreciado em relação aos bens transacionados nos mercados mundiais.

Tomando-se os dados de penetração das exportações agrícolas (Figura 15), no início e no final do período, nota-se a manutenção da participação brasileira nos mercados agrícolas mundiais. A análise da série evidencia o esforço de conquista de mercados ao longo dos anos 80 , em comparação ao desempenho da década de 70. A preços de 1986-88, os valores são inferiores aos verificados com base em 197173. O aumento das distâncias entre os dados, ano a ano, denota que a pauta de tradables brasileiras teve seu preço médio reduzido em comparação à dinâmica de crescimento do comércio mundial de produtos de origem agrícola. Ao longo do tempo, a pauta de 
exportações nacionais encaminhou-se para produtos relativamente mais baratos, em relação aos produtos transacionados internacionalmente.

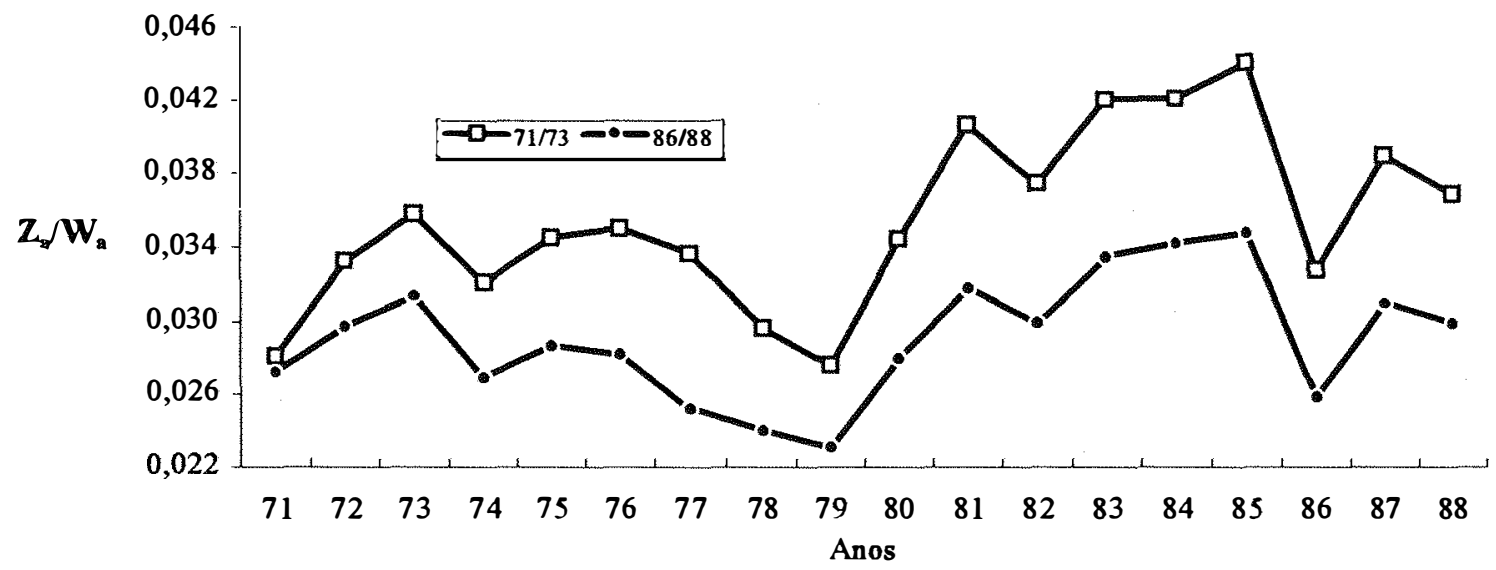

Figura 15. Penetração das exportações do setor agricola $\left(\mathbf{Z}_{\mathbf{s}} \mathbf{W}_{\mathbf{s}}\right)$.

O setor não-agrícola (Figura 16) mostrou excelente desempenho quanto à conquista de mercados (o quociente cresce cerca de $250 \%$, entre 1971 e 1988). O esforço exportador ocorreu em direção de produtos cujos preços sofreram queda ao longo do período, comparativamente aos preços médios do mercado mundial. Embora o quociente cresça, as distâncias ano a ano aumentam, tomando-se as duas bases de preço.

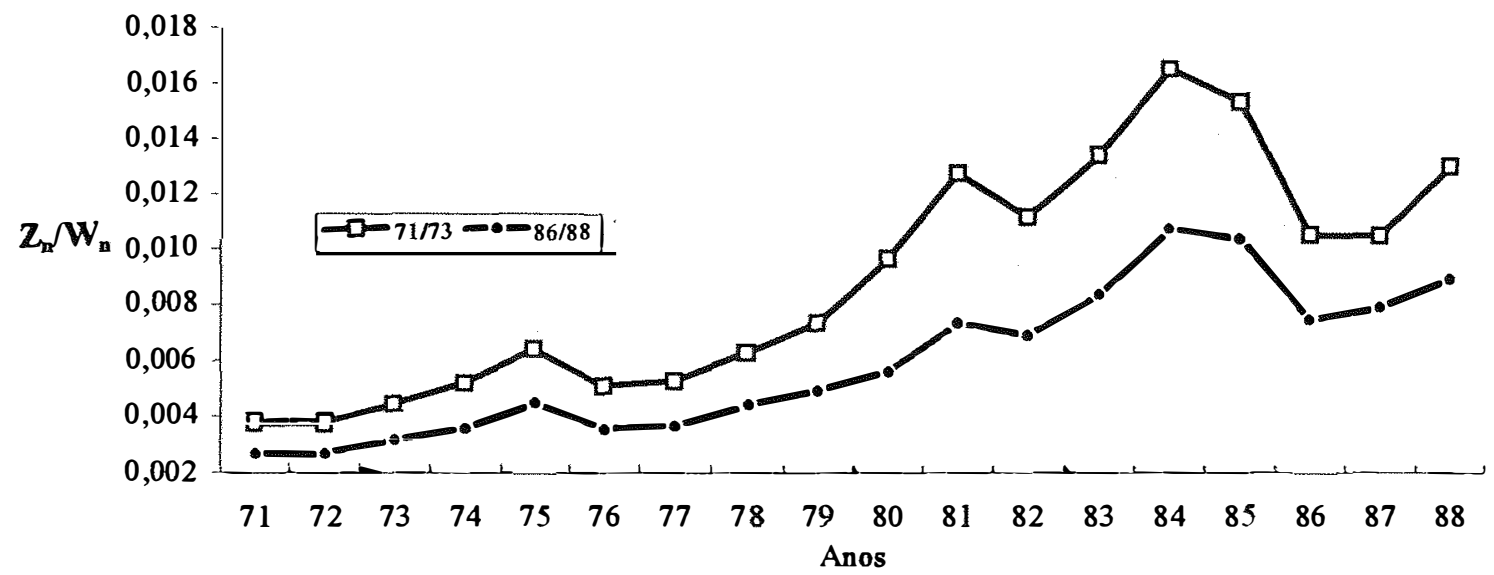

Figura 16. Penetração das exportações do setor não-agrícola $\left(\mathbf{Z}_{\mathbf{2}} \mathbf{W}_{\mathbf{n}}\right)$. 


\subsection{Do modelo de decomposição}

Conforme demonstrado na seção 3.1, a decomposição do saldo em transações correntes é dividida em três grupos principais: (1) efeitos dos choques externos; (2) ônus da dívida externa e de outras variáveis externas e (3) condução das políticas internas. A somatória dos valores encontrados para esses três grupos fornece o

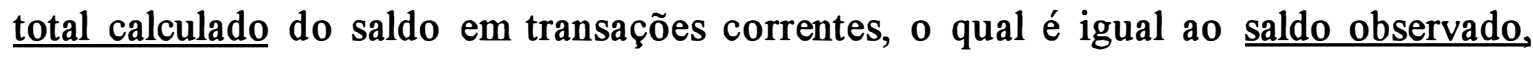
descontados os resíduos referentes aos efeitos de interação e erros de arredondamento.

Os resultados adotados foram os que apresentaram os resíduos mínimos. Em virtude dos resíduos, a interpretação dos resultados não pode considerar os valores obtidos como sendo as contribuições exatas de cada uma das variáveis às alterações do saldo em contas correntes. Todavia, pode-se assumir que o valor real esteja próximo dos resultados calculados e, para fins analíticos, é o comportamento dos sinais o que importa.

O período sob enfoque -- décadas de 70 e 80 -- recebeu três cortes temporais: 1973, 1978 e 1983, denominados "anos-base". São anos imediatamente anteriores à ocorrência de choques exógenos que, a priori, constituir-se-íam nas causas dos problemas enfrentados com o balanço em transações correntes durante os anos subseqüentes. São também anos de definição de estratégias globais de ajuste da economia brasileira.

Em fins de 1973 e em 1979 aconteceram dois choques de preços do petróleo. Em 1983, consolidou-se a nova estratégia do sistema financeiro internacional para a dívida externa dos países em desenvolvimento. Cessaram os fluxos monetários que permitiram o equilíbrio das contas do balanço de pagamentos. Isso levou as economias endividadas a intensificarem seus processos de ajuste interno. A partir de 1984, o Brasil adotou um modelo voltado para o incremento das exportações, tentando afastar-se das condições recessivas do triênio 1981/83. Em 1979 e em 1983 ocorreram maxidesvalorizações da taxa de câmbio. 
BACHA (1984) adota idêntica divisão de períodos. Os resultados (vide Tabelas 10.1 e 10.2, Apêndice 1) são semelhantes aos obtidos na presente pesquisa. Via de regra, os sinais são os mesmos, e a magnitude das variáveis evolui de modo aproximado. Os resíduos obtidos por Bacha são menores, em média, provavelmente porque ele não procedeu a uma divisão da economia em dois setores, tendo trabalhado com um número mais reduzido de fontes de geração de resíduos, em comparação à presente pesquisa.

O esforço de minimizar os resíduos das estimativas é um paciente trabalho de testar combinações de fatores de ponderação, bases de coletas de preços e valor utilizado para produto nacional (produto potencial ou efetivo; produto nacional bruto ou produto interno bruto). Após algumas tentativas, verificou-se que, variando-se os critérios em uso, o sinal e a magnitude de cada fator de decomposição não se alterava a ponto de afetar a interpretação dos resultados. Assim, optou-se por adotar a base de preços médios para 1971-73, e o Produto Nacional Bruto (PNB) efetivo, para se proceder às estimativas da decomposição (16) da equação (15).

\subsubsection{O subperíodo 1974-1978.}

A Tabela 5 mostra o aumento do déficit em contas correntes após o choque do petróleo de 1973. A alínea "saldo em transações correntes" evidencia isso: média do saldo calculado de 2,85, e do saldo observado de 2,30. A análise da decomposição contábil do subperíodo $1974-78$ permite individualizar as participações de cada variável no incremento do déficit, conforme se segue.

As autoridades econômicas nacionais mostraram certa reação, nesse período, no sentido de iniciar o ajuste interno. A alínea "políticas domésticas" teve valor médio de $-0,24 \%$, apesar dos $2,35 \%$ em 1974. Nos demais anos, 1975 a 1978, o valor foi negativo (ajudou o ajuste). Optou-se por não interromper o processo de crescimento, 
tanto é que ocorreu expansão dos gastos domésticos $\left(\mathbf{A}_{\mathbf{a}} / \mathbf{U}^{\prime}\right.$ médio de $0,04 \%$ e $\mathbf{A}_{\mathbf{n}} / \mathbf{U}^{\prime}$ médio de $0,19 \%$ ). Por outro lado, as importações, como proporção da absorção, foram

Tabela 5. Brasil. Decomposição ${ }^{1}$ das variações dos saldos em conta corrente, entre cada ano no período 1974/78 e o ano-base de 1973 (todas as variáveis são proporções do PNB). Base de preços 1971-73.

\begin{tabular}{|c|c|c|c|c|c|c|c|}
\hline Fatores explicativos & & 1974 & 1975 & 1976 & 1977 & 1978 & Média \\
\hline \multicolumn{8}{|l|}{ Choques externos } \\
\hline \multirow[t]{4}{*}{ Variação das relações de troca } & $\mathbf{P}_{\mathbf{m}} \mathbf{a} / \mathbf{P}_{\mathbf{y}}$ & 0,45 & 0,28 & $-0,06$ & $-0,15$ & $-0,31$ & 0,04 \\
\hline & $\mathbf{P}_{\mathbf{m}} \mathbf{n}_{\mathbf{P}} \mathbf{y}$ & 1,76 & 1,62 & 1,96 & 1,17 & $-0,05$ & 1,29 \\
\hline & $\mathbf{P}_{\mathbf{x}} \mathbf{a} / \mathbf{P}_{\mathbf{y}}$ & $-0,49$ & 1,13 & 0,73 & $-0,13$ & 0,77 & 0,40 \\
\hline & $\mathbf{P}_{\mathbf{x}} \mathbf{n}_{\mathbf{P}} \mathbf{\mathbf { P } _ { \mathbf { y } }}$ & 0,43 & 0,03 & $-0,06$ & $-0,05$ & 0,15 & 0,10 \\
\hline Taxa de juros & $\mathbf{r}$ & 0,06 & 0,19 & 0,06 & 0,08 & 0,08 & 0,09 \\
\hline \multirow[t]{2}{*}{ Variação do comércio mundial } & $\mathbf{w}^{\mathbf{a} / \mathbf{U}^{\prime}}$ & 0,73 & 0,66 & 0,76 & 0,91 & 0,58 & 0,73 \\
\hline & $\mathbf{W}^{\mathbf{n}} / \mathbf{U}^{\prime}$ & 0,05 & 0,29 & 0,26 & 0,27 & 0,25 & 0,22 \\
\hline \multirow[t]{3}{*}{ Outras variáveis externas } & $\mathbf{K} / \mathbf{Y}^{\prime}$ & $-0,08$ & 0,28 & 0,47 & 0,46 & 0,60 & 0,35 \\
\hline & $\mathbf{V}_{\mathbf{d}} / \mathbf{Y}^{\prime}$ & 0,18 & $-0,09$ & $-0,06$ & $-0,29$ & $-0,29$ & $-0,11$ \\
\hline & $\mathbf{T} / \mathbf{Y}^{\prime}$ & $-0,03$ & $-0,03$ & $-0,03$ & $-0,03$ & 0,00 & $-0,02$ \\
\hline \multicolumn{8}{|l|}{ Políticas Domésticas } \\
\hline \multirow[t]{2}{*}{ Gasto doméstico } & $\mathbf{A}_{\mathbf{a}} / \mathbf{U}^{\prime}$ & 0,20 & 0,06 & $-0,13$ & 0,06 & 0,00 & 0,04 \\
\hline & $\mathbf{A}_{n} / \mathbf{U}^{\prime}$ & 0,21 & 0,17 & 0,29 & 0,08 & 0,20 & 0,19 \\
\hline \multirow[t]{4}{*}{ Competitividade externa } & $\mathbf{J}_{\mathbf{a}} / \mathbf{A}_{\mathbf{a}}$ & $-0,05$ & $-0,27$ & 0,02 & $-0,36$ & 0,16 & $-0,10$ \\
\hline & $\mathbf{J}_{n} / \mathbf{A}_{n}$ & 1,75 & 0,49 & $-1,08$ & $-1,38$ & $-0,63$ & $-0,17$ \\
\hline & $\mathbf{z}_{\mathbf{a}} / \mathbf{w}_{\mathbf{a}}$ & 0,69 & 0,24 & 0,15 & 0,40 & 1,14 & 0,52 \\
\hline & $z_{n} / W_{n}$ & $-0,44$ & $-1,15$ & $-0,39$ & $-0,50$ & $-1,10$ & $-0,72$ \\
\hline Choques externos & & 2,98 & 4,20 & 3,65 & 2,10 & 1,47 & 2,88 \\
\hline Outras variáveis externas & & 0,07 & 0,16 & 0,38 & 0,14 & 0,31 & 0,21 \\
\hline Políticas domésticas & & 2,35 & $-0,47$ & $-1,14$ & $-1,71$ & $-0,23$ & $-0,24$ \\
\hline \multirow{3}{*}{$\begin{array}{c}\text { Saldo em transações } \\
\text { correntes }\end{array}$} & Calculado & 5,40 & 3,88 & 2,89 & 0,53 & 1,54 & 2,85 \\
\hline & Observado & 4,51 & 3,22 & 1,95 & 0,29 & 1,54 & 2,30 \\
\hline & Resíduo & 0,89 & 0,66 & 0,94 & 0,24 & 0,01 & 0,56 \\
\hline Setor agrícola & & 1,52 & 2,10 & 1,47 & 0,73 & 2,34 & 1,63 \\
\hline
\end{tabular}

Fonte: cálculos do autor.

1 Os fatores de decomposição foram calculados utilizando-se como pesos os valores observados para o ano base. 
controladas ( $\mathbf{J}_{\mathbf{a}} / \mathbf{A}_{\mathbf{a}}$ médio de -0,10\% e $\mathbf{J}_{\mathbf{n}} / \mathbf{A}_{\mathbf{n}}$ médio de -0,17\%). Quanto às importações para o setor agrícola, o desempenho melhorou graças à queda nas importações de máquinas e equipamentos, de insumos para fabricação de papel, de fertilizantes, enfim, de insumos que, dentro da política de substituição de importações, começaram a ser produzidos internamente, e tomaram o lugar dos similares importados.

O grupo "choques externos", com média de $2,88 \%$, foi o que mais contribuiu para a elevação no déficit em transações correntes nesse período. Individualmente, o item de pior desempenho foi o de termos (ou relações) de troca das importações não-agrícolas $\left(\mathbf{P}_{\mathbf{m}} \mathbf{n} / \mathbf{P}_{\mathbf{y}}\right)$, com 1,29\%, médios. Os termos de troca das importações agrícolas $\left(\mathbf{P}_{\mathbf{m}} \mathbf{a} / \mathbf{P}_{\mathbf{y}}\right)$ tiveram impacto quase nulo $(0,04 \%$, em média), com ajuste notado de 1976 em diante (sinal negativo). Ou seja, houve um ajuste das importações agrícolas, no sentido de se diminuir a participação dos bens cujos preços internacionais estavam aumentando.

Os termos de troca das exportações agrícolas $\left(\mathbf{P}_{\mathbf{x}} \mathbf{a} / \mathbf{P}_{\mathbf{y}}\right)$ tiveram desempenho médio desfavorável $(0,40 \%)$, tendo ajudado a corrigir o déficit somente em $1974(-0,49 \%)$ e $1977(-0,13 \%)$. Todavia, os preços externos dos produtos agrícolas subiram durante meados da década de 70. Assim, conchi-se que as exportações agrícolas brasileiras, embora crescendo o valor total delas, em um mercado de preços em alta, dirigiu-se justamente para os produtos cujo preço esteve em queda. $\mathrm{O}$ efeito positivo dos termos de troca de exportações agrícolas em 1977 é explicado pela explosão dos preços das commodities e, em particular, do café, devido às geadas nas regiões cafeicultoras brasileiras.

O volume do comércio mundial elevou-se em ritmo inferior ao crescimento do produto brasileiro (os quocientes têm sinal positivo), denotando redução nas oportunidades de colocação dos produtos nacionais nos mercados externos. Todavia, o mercado agrícola internacional contraiu-se mais do que o de produtos não-agrícolas, conforme apontam as respectivas taxas médias: $\mathbf{W}_{\mathbf{a}} / \mathbf{U}^{\prime}$ de 0,73 e $\mathbf{W}_{\mathbf{n}} / \mathbf{U}^{\prime}$ de 0,22 . 
Quanto à competitividade externa, as exportações agrícolas contribuíram para o aumento do déficit nos anos 70. $\mathrm{O}$ dinamismo dessas exportações foi reduzido, perdendo participação no respectivo comércio mundial $\left(\mathbf{Z}_{\mathbf{a}} / \mathbf{W}_{\mathbf{a}}\right.$ médio de 0,52\%), no período 1974/78. Já as exportações de não-agrícolas ganharam mercado $\left(\mathbf{Z}_{\mathbf{n}} / \mathbf{W}_{\mathbf{n}}\right.$ médio de -0,72\%), auxiliando a redução do déficit.

A alínea "outras variáveis externas" apresentou valor médio de $0,21 \%$, com uma diferença de comportamento entre o componente financeiro do déficit (“acúmulo da dívida externa líquida", $\mathbf{K} / \mathbf{Y}$ ') e as demais variáveis do grupo (outras rendas de capitais e trabalho, $\mathbf{V}_{\mathbf{d}} / \mathbf{Y}^{\prime}$ e tranferências unilaterais, $\mathbf{T} / \mathbf{Y}^{\prime}$ ). A elevação da dívida externa nos anos 70 é evidenciada por sua crescente contribuição ao aumento do déficit, com K/Y' médio de 0,35\%, saindo de $-0,08 \%$ em 1974, para 0,60\% em 1978 . $\mathbf{V}_{\mathbf{d}} / \mathbf{Y}^{\prime}$ e $\mathbf{T} / \mathbf{Y}^{\prime}$ exercem pequena influência na correção do déficit: médias de $-0,11 \%$ e $0,02 \%$, respectivamente. Também as taxas de juros (r) não apresentam grandes elevações ao longo do período (por volta de 8 a $9 \%$, ao ano), contribuindo com valor médio de qüinqüenal de $0,09 \%$ para o incremento do déficit.

A última linha da Tabela 5 aponta valor médio de 1,63\% do PNB para o setor agrícola (aumentando o déficit). Esse fato é contrabalançado pelas conquistas de mercado efetuadas pelo setor não-agrícola, demonstrando o potencial exportador da indústria nacional. Trata-se de um fator preponderante para que se caracterize a firmeza na adoção de políticas domésticas para redução do déficit, a partir de 1975. O ajuste ocorreu em especial do lado não-agrícola da economia; tanto graças ao esforço exportador, quanto à política de redução e substituição de importações, que passa a mostrar resultados positivos de 1976 em diante. O ajuste do gasto doméstico é tímido, apresentando, a partir de 1975, leve tendência (nunca superior a 0,29\% do PNB) no sentido da deterioração das contas externas.

Em 1978, conjuntamente à expansão da dívida, são as variáveis referentes ao setor exportador da agricultura as principais responsáveis pelo aumento do déficit: há deterioração das relações de troca $(0,77 \%)$; contração do comércio mundial 
(0,58\%); e redução da participação das exportações agricolas brasileiras $(1,14 \%)$, em relação ao ano-base $(1973){ }^{34}$. A pressão relativa do setor agrícola sobre o déficit calculado aumenta de modo substancial ao longo do tempo: $28,1 \%$ em 1974, 54,1\% em 1975, 50,9\% em 1976, 137,7\% em 1977 e 157,9\% em 1978 (valores acima de 100\% indicam que o setor agrícola produziu, sozinho, déficit maior do que o efetivamente observado).

\subsubsection{O subperíodo 1979-1983}

Os resultados para o subperíodo 1979-1983 (ano-base 1978) constam da Tabela 6. O saldo em transações correntes apresenta crescimento do déficit: média do saldo calculado de $1,72 \%$ e de $1,40 \%$ do observado. O valor é positivo até 1982 , mudando de sinal em 1983 (-0,74\% calculado; -0,04\% observado). O principal item responsável por essa mudança em 1983 foram as políticas domésticas (-10,73\%). Na média, para os cinco anos, os choques externos $(5,98 \%)$ e as outras variáveis externas $(1,12 \%)$ respondem pelo desequilíbrio das contas correntes. As políticas domésticas adotadas mostram resultados que fazem reduzir o déficit $(-6,08 \%)$.

A contribuição do setor agrícola ao ajuste é favorável. A última linha da Tabela 6 resume o comportamento do setor. A média para o período é $-0,61 \%$. Os valores ajudam na redução do déficit em três anos (1980, com -0,65\%; 1981, com $0,72 \%$ e 1983 , com $-2,13 \%$ ). Os valores positivos são reduzidos: $0,32 \%$, em 1979 e $0,11 \%$, em 1982 .

A contribuição do setor agrícola ocorre, principalmente, através da melhoria da penetração das exportações $\left(\mathbf{Z}_{\mathbf{a}} / \mathbf{W}_{\mathbf{a}}\right.$ de $-0,96 \%$, em média $)$, em particular de 1980 em diante; da ampliação do comércio mundial $\left(\mathbf{W}_{\mathbf{a}} / \mathbf{U}^{\prime}\right.$ de $-0,19 \%$, em média $)$ e da

\footnotetext{
${ }^{34}$ É importante ressaltar que as exportações agrícolas apresentavam-se em crescimento entre 1967 e 1972. O valor para o ano de 1973, que foi de pico das exportações agrícolas, talvez mascare o esforço subseqüente de ajuste do setor, quando se toma por base de comparação esse ano.
} 
substituição de importações agrícolas $\left(\mathbf{J}_{\mathbf{a}} / \mathbf{A}_{\mathbf{a}}\right.$ médio de -0,10\%). Em contrapartida, a subida dos preços das importações agrícolas $\left(\mathbf{P}_{\mathbf{m}} \mathbf{a} / \mathbf{P}_{\mathbf{y}}\right.$ médio de $\left.0,20 \%\right)$, a queda dos preços das commodities, acarretando redução nos termos de troca das exportações

Tabela 6. Brasil. Decomposição ${ }^{1}$ das variações dos saldos em conta corrente, entre cada ano no período 1979/83 e o ano-base de 1978 (todas as variáveis são proporções do PNB). Base de preços 1971-73.

\begin{tabular}{|c|c|c|c|c|c|c|c|}
\hline Fatores explicativos & & 1979 & 1980 & 1981 & 1982 & 1983 & Média \\
\hline \multicolumn{8}{|l|}{ Choques externos } \\
\hline \multirow[t]{4}{*}{ Variação das relações de troca } & $P_{m} \mathbf{a} / P_{y}$ & 0,18 & 0,48 & 0,02 & $-0,28$ & 0,59 & 0,20 \\
\hline & $\mathbf{P}_{\mathbf{m}} \mathbf{n} / \mathbf{P}_{\mathbf{y}}^{\mathbf{y}}$ & 1,79 & 5,55 & 4,69 & 4,47 & 5,63 & 4,43 \\
\hline & & $-0,36$ & $-0,70$ & 1,00 & 1,59 & 0,46 & 0,40 \\
\hline & & $-0,08$ & $-0,11$ & 0,72 & 0,68 & $-0,11$ & 0,22 \\
\hline Taxa de juros & $\mathbf{r}$ & 0,32 & 0,73 & 1,30 & 1,63 & 0,85 & 0,97 \\
\hline \multirow[t]{2}{*}{ Variação do comércio mundial } & $\mathbf{W}^{\mathbf{a} / \mathbf{U}^{\prime}}$ & $-0,05$ & 0,18 & $-0,27$ & $-0,25$ & $-0,58$ & $-0,19$ \\
\hline & $\mathbf{W}^{\mathbf{n}} / \mathbf{U}^{\prime}$ & 0,04 & 0,23 & $-0,05$ & 0,01 & $-0,41$ & $-0,04$ \\
\hline \multirow[t]{3}{*}{ Outras variáveis externas } & $\mathbf{K} / \mathbf{Y}^{\prime}$ & 0,23 & 0,20 & 0,63 & 1,05 & 1,49 & 0,72 \\
\hline & $\mathbf{V}_{\mathbf{d}} / \mathbf{Y}^{\prime}$ & 0,56 & 0,20 & 0,20 & 0,90 & 0,16 & 0,40 \\
\hline & $\mathbf{T} / \mathbf{Y}^{\prime}$ & $-0,03$ & 0,03 & 0,04 & $-0,05$ & 0,00 & 0,00 \\
\hline \multicolumn{8}{|l|}{ Políticas Domésticas } \\
\hline \multirow[t]{2}{*}{ Gasto doméstico } & $\mathbf{A}_{\mathbf{a}} / \mathbf{U}^{\prime}$ & 0,06 & $-0,02$ & 0,10 & 0,09 & 0,02 & 0,03 \\
\hline & $\mathbf{A}_{\mathbf{n}} / \mathbf{U}^{\prime}$ & 0,16 & 0,23 & 0,10 & 0,24 & 0,19 & 0,18 \\
\hline \multirow[t]{4}{*}{ Competitividade externa } & $\mathbf{J}_{\mathbf{a}} / \mathbf{A}_{\mathbf{a}}$ & 0,18 & 0,17 & $-0,05$ & $-0,03$ & $-0,75$ & $-0,10$ \\
\hline & $\mathbf{J}_{\mathbf{n}} / \mathbf{A}_{\mathbf{n}}$ & $-0,72$ & $-2,74$ & $-2,81$ & $-4,18$ & $-4,57$ & $-3,00$ \\
\hline & $\mathbf{z}_{\mathbf{a}} / \mathbf{W}_{\mathbf{a}}$ & 0,32 & $-0,75$ & $-1,52$ & $-1,01$ & $-1,86$ & $-0,96$ \\
\hline & $\mathbf{z}_{\mathbf{n}} / \mathbf{W}_{\mathbf{n}}$ & $-0,54$ & $-1,68$ & $-3,01$ & $-2,26$ & $-3,75$ & $-2,25$ \\
\hline Choques externos & & 1,84 & 6,37 & 7,40 & 7,86 & 6,43 & 5,98 \\
\hline Outras variáveis externas & & 0,77 & 0,43 & 0,87 & 1,90 & 1,65 & 1,12 \\
\hline Políticas domésticas & & $-0,54$ & $-4,80$ & $-7,19$ & $-7,15$ & $-10,73$ & $-6,08$ \\
\hline \multirow{3}{*}{$\begin{array}{c}\text { Saldo em transações } \\
\text { correntes }\end{array}$} & Calculado & 2,06 & 2,80 & 1,60 & 2,86 & $-0,74$ & 1,72 \\
\hline & Observado & 1,39 & 2,06 & 1,06 & 2,51 & $-0,04$ & 1,40 \\
\hline & Resíduo & 0,67 & 0,74 & 0,54 & 0,35 & $-0,70$ & 0,32 \\
\hline Setor agrícola & & 0,32 & $-0,65$ & $-0,72$ & 0,11 & $-2,13$ & $-0,61$ \\
\hline
\end{tabular}

Fonte: cálculos do autor.

1 Os fatores de decomposição foram calculados utilizando-se como pesos os valores observados para o ano base. 
$\left(\mathbf{P}_{\mathbf{x}} \mathbf{a} / \mathbf{P}_{\mathbf{y}}\right.$ de $0,40 \%$, em média) e o gasto doméstico ( $\mathbf{A}_{\mathbf{a}} / \mathbf{U}^{\prime}$ médio de $\left.0,03 \%\right)$ reduzem $\mathbf{o}$ auxílio final do setor. Note-se que $\mathbf{J}_{\mathbf{a}} / \mathbf{A}_{\mathbf{a}}$ foi positiva em 1979 (0,18\%) e $1980(0,17 \%)$, passando a negativa de $1981 \mathrm{em}$ diante. Enquanto isso, $\mathbf{P}_{\mathbf{x}} \mathbf{a} / \mathbf{P}_{\mathbf{y}}$ foi negativa nos mesmos anos: $-0,36 \%$ e $-0,70 \%$, respectivamente, passando a positiva também de 1981 em diante.

Os choques externos (média de 5,98\%) dão um salto entre 1979 $(1,84 \%)$ e 1980 (6,37\%), devido ao choque de preços de petróleo de 1979. O efeito dos preços da importações não-agrícolas $\left(\mathbf{P}_{\mathbf{m}} \mathbf{n} / \mathbf{P}_{\mathbf{y}}\right)$ é altíssimo: média qüinqüenal de $4,43 \%$ (saindo de 1,79\%, em 1979, para 5,55\%, em 1980, e atingindo 5,63\% em 1983). As relações de troca das exportações não-agrícolas $\left(\mathbf{P}_{\mathbf{x}} \mathbf{n} / \mathbf{P}_{\mathbf{y}}\right)$, embora em níveis mais modestos, também colaboram com a deterioração do saldo em transações correntes: média de 0,22\%, embora os valores tenham sido negativos em 1979 (-0,08\%), 1980 ($0,11 \%)$ e $1983(-0,11 \%)$.

Os outros dois tipos de choques externos também influenciaram o saldo em transações correntes. $O$ efeito das taxas de juros (r) (média de 0,97\%) intensificou-se a partir de 1980 (0,73\%). Em 1982, atingiu 1,63\% do PNB de aumento do déficit, em relação ao ano-base, caindo para $0,85 \%$ no ano seguinte. A variação do comércio mundial (W/U') colaborou para redução do déficit, mas perdeu importância relativa em comparação ao período anterior, 1974-1978, quando mostrou valores anuais de maior magnitude. $\mathrm{O}$ efeito dos dois setores foi pequeno $\left(\mathbf{W}_{\mathbf{a}} / \mathbf{U}^{\prime}\right.$ médio de $-0,19 \% \mathrm{e}$ $\mathbf{W}_{\mathbf{n}} / \mathbf{U}^{\prime}$ médio de -0,04\%). $\mathbf{W}_{\mathbf{a}} / \mathbf{U}^{\prime}$ apresentou um único valor positivo, 0,18\%, em 1980. $\mathbf{W}_{\mathrm{n}} / \mathbf{U}^{\prime}$ foi positivo em $1979(0,04 \%)$ e $1980(0,23 \%)$. A mudança de sinal, a partir de 1981, indica que a contração do comércio mundial é menos violenta do que a recessão brasileira, em particular para os mercados agrícolas. $\mathrm{O}$ valor somado $\left(\mathbf{W} / \mathbf{U}^{\prime}\right)$ atinge $0,99 \%$ em $1983\left(\mathbf{W}_{\mathbf{a}} / \mathbf{U}^{\prime}\right.$ de $\left.-0,58 \%\right)$.

O item outras variáveis externas teve efeito importante no aumento do déficit, contribuindo, em média, com $1,12 \%$ do PNB. O acúmulo da dívida externa líquida ( $\left.\mathrm{K} / \mathbf{Y}^{\prime}\right)$ mostrou-se crescente e positivo ao longo do período, com valores acima de $1,0 \%$ do PNB em 1982 (1,05\%) e 1983 (1,49\%), e média de 0,72\%. As outras rendas 
de capitais e trabalho $\left(\mathbf{V}_{\mathbf{d}} / \mathbf{Y}^{\prime}\right)$ apresenta valor médio de $0,40 \%$ (com um máximo de 0,90\%, em 1982). As transferências unilaterais (T/Y') exibem média ínfima: $0,00 \%$ (mínimo de -0,05\%, em 1982, e máximo de 0,04\%, em 1981).

As políticas domésticas apresentam valores que indicam o esforço de correção do déficit: média de $-6,08 \%$ do PNB. Os valores cresceram a o longo do tempo, passando de $-0,54 \%$, em 1979, para $-10,73 \%$, em 1983. O gasto doméstico (A/U') apresentou pequena contribuição ao aumento do déficit: $0,23 \%$ do PNB, em média ${ }^{35}$. $O$ setor não-agrícola respondeu pela parcela maior: $0,18 \%$ do $\mathrm{PNB}$, em média $\left(\mathbf{A}_{\mathbf{n}} / \mathbf{U}^{\prime}\right.$ máximo de 0,24\%, em 1982, e mínimo de 0,10\%, em 1981). O setor agrícola apareceu com meros $0,03 \%$, em média $\left(\mathbf{A}_{\mathbf{a}} / \mathbf{U}^{\prime}\right.$ máximo de $0,10 \%$, para 1981 ; mínimo de $-0,02 \%$, em 1980).

A competitividade externa participou com destaque do ajuste, com ênfase no setor não-agrícola. A substituição de importações $\left(\mathbf{J}_{\mathbf{n}} / \mathbf{A}_{\mathbf{n}}\right)$ e a penetração das exportações $\left(\mathbf{Z}_{\mathbf{n}} / \mathbf{W}_{\mathbf{n}}\right)$ não-agrícolas, representaram, respectivamente, $-3,00 \%$ e $-2,25 \%$ do PNB, em média. A soma dessas duas variáveis foi -1,26\% em $1979\left(\mathbf{J}_{\mathbf{n}} / \mathbf{A}_{\mathbf{n}}\right.$ de 0,72\%), -5,82\% em $1981\left(\mathbf{J}_{\mathbf{n}} / \mathbf{A}_{\mathbf{n}}\right.$ de -2,81\%) e -8,32\% em $1983\left(\mathbf{J}_{\mathbf{n}} / \mathbf{A}_{\mathbf{n}} \text { de }-4,57 \%\right)^{36}$.

A competitividade externa do setor agrícola $\left(\mathbf{J}_{\mathbf{a}} / \mathbf{A}_{\mathbf{a}}\right.$ e $\left.\mathbf{Z}_{\mathbf{a}} / \mathbf{W}_{\mathbf{a}}\right)$ ajudou igualmente a diminuir $\mathbf{o}$ déficit. A penetração das exportações agrícolas $\left(\mathbf{Z}_{\mathbf{a}} / \mathbf{W}_{\mathbf{a}}\right)$ mostrou valor médio de $-0,96 \%$, indicando elevação da competitividade externa. Os valores são crescentes: $0,32 \%$ em 1979, -1,52\% em 1981 e -1,86\% em 1983. O conteúdo das importações $\left(\mathbf{J}_{\mathbf{a}} / \mathbf{A}_{\mathbf{a}}\right)$ que, como visto acima, foi positivo em 1979 e 1980, e negativo de 1981 em diante (atingindo -0,75\% em 1983), adiciona mais uma evidência de que o

\footnotetext{
${ }^{35}$ Esse dado difere do encontrado por BACHA (1984, p.592), que foi de $-0,43$, em média, para o item "contração do produto", para o mesmo periodo. Porém, há diferenças entre os cálculos efetuados por Bacha e os do presente trabalho. A definição para o gasto doméstico envolve denominadores diferentes: há contração do produto efetivo (ora utilizado) em relação ao produto potencial (adotado por Bacha).

${ }^{36}$ O BACEN implementou a centralização do câmbio em 1983, com forte controle das importações.
} 
setor agrícola nacional realizou esforço de ajuste para a correção do déficit em transações correntes pois, conseguindo atender à demanda interna, evitou importações de alimentos.

\subsubsection{O subperíodo 1984-1988}

O ano-base da decomposição desse subperíodo é 1983. Os resultados estão na Tabela 7. A evolução do saldo em transações correntes em relação ao ano-base tem sinal negativo (calculado, $-3,24 \%$; observado, $-3,26 \%$ ). Isso denota a redução do déficit ao longo do período.

A colaboração da agricultura faz aumentar o déficit, em média (1,06\%), sendo favorável somente em 1984 (-0,79\%). A partir de 1985 (0,25\%), os valores mostram-se positivos, atingindo o máximo de $2,48 \%$ em 1986 , com $1,48 \%$ em 1988. A explicação é o mau desempenho das exportações agrícolas. A variação das relações de troca, $\mathbf{P}_{\mathbf{x}} \mathbf{a} / \mathbf{P}_{\mathbf{y}}$, atua contra a correção do déficit (média de $0,17 \%$, máximo de 0,88\%, em 1987, e mínima de $-0,91 \%$, em 1984), bem como a variação do comércio mundial (Wa/U', média de 0,69\%, máximo 1,00\%, em 1986; mínimo 0,10\%, em 1984), a substituição de importações $\left(\mathbf{J}_{\mathbf{a}} / \mathbf{A}_{\mathbf{a}}\right.$ médio de $0,37 \%$ e máximo de $1,17 \%$, em 1986 , e mínimo de $-0,13 \%$, em 1988$)$ e a penetração nos mercados mundiais $\left(\mathbf{Z}_{\mathbf{a}} / \mathbf{W}_{\mathbf{a}}\right.$, média de 0,41\%, com máximo de 1,27\%, em 1986, e mínimo de -0,30\%, em 1985). Auxiliam na redução do déficit apenas a variação das relações de troca $\mathbf{P}_{\mathbf{m}} \mathbf{a} / \mathbf{P}_{\mathbf{y}}$ (média de $-0,58 \%$, máximo de -0,24\%, em 1984, e mínimo de -1,02\%, em 1986) e o gasto doméstico $\mathbf{A}_{\mathbf{a}} / \mathbf{U}^{\prime}$ (média de -0,01\%, com máximo de 0,04\%, em 1985, e mínimo de -0,05\%, em 1984).

Os choques externos são favoráveis ao ajuste (média de $-4,19 \%$, com máximo de $-2,94 \%$ em 1985 , e mínimo de -6,22\%, em 1986), graças, principalmente, à redução nos preços de petróleo, o que leva os termos de troca das importações nãoagrícolas $\left(\mathbf{P}_{\mathbf{m}} \mathbf{n} / \mathbf{P}_{\mathbf{y}}\right)$ a atingirem valor médio de $-3,16 \%$ (máximo de $-2,38 \%$, em 1984, e mínimo de -4,93\%, em 1986). Também os termos de troca das exportações não-agrícolas $\left(\mathbf{P}_{\mathbf{X}} \mathbf{n} / \mathbf{P}_{\mathbf{y}}\right.$ médio de $-0,05 \%$, com máximo de $0,53 \%$, em 1984 , e mínimo de $-0,79 \%$, em 
1987) e das importações agrícolas ajudam a contenção do déficit. As taxas de juros, em queda, colaboram firmemente: média de $-1,14 \%$, e máximo de $-0,45 \%$, em 1984 , e mínimo de -1,76\%, em 1987.

Tabela 7. Brasil. Decomposição ${ }^{1}$ das variações dos saldos em conta corrente, entre cada ano no período 1984/88 e o ano-base de 1983 (todas as variáveis são proporções do PNB). Base de preços 1971-73.

\begin{tabular}{|c|c|c|c|c|c|c|c|}
\hline Fatores explicativos & & 1984 & 1985 & 1986 & 1987 & 1988 & Média \\
\hline \multicolumn{8}{|l|}{ Choques externos } \\
\hline \multirow[t]{4}{*}{ Variação das relações de troca } & $\mathbf{P}_{\mathbf{m}} \mathbf{a} / \mathbf{P}_{\mathbf{y}}$ & $-0,24$ & $-0,32$ & $-1,02$ & $-0,79$ & $-0,53$ & $-0,58$ \\
\hline & $\mathbf{P}_{\mathbf{m}} \mathbf{n}_{\mathbf{P}} \mathbf{y}_{\mathbf{y}}$ & $-2,38$ & $-2,58$ & $-4,93$ & $-3,07$ & $-2,83$ & $-3,16$ \\
\hline & $\mathbf{P}_{\mathbf{x}} \mathbf{a}^{\mathbf{a}} \mathbf{P}_{\mathbf{y}}$ & $-0,91$ & 0,10 & 0,07 & 0,88 & 0,73 & 0,17 \\
\hline & $P_{x} n_{/} P_{y}$ & 0,53 & 0,12 & $-0,38$ & $-0,79$ & 0,25 & $-0,05$ \\
\hline Taxa de juros & $\mathbf{r}$ & $-0,45$ & $-0,82$ & $-1,15$ & $-1,76$ & $-1,51$ & $-1,14$ \\
\hline \multirow[t]{2}{*}{ Variação do comércio mundial } & $\mathbf{W}^{\mathbf{a}} / \mathbf{U}^{\prime}$ & 0,10 & 0,63 & 1,00 & 0,99 & 0,74 & 0,69 \\
\hline & $\mathbf{W}^{\mathbf{n}} / \mathbf{U}^{\prime}$ & $-0,34$ & $-0,07$ & 0,20 & 0,13 & $-0,55$ & $-0,13$ \\
\hline \multirow[t]{3}{*}{ Outras variáveis externas } & $\mathbf{K} / \mathbf{Y}^{\prime}$ & 0,56 & 0,36 & $-0,20$ & $-0,15$ & $-0,49$ & 0,02 \\
\hline & $\mathbf{V}_{\mathbf{d}} / \mathbf{Y}^{\prime}$ & $-0,50$ & $-0,50$ & $-0,32$ & $-0,66$ & $-0,64$ & $-0,52$ \\
\hline & $\mathbf{T} / \mathbf{Y}^{\prime}$ & 0,03 & 0,01 & $-0,02$ & $-0,03$ & $-0,03$ & $-0,01$ \\
\hline \multicolumn{8}{|l|}{ Políticas Domésticas } \\
\hline \multirow[t]{2}{*}{ Gasto doméstico } & $\mathbf{A}_{\mathbf{a}} / \mathbf{U}^{\prime}$ & $-0,05$ & 0,04 & $-0,01$ & 0,01 & $-0,02$ & $-0,01$ \\
\hline & $\mathbf{A}_{\mathbf{n}^{\prime \prime}} / \mathbf{U}^{\prime}$ & $-0,28$ & $-0,39$ & $-0,21$ & $-0,33$ & $-0,39$ & $-0,32$ \\
\hline \multirow[t]{4}{*}{ Competitividade externa } & $\mathbf{J}_{\mathbf{a}} / \mathbf{A}_{\mathbf{a}}$ & 0,31 & 0,11 & 1,17 & 0,39 & $-0,13$ & 0,37 \\
\hline & $J_{n} / A_{n}$ & 1,44 & 1,02 & 2,10 & 0,56 & $-0,71$ & 0,88 \\
\hline & $\mathbf{z}_{\mathbf{a}} / \mathbf{W}_{\mathbf{a}}$ & $-0,01$ & $-0,30$ & 1,27 & 0,40 & 0,69 & 0,41 \\
\hline & $\mathbf{z}_{\mathbf{n}} / \mathbf{w}_{\mathbf{n}}$ & $-1,72$ & $-1,08$ & 1,59 & 1,65 & 0,20 & 0,13 \\
\hline Choques externos & & $-3,68$ & $-2,94$ & $-6,22$ & $-4,42$ & $-3,71$ & $-4,19$ \\
\hline Outras variáveis externas & & 0,09 & $-0,13$ & $-0,54$ & $-0,84$ & $-1,15$ & $-0,51$ \\
\hline Políticas domésticas & & $-0,31$ & $-0,61$ & 5,91 & 2,68 & $-0,36$ & 1,46 \\
\hline \multirow{3}{*}{$\begin{array}{c}\text { Saldo em transações } \\
\text { correntes }\end{array}$} & Calculado & $-3,90$ & $-3,67$ & $-0,85$ & $-2,58$ & $-5,22$ & $-3,24$ \\
\hline & Observado & $-3,56$ & $-3,43$ & $-1,50$ & $-3,04$ & $-4,79$ & $-3,26$ \\
\hline & Resíduo & $-0,34$ & $-0,24$ & 0,64 & 0,46 & $-0,43$ & 0,02 \\
\hline Setor agrícola & & $-0,79$ & 0,25 & 2,48 & 1,88 & 1,48 & 1,06 \\
\hline
\end{tabular}

Fonte: cálculos do autor.

1 Os fatores de decomposição foram calculados utilizando-se como pesos os valores observados para o ano base. 
O subperíodo 1984-1988 é o que demonstra maior diferença de comportamento do comércio mundial para os dois setores (agrícola e não-agrícola). Ocorre, em média, aumento relativo do tamanho dos mercados não-agrícolas. $\mathbf{W} \mathbf{n} / \mathbf{U}^{\prime}$ tem média de $-0,13 \%$, e valor máximo atingindo $0,20 \%$, em 1986 , e mínimo $-0,55 \%$, em 1988. O comércio mundial de produtos agrícolas contribui para o aumento do déficit, com Wa/U' médio de 0,69\%, e atingindo $1,00 \%$ em 1986 e $0,99 \%$ em 1987.

As outras variáveis externas auxiliam, em média $(-0,51 \%)$, a redução do déficit (valor máximo de $0,09 \%$, em 1984, e mínimo de $-1,15 \%$, em 1988). O destaque fica por conta das outras rendas de capitais e trabalho $\left(\mathbf{V}_{\mathbf{d}} / \mathbf{Y}^{\prime}\right)$ com média de 0,52\% (máximo de -0,32\%, em 1986, e mínimo de -0,66\%, em 1987). As transferências unilaterais, $\mathbf{T} / \mathbf{Y}^{\prime}$, a exemplo do subperíodo anterior, mostraram valores extremamente reduzidos (média de $-0,01 \%)$. $\mathrm{O}$ acúmulo da dívida externa líquida $\left(\mathbf{K} / \mathbf{Y}^{\prime}\right)$ teve impacto médio reduzido $(0,02 \%)$, mas com muita variação nos cinco anos considerados. $\mathrm{O}$ sinal foi positivo em 1984 (0,56\%) e 1985 (0,36\%), passando a negativo em 1986 (-0,20\%), $1987(-0,15 \%)$ e $1988(-0,49 \%)$. Isso quer dizer que, embora a dívida externa estivesse aumentando ao longo de todo o subperíodo, sua elevação foi inferior ao crescimento do PNB, nos três últimos anos, colaborando, assim, para a redução do déficit.

As políticas domésticas (média de $1,46 \%$ ) contribuem ao processo de ajuste em $1984(-0,31 \%)$ e $1985(-0,61 \%)$, mas ajudam a deterioração das contas de transações correntes em 1986 (5,91\%) e em 1987 (2,68\%). Tal fato resulta da expansão da demanda interna a partir do Plano Cruzado. Em 1988, ocorre um fraco ajuste ($0,36 \%)$, através do gasto doméstico $(-0,41 \%)$ e das substituições de importações ($0,84 \%)$, embora a penetração das exportações tenha ido no sentido contrário $(0,89 \%)$.

O subperíodo 1984-1988 é o único em que o gasto doméstico tem valores negativos $\left(\mathbf{A}_{\mathbf{n}} / \mathbf{U}^{\prime}\right.$ médio de -0,32\%, com máximo de -0,21\%, em 1986, e mínimo de $-0,39 \%$, em 1985 e 1988, e $\mathbf{A}_{\mathbf{a}} / \mathbf{U}^{\prime}$ médio de $-0,01 \%$ ), devido à queda da taxa de investimento da economia, posto que os demais indicadores (conteúdo das importações, 
penetração das exportações) evidenciam que o consumo interno não decresce, em especial a partir de 1986.

Até 1985 , persiste o modelo econômico calcado na substituição de importações e na promoção de excedentes exportáveis, e que consegue razoável sucesso quanto ao controle do saldo em contas correntes (US\$ 44,8 milhões, em 1984, e -US\$ 241,5 milhões, em 1985, contra -US\$ 6,837 bilhões, em 1983). A partir de 1986, abandona-se a estratégia de combate à restrição externa via obtenção de excedentes comerciais. Isso fica claro ao se constatar que as variáveis referentes à competitividade externa do setor exportador, penetração das exportações $\left(\mathbf{Z}_{\mathbf{a}} / \mathbf{W}_{\mathbf{a}}\right.$, média de $0,41 \%$, e $\mathbf{Z}_{\mathbf{n}} / \mathbf{W}_{\mathbf{n}}$, média de $0,13 \%$ ), mudam de sinal, negativo em 1984 e 1985, para positivo, de 1986 em diante. $\mathbf{Z}_{\mathbf{n}} / \mathbf{W}_{\mathbf{n}}$ passa de $-1,72 \%$, em 1984 , para $-1,08 \%$, em $1985 ; 1,59 \%$, em 1986, e 1,65\%, 1987, fazendo aumentar o déficit, nestes dois últimos anos. Eleva-se o conteúdo de importações $\left(\mathbf{J}_{\mathbf{a}} / \mathbf{A}_{\mathbf{a}}\right.$ médio de $0,37 \%$, e $\mathbf{J}_{\mathbf{n}} / \mathbf{A}_{\mathbf{n}}$ médio de $\left.0,88 \%\right)$. Em 1988, há sinais de retomada do ajuste, com valores negativos para o conteúdo importações agrícolas ( $\mathbf{J}_{\mathbf{a}} / \mathbf{A}_{\mathbf{a}}$ de -0,13\%) e não-agrícolas $\left(\mathbf{J}_{\mathbf{n}} / \mathbf{A}_{\mathbf{n}}\right.$ de -0,71\%), e redução na perda de penetração das exportações não-agrícolas $\left(\mathbf{Z}_{\mathbf{n}} / \mathbf{W}_{\mathbf{n}}\right.$ de $\left.0,20 \%\right)$.

\subsubsection{A contribuição do setor agrícola}

Uma visão global do período 1973-1988 (ver Tabela 8) mostra que a contribuição direta do setor agrícola para a redução do déficit em conta corrente acontece somente no qüinqüênio 1979-1983. Entre 1974 e 1978, a agricultura auxiliou a deterioração do saldo em transações correntes do balanço de pagamentos, pois sua participação no déficit aumentou ao longo do período: foi de 1,52\%, em 1974, para $2,34 \%$, em 1978, com média qüinqüenal de $1,63 \%$.

O melhor desempenho ocorreu entre 1979 e 1983, com média de 0,61\%, destacando-se $1980(-0,65 \%), 1981$ (-0,72\%) e $1983(-2,13 \%)$. O período 19841988, embora tenha tido contribuição total para aumentar o déficit, com média de $1,06 \%$, 
ainda mostrou, em 1984 (-0,79\%), participação na redução do déficit. Em 1979, 1982 e 1985, o setor agrícola pressionou levemente o aumento do déficit de transações correntes: $0,32 \%, 0,11 \%$ e $0,25 \%$, respectivamente. De 1986 a 1988 , essa situação modificou-se: enquanto os termos de troca das importações $\left(\mathbf{P}_{\mathbf{m}} / \mathbf{P}_{\mathbf{y}}\right)$, com média de $4,39 \%$, e taxas de juros (r), com média de $-1,47 \%$, permitem a manutenção dos saldos sob relativo controle (ver Tabela 7), o setor agrícola concorre para aumentá-lo (com $2,48 \%$ em 1986, 1,88\% em 1987 e 1,48\% em 1988, e média trienal de 1,95\%).

Tabela 8. Brasil. 1974 a 1988. Contribuição do setor agrícola ao ajuste do saldo em conta corrente do balanço de pagamentos, em porcentagem do PNB. Valores anuais e médias aritméticas qüinqüenais.

\begin{tabular}{ccc}
\hline Ano & Valor & Média qüinqüenal \\
\hline 1974 & 1,52 & \\
1975 & 2,10 & \\
1976 & 1,47 & 1,63 \\
1977 & 0,73 & \\
1978 & 2,34 & \\
1979 & 0,32 & \\
1980 & $-0,65$ & $-0,61$ \\
1981 & $-0,72$ & \\
1982 & 0,11 & \\
1983 & $-2,13$ & \\
1984 & $-0,79$ & 1,06 \\
1985 & 0,25 & \\
1986 & 2,48 & \\
1987 & 1,88 & \\
1988 & 1,48 & \\
\hline
\end{tabular}

Fonte: Tabelas 5 a 7 (cálculos do autor).

A Tabela 9 ajuda a responder a uma das questões investigadas na presente pesquisa: a contribuição do setor agrícola ao ajuste do setor externo da economia brasileira se deu através da substituição de importações, ou da expansão das 
exportações? A hipótese adotada é de que a caracterização no sentido da preponderância de uma ou de outra estratégia não se verificou, ao longo do período 1973 a 1988. Essa verificação pode ser feita através da análise dos efeitos das políticas macroeconômicas sobre o setor agrícola, ilustrados, nas Tabelas 5 a 7, nos seguintes indicadores do grupo "políticas domésticas": gasto doméstico agrícola como proporção do PNB, mostrando como o setor contribuiu em termos de redução da demanda interna $\left(\mathbf{A}_{\mathbf{a}} / \mathbf{U}^{\prime}\right)$; importações agrícolas como proporção do gasto doméstico agrícola, indicando o processo de substituição de importações no setor $\left(\mathbf{J}_{\mathbf{a}} / \mathbf{A}_{\mathbf{a}}\right)$ e a participação das exportações agrícolas nacionais em relação ao respectivo mercado mundial, representando a penetração das exportações agrícolas $\left(\mathbf{Z}_{\mathbf{a}} / \mathbf{W}_{\mathbf{a}}\right)$.

Tabela 9. Brasil. 1974 a 1988. Contribuição das políticas agrícolas domésticas ao ajuste do saldo em conta corrente do balanço de pagamentos. Médias aritméticas qüinqüenais.

\begin{tabular}{lrrrrr}
\hline & & $1974 / 78$ & $1979 / 83$ & $1984 / 88$ & Média do Total \\
\hline $\mathbf{A}_{\mathbf{a}} / \mathbf{U}^{\prime}$ & $(1)$ & 0,04 & 0,03 & $-0,01$ & 0,02 \\
$\mathbf{J}_{\mathbf{a}} / \mathbf{A}_{\mathbf{a}}$ & $(2)$ & $-0,10$ & $-0,10$ & 0,37 & 0,06 \\
$\mathbf{Z}_{\mathbf{a}} / \mathbf{W}_{\mathbf{a}}$ & $(3)$ & 0,52 & $-0,96$ & 0,41 & $-0,01$ \\
$\mathbf{T o t a l}$ & $(\mathbf{1}+(\mathbf{2})+(3)$ & 0,46 & $-1,03$ & 0,77 & 0,07 \\
\hline
\end{tabular}

Fonte: Tabelas 5 a 7.

Uma análise qualitativa, variável por variável, da Tabela 9, dá um resultado que não rejeita a hipótese testada. Dos nove sinais, quatro são negativos e cinco, positivos (sinal negativo indica redução do déficit em conta corrente). $\mathrm{O}$ esforço do setor agrícola na contenção do déficit é, em primeiro lugar (1974/78), por meio da substituição de importações; a seguir (1979/83), há destacada colaboração da penetração 
das exportações. Por fim (1984/88), o ajuste só ocorre através da redução da demanda interna.

A diferença na magnitude dos valores indica que o ajuste ocorreu, de modo mais perceptível, através das medidas relacionadas à substituição de importações ou penetração das exportações (os valores referentes ao gasto doméstico, por período, são bem próximos de zero, com reduzida variação). A substituição de importações contribui para a redução do déficit nos dois primeiros períodos e, a penetração das exportações, somente no último. Na média do período 1974 a 1988, todavia, nota-se que as políticas domésticas, em termos de setor agrícola, afetaram muito pouco o déficit em conta corrente. $\mathrm{O}$ maior efeito foi da substituição de importações (média de 0,06), para 0 aumento do déficit. A penetração das exportações colabora com reduzidos $-0,01$ para a redução do déficit. Assim, à luz da metodologia adotada, e em termos do ajuste do déficit em transações correntes do balanço de pagamentos, a contribuição da agricultura, para 0 período todo, não sobressaiu nem quanto à substituição de importações, nem quanto à penetração das exportações.

Não há um padrão definido para o comportamento das políticas agrícolas domésticas. Para o total por períodos, o sinal é positivo em 1974/78, negativo em 1979/83, e novamente positivo em 1984/88. A média do período todo é de 0,067 -muito próximo de zero. Isso indica contribuição praticamente neutra do setor quanto à correção do déficit, tomando todo o período 1973 a 1988. Segundo os critérios da presente pesquisa, a contribuição da agricultura ao ajuste da economia frente aos choques externos foi praticamente irrelevante, em que pese tenha havido contribuição significativa em certos anos específicos. 


\section{CONCLUSÕES}

Esta pesquisa enfoca a economia brasileira entre 1973 e 1988. Foi analisada, com o auxilio de informações quantitativas, a contribuição do setor agrícola ao ajuste interno frente à crise de origem externa.

A principal restrição das contas nacionais referia-se às transações com o exterior. Assim, considerou-se que a agricultura poderia ter auxiliado o ajuste via abastecimento interno (qual seja, substituindo importações), ou através do incremento das exportações (com geração de excedentes comerciais).

A hipótese de trabalho adotada foi de que esse direcionamento para um ou outro mercado não chegou a se caracterizar de modo definitivo. A hipótese não foi rejeitada, considerado o período inteiro. Todavia, quando se consideram subperíodos, a contribuição do setor agrícola ao controle do déficit em conta corrente mostra o seguinte padrão: para o subperíodo 1974-1978, mais forte através da substituição de importações; entre 1979 e 1983, de modo mais destacado via penetração das exportações e, para 1984-1988, nenhuma das duas op̧̧ões sobressai.

A literatura específica sobre a interação agricultura/ajuste concentra-se em alguns pontos. LOPES (1989) realça o fato de as políticas comercial, macro e cambial discriminarem contra o setor exportador agrícola, ao longo das últimas duas décadas. Tal fato teria induzido a agricultura brasileira a atuar voltada para o mercado interno. REZENDE aponta que os preços externos, desestimulantes, também colaboraram para o direcionamento à produção de não-tradables na década de 80. DIAS ressalta que a efetiva contribuição da agropecuária ao ajuste ocorreu através do fornecimento de alimentos baratos, evitando a queda de salários reais, a partir do momento em que se 
incentivou a geração de excedentes comerciáveis. Isso teria permitido ao setor industrial realizar o esforço exportador.

Esses autores argumentam em torno da maior importância de um ou outro fator explicativo do comportamento do setor agrícola, dado um contexto global de ajustamento. Não se busca estimar o desempenho da agricultura em relação ao restante da economia, durante o processo de elevação e controle do déficit em transações correntes do balanço de pagamentos. Nesse sentido, a presente pesquisa se constitui em uma primeira abordagem quantitativa da participação do setor agrícola nas contas externas brasileiras.

As evidências empíricas deste trabalho mostram que a contribuição do setor agrícola só foi superavitária no período 1980/1984 (o valor para 1982 é positivo, porém muito próximo de zero). Além disso, os números dessa participação são pequenos, quando comparados àqueles referentes ao restante da economia. A agricultura toma parte da pauta de exportações com valores que, grosso modo, variam entre dois terços, no começo dos anos 70, até um terço, no final dos anos 80 . No ajuste através do incremento das exportações, a contribuição do setor agrícola foi, ao longo do tempo, menor, em relação à participação do setor não-agrícola. $O$ setor não-agrícola demonstrou grande esforço de ajuste através da geração de divisas estrangeiras.

As alterações nos totais das importações agrícolas redundaram em leve impacto na correção do déficit em transações correntes (exceto nos anos de 1983 e 1986). Na época do esforço maior de ajuste (final dos anos 70 e início dos anos 80), o setor não-agrícola teve grande contribuição por meio do decréscimo dos montantes importados. A substituição das importações, iniciada durante o II PND, atingiu inicialmente as importações não-agrícolas (a partir de 1976) e, logo após, as importações agrícolas, com o aumento da produção interna de trigo e de insumos.

O desempenho da agricultura mostra que o viés exportador não se configurou tão forte como aparentaria uma visão preliminar da pauta de exportações no período. $\mathrm{O}$ valor da disponibilidade doméstica da produção agropecuária aumentou cerca de 75\% entre 1971 e 1988 (DIAS, 1990). As causas disso seriam as políticas macroeconômicas (por exemplo, a política cambial), discriminatórias ao setor exportador agrícola. Tais políticas teriam, inclusive, neutralizado as medidas específicas de incentivo 
às exportações agropecuárias (a quantificação estimada nesta pesquisa vai ao encontro desse diagnóstico).

As exportações agrícolas brasileiras mantiveram sua participação relativa no comércio mundial durante o período. Aumentou a parcela de produtos agroindustriais no total de exportações agrícolas, a despeito de alguns fatores contrários. Além dos fatores de origem interna, apontados no parágrafo anterior, há um importante fator contrário extemo. No subperíodo 1981-83, os termos de troca das exportações agrícolas apresentavam-se desfavoráveis e, mesmo assim, houve uma expansão relativa do comércio mundial da agricultura superior ao do setor não-agrícola.

No âmbito interno, não ocorreram grandes variações na absorção de produtos agrícolas. A produção doméstica atendeu o consumo, com reduzidas (ou até negativas) pressões importadoras. O decréscimo das importações agrícolas, em 1981/83, é um indicador de que o setor agrícola conseguiu atender ao suprimento da demanda interna. Durante os anos 80 , a maior queda na absorção refere-se ao setor não-agrícola, reflexo do menor volume de investimentos e da redução no crescimento da economia nacional.

O ajuste no período 1984/88 caracterizou-se pela queda dos termos de troca das importações e da taxa de juros. Comparativamente, o ajuste do gasto doméstico foi inexpressivo, e o modelo exportador deixou de atuar no sentido do controle do déficit a partir de 1986. A economia brasileira estava, no fim do período, suscetível a choques de preços de origem externa.

Numa visão global, a fragilidade da economia brasileira frente a qualquer choque de preços exógeno fica evidenciada pelo fato de que a política econômica adotada para o ajuste não se consolida como um novo padrão de crescimento, de maior abertura do setor externo. $O$ déficit só se mantém sob controle devido à redução dos termos de troca das importações. A partir de 1986, o aumento do consumo doméstico provoca a expansão do produto nacional. Esse aumento é possibilitado pela redução das restrições que visavam obter um saldo de transações correntes mais equilibrado. Nesse sentido, a reversão do comportamento dos termos de troca das importações ou uma recessão do comércio mundial poderiam provocar efeitos negativos na economia brasileira. 


\section{REFERÊNCIAS BIBLIOGRÁFICAS}

Alves, E. \& Contini, E. Progresso tecnológico e desenvolvimento da agricultura brasileira. In: SEMINÁRIO DE PROBLEMAS E PERSPECTIVAS DA AGRICULTURA, 3, Piracicaba, 1987. Anais. Piracicaba, FEALQ, 1987. p. 39-56.

Alves, E. \& Contini, E. A modemização da agricultura brasileira. In BRANDÃo, A.S.P., ed. Os principais problemas da agricultura brasileira: análise e sugestões. Rio de Janeiro, IPEA/INPES, 1988. p. 49-98.

Anuário Estatístico. Associação Nacional dos Fabricantes de Veículos AUTOMOTORES. 1957/1988. São Paulo, 1989. 107 p.

BACHA, E. L. Choques externos e perspectivas de crescimento: o caso do Brasil 1973/89. Pesquisa e Planejamento Econômico, Rio de Janeiro, 14 (3): 583-622, dez. 1984.

BACHA, E. L. Contabilidade dos choques externos: o caso da América Latina - 1978/82. Pesquisa e Planejamento Econômico, Rio de Janeiro, 15 (2): 261-76, ago. 1985.

BALANÇA COMERCIAL e outros indicadores conjunturais. Rio de Janeiro. (vários números)

BALASSA, B. Reações de políticas econômicas aos choques externos em alguns países latino-americanos. Estudos Econômicos, São Paulo, 11 (2): 17-49, abr.jun. 1981.

BALASSA, B. et alii. The balance of payment effects of external shocks and of policy responses to these shocks. Paris, OCDE, 1981. 
BALASSA, B. \& MCCARTHY, F.D. Adjustment policies in developing countries, 1979-83: an update. World Bank Staff Working Papers, (675), 1984.

BAtista JR., P.N. et al. Fundação Getúlio Vargas. Ensaios sobre o setor externo da economia brasileira. Rio de Janeiro, 1981. 212p.

BARROS, G.S. de C. Efeitos de choques macroeconômicos sobre a transmissão de preços agrícolas. In: CONGRESSO BRASILEIRO DE ECONOMIA E SOCIOLOGIA RURAL, 24, Lavras, 1986. Anais. Brasília, SOBER, 1986, v. 1, p.245-59.

BARROS, J.R.M., \& MANOEL, A. Insumos agrícolas: evolução recente e perspectivas. In BRANDÃO, A.S.P., ed. Os principais problemas da agricultura brasileira: análise e sugestões. Rio de Janeiro, IPEA/INPES, 1988. p. 295-332.

BenEVEnUto, A. Agricultura de mercado interno versus agricultura de exportação: caracterização e tendências. In: CONGRESSO BRASLlLIRO DE ECONOMIA E Sociologia Rural, 27, Piracicaba, 1989. Anais. Brasília, SOBER, 1989, v. 1, p. 610-34.

BRASIL. Banco Central do Brasil. Boletim mensal. Brasília.

CARValHo, J.L. Choques externos e resposta interna: "semeando vento e colhendo tempestade" na agricultura brasileira. Revista Brasileira de Economia, Rio de Janeiro, 43 (2): 139-77, abr./jun. 1989.

CAstro, A.B. \& SouZA, F.E.P. A economia brasileira em marcha forçada. Rio de Janeiro: Paz e Terra, 1985.

COMÉRCIO EXTERIOR DO BRASIL; EXPORTAÇÃO. Brasília, Secretaria da Receita Federal, Coordenação do Sistema de Informações Econômico-Fiscais, 1972.

COMÉRcIo EXTERIOR DO BRASIL; IMPORTAÇÃo. Brasília, Secretaria da Receita Federal, Coordenação do Sistema de Informações Econômico-Fiscais, 1972.

CRUZ, P.D. Dívida externa e política econômica - a experiência brasileira nos anos setenta. São Paulo, Brasiliense, 1984. 188 p. 
DALL'ACQUA, F.M. Impacto macroeconómico del programa de ajuste sobre el sector agrícola en el Brasil 1979-1984. In: IICA Ajuste macroeconómico y sector agropecuario en America Latina. Buenos Aires, ICA, 1988.

DELGADO, G.C. \& FONSECA, R.B. Balanço de transações correntes do setor agrícola 1972/79. Brasília, IPL.AN/IPEA, 1980. (Relatório inicial de pesquisa).

DIAS, G.L. da S. O papel da agricultura no processo de ajustamento - notas adicionais. In: Congresso Brasileiro de Economia e Sociologia Rural, 27, Piracicaba, 1989. Anais... Brasília, SOBER, 1989, v. 2, p. 310-17.

DoRnBusCH, R. As dívidas dos países em desenvolvimento. Revista de Economia Política, São Paulo, 8(1):14-47, jan-mar. 1988.

ENDO, S.K. Números Índices. São Paulo: Atual, 1988.

GATT. INTERNATIONAL TRADE. Geneva. (vários números)

GoldENSTEIn, S. A dívida externa brasileira - 1964-1982, evolução e crise. Rio de Janeiro, Guanabara, 1986. 169 p.

JANK, M. Mudanças no padrão de crescimento e dinâmica do ajuste externo do setor agroindustrial. In: CONGRESSO BRASLEIRO DE ECONOMIA E SOCIOLOGIA RURAL, 28, Florianópolis, 1990. Anais. Brasília, SOBER, 1990, v. 1, p. 297-308.

JOHNSON, D.G. Trade liberalisation and other desirable agricultural policies. In: Seminário Internacional de POlítica Agrícola, São Paulo, 1988. Anais. São Paulo, IEA, 1988.

LOPES, M. R. As políticas macroeconômicas e o setor agrícola. In: SEMINÁRIO DE PRoblemas e Perspectivas da agricultura, 3, Piracicaba, 1987. Anais ... Piracicaba, FEALQ, 1987. p. 57-66.

LOPES, M. R. Os efeitos das políticas macroeconômicas sobre a agricultura. Brasília, Companhia de Financiamento da Produção, 1989. 69 p.(Coleção Análise e Pesquisa, 37). 
MACEDO, R. et alii. Sair da crise: uma análise dos problemas econômicos atuais e diretrizes para enfrentá-los. São Paulo, Instituto Brasileiro de Capacitação Bancária, 1988. $146 \mathrm{p}$.

MELO, F.H. de. Prioridade agrícola: sucesso ou fracasso? São Paulo, FIPE/Pioneira, 1985.

MELO, F.H. de. Um diagnóstico sobre produção e abastecimento alimentar no Brasil. In: SEMINÁRIo INTERNACIONAL DE POLÍTICA AGRÍCOLA, São Paulo, 1988. Anais. São Paulo, IEA, 1988.

OliVeIRA, J. C. Incidência da taxação implícita sobre produtos agrícolas no Brasil: 1950/74. Pesquisa e Planejamento Econômico, Rio de Janeiro, 14(2): 399-42, ago. 1984.

OliveirA, J. C. Transferência de recursos da agricultura no Brasil: 1950-1974. Pesquisa e Planejamento Econômico, Rio de Janeiro, 14(3): 823-50, dez. 1984.

REZENDE, G.C. Ajuste externo e agricultura no Brasil, 1981-86. Revista Brasileira de Economia, Rio de Janeiro, 42(2): 101-37, abr.-jun. 1988.

REZENDE, G.C. Política econômica e agricultura na década de oitenta. In: CONGRESSO Brasileiro de Economia e Sociologia RuRal, 27, Piracicaba, 1989. Anais. Brasília, SOBER, 1989, v. 2, p. 284-309.

REZENDE, G.C. Agricultura e ajuste externo no Brasil: uma análise adicional. Rio de Janeiro, IPEA/INPES, 1990. (Mimeo)

SIMONSEN, M.H., \& CYSNE, R.P. Balanço de pagamentos. Rio de Janeiro, Fundação Getúlio Vargas, 1986.

SOARES, F.B. A política agrícola da Comunidade Econômica Européia. In: SEMINÁRIO DE PROBLEMÁS E PERSPECTIVAS DA AGRICUlTURA, 4, Piracicaba, 1988. Anais. Piracicaba, FEALQ, 1988. p.169-189. 
SOARES, F.B. Três décadas de política agrícola na CEE: êxitos e fracassos. In: SEMINÁRIO De PROBlemas E PERSPeCtiVAS DA AGRICUltURA, 5, Piracicaba, 1989. Anais ... Piracicaba, FEALQ, 1989. p. 49-62.

STOCK, L.A., et alii. O mercado de insumos agrícolas modernos: experiência, demanda e difusão. Pesquisa e Planejamento Econômico, Rio de Janeiro, 14(3): 823-50, dez. 1984.

THE WORLD BANK. Brazil agricultural sector review: policies and prospects. June 29, 1989. (Report no 3305-BR).

WORLD DEVELOPMENT REPORT, 1986. New York, Oxford University Press, 1986. 256 p.

ZINI JÚNIOR, A.A. As minidesvalorizações brasileiras: política adequada com choques de oferta? Estudos Econômicos, São Paulo, 18(1): 51-91, jan./abr. 1988.

ZINI JÚNIOR, A.A. O Brasil num cruzamento: dívida externa e exaustão fiscal. Revista de Economia Política, São Paulo, 10(1): 32-52, jan-mar. 1990. 


\section{APÊNDICE 1}




\section{SUMÁRIO}

\section{LISTA DE TABELAS}

Página

Tabela 1. Mundo. Exportações de mercadorias. Valores totais (em bilhões 71 de dólares). Quantidades e Preços (Índices).

Tabela 2. Brasil. Contas Nacionais, 1971-1988.

72

Tabela 3. Brasil. Balanço de Pagamentos, em milhões de dólares. 1970 a 73 1988.

Tabela 4. Brasil. Comércio Exterior, 1971 a 1988, Valores em US\$1000 74 (FOB).

Tabela 5. Brasil. Exportações. Agricultura. 1971-1979. Valores correntes, 75 em US\$1000 (FOB).

Tabela 6. Brasil. Exportações. Agricultura. 1980-1988. Valores correntes, 77 em US\$1000 (FOB).

Tabela 7. Brasil. Exportações. Agricultura. 1971-1979. Quantidades (em 79 toneladas).

Tabela 8. Brasil. Exportações. Agricultura. 1980-88. Quantidades (em 81 toneladas).

Tabela 9. Brasil. Exportações não-agrícolas. 1971-1979. Valores correntes, 83 em US\$1000 (FOB).

Tabela 10. Brasil. Exportações não-agrícolas. 1980-1988. Valores 85 correntes, em US\$1000 (FOB).

Tabela 11. Brasil. Exportações não-agrícolas. 1971-1979. Quantidades (em 87 toneladas).

Tabela 12. Brasil. Exportações não-agrícolas. 1980-1988. Quantidades (em 89 toneladas).

Tabela 13. Brasil. Importações. Agricultura. 1971-1979. Valores correntes, 91 em US\$1000 (FOB).

Tabela 14. Brasil. Importações. Agricultura. 1980-1988. Valores correntes, 93 em US\$1000 (FOB). 
Tabela 15. Brasil. Importações. Agricultura. 1971-1979. Quantidades (em 95 toneladas).

Tabela 16. Brasil. Importações. Agricultura. 1980-88. Quantidades (em 97 toneladas).

Tabela 17. Brasil. Importações não-agrícolas. 1971-1979. Valores 99 correntes, em US\$1000 (FOB).

Tabela 18. Brasil. Importações não-agrícolas. 1980-1988. Valores 101 correntes, em US\$1000 (FOB).

Tabela 19. Brasil. Importações não-agrícolas. 1971-1979. Quantidades (em 103 toneladas).

Tabela 20. Brasil. Importações não-agrícolas. 1980-1988. Quantidades (em 105 toneladas).

Tabela 21. Brasil. Absorção. 1971-88 (valores em US\$1000).

107

Tabela 22. Brasil. Valor da Disponibilidade Doméstica (VDD) da produção 108 agropecuária nacional e Grau de Abertura (GA), 1962 a 1988 (base: 1988).

Tabela 23. Brasil. Decomposição das variações dos saldos em conta 109 corrente, entre cada ano no período 1974/78 e o ano-base de 1973. Base de preços 1986-88.

Tabela 24. Brasil. Decomposição das variações dos saldos em conta 110 corrente, entre cada ano no período 1979/83 e o ano-base de 1978. Base de preços 1986-88.

Tabela 25. Brasil. Decomposição das variações dos saldos em conta 111 corrente, entre cada ano no período 1984/88 e o ano-base de 1983. Base de preços 1986-88.

Tabela 26. Brasil, 1970-1989. Índices de taxas de câmbio efetivas reais (e) para a moeda nacional $(1971=100,0)$.

Tabela 27. Brasil: decomposição dos aumentos dos deficits em conta 113 corrente entre cada ano no período 1974/78 e o ano-base de 1973 (todas as variáveis são proporções do PIB potencial).

Tabela 28. Brasil: decomposição dos aumentos dos deficits em conta 114 corrente entre cada ano no período 1979/83 e o ano-base de 1978 (todas as variáveis são proporções do PIB potencial). 


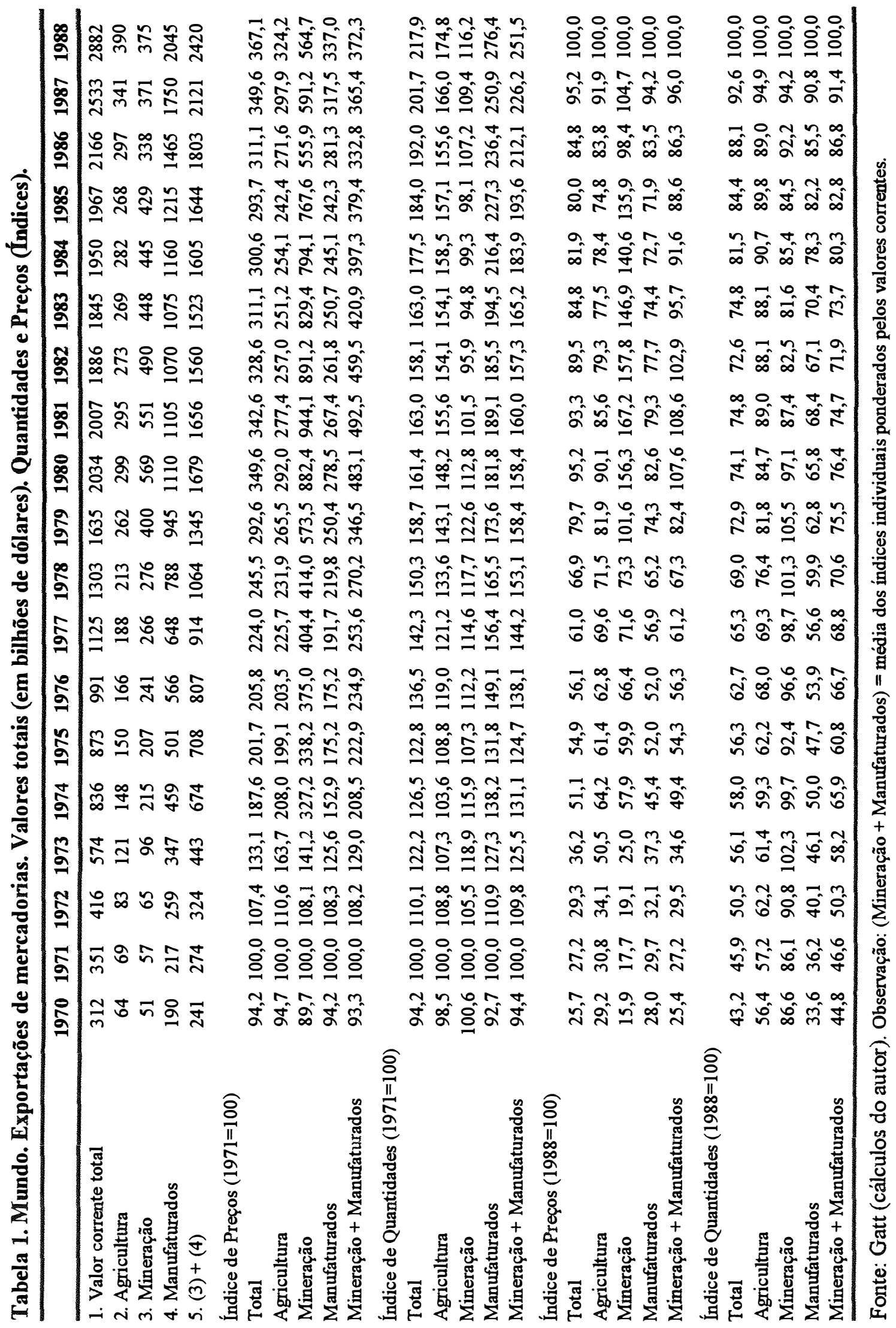


Tabela 2. Brasil. Contas Nacionais, 1971-1988.

\begin{tabular}{|c|c|c|c|c|c|c|c|c|c|}
\hline \multirow[b]{2}{*}{ Ano } & \multicolumn{2}{|c|}{ Cruzeiros correntes } & \multirow[b]{2}{*}{$\begin{array}{c}\text { PIB } \\
\text { Agricultara }\end{array}$} & \multirow{2}{*}{$\begin{array}{c}\text { PNB } \\
\text { Não-agri- } \\
\text { cultura } \\
\end{array}$} & \multicolumn{2}{|c|}{ Dólares correntes } & \multirow{2}{*}{$\begin{array}{c}\text { PIB } \\
\text { Agricalture }\end{array}$} & \multirow[b]{2}{*}{$\begin{array}{c}\text { PNB } \\
\text { Não-agri } \\
\text { cultura } \\
\end{array}$} & \multirow[b]{2}{*}{$\begin{array}{c}\text { Deflator } \\
\text { Implicito } \\
(1980=100,00)\end{array}$} \\
\hline & PIB & $\begin{array}{c}\text { PNB } \\
\left(Y^{\prime}\right)\end{array}$ & & & PIB & PNB & & & \\
\hline 1971 & 258296 & 255837 & 28698 & 227139 & 48846 & 48381 & 5427 & 42954 & 4,28 \\
\hline 1972 & 346581 & 343270 & 38616 & 304654 & 58406 & 57848 & 6508 & 51340 & 5,13 \\
\hline 1973 & 511834 & 507365 & 55855 & 451510 & 83551 & 82822 & 9118 & 73704 & 6,65 \\
\hline 1974 & 745136 & 738953 & 79461 & 659492 & 109740 & 108830 & 11703 & 97127 & 8,95 \\
\hline 1975 & 1049518 & 1035225 & 107349 & 927876 & 129140 & 127381 & 13209 & 114172 & 11,99 \\
\hline 1976 & 1633963 & 1609136 & 168463 & 1440673 & 153093 & 150767 & 15784 & 134983 & 16,93 \\
\hline 1977 & 2492978 & 2452761 & 299525 & 2153236 & 176257 & 173414 & 21177 & 152237 & 24,61 \\
\hline 1978 & 3617246 & 3533411 & 358141 & 3175270 & 200091 & 195454 & 19811 & 175643 & 34,02 \\
\hline 1979 & 5961236 & 5798532 & 576325 & 5222207 & 222285 & 216218 & 21490 & 194728 & 52,51 \\
\hline 1980 & 12399841 & 11995556 & 1232100 & 10763456 & 234797 & 227141 & 23330 & 203811 & 100,00 \\
\hline 1981 & 24654 & 23639 & 2320 & 21319 & 264106 & 253232 & 24853 & 228380 & 208,00 \\
\hline 1982 & 51025 & 48434 & 3930 & 44504 & 282537 & 268190 & 21761 & 246428 & 427,00 \\
\hline 1983 & 118927 & 112087 & 10906 & 101181 & 204976 & 193187 & 18797 & 174390 & 1031,00 \\
\hline 1984 & 393647 & 371706 & 37384 & 334322 & 213636 & 201728 & 20289 & 181440 & 3250,00 \\
\hline 1985 & 1413312 & 1339652 & 130740 & 1208912 & 227137 & 215299 & 21012 & 194287 & 10780,00 \\
\hline 1986 & 3708949 & 3545560 & 328311 & 3217249 & 271618 & 259653 & 24043 & 235610 & 26307,00 \\
\hline 1987 & 11899911 & 11463742 & 950003 & 10513739 & 301088 & 290052 & 24037 & 266016 & 81448,00 \\
\hline 1988 & 91952490 & 88533254 & 7296786 & 81236468 & 346243 & 333368 & 27476 & 305892 & 629243,00 \\
\hline
\end{tabular}

\begin{tabular}{|c|c|c|c|c|c|c|c|c|}
\hline \multirow[b]{2}{*}{ Ano } & \multicolumn{4}{|c|}{ Moeda nacional constante (1971) } & \multicolumn{4}{|c|}{ Moeda nacional constante (1988) } \\
\hline & PIB & $\begin{array}{c}\text { PNB } \\
\left(U^{\prime}\right)\end{array}$ & $\begin{array}{c}\text { PIB } \\
\text { Agricultura }\end{array}$ & $\begin{array}{c}\text { PNB } \\
\text { Não- } \\
\text {-agricultura }\end{array}$ & PIB & $\begin{array}{l}\text { PNB } \\
\left(U^{\prime}\right)\end{array}$ & $\begin{array}{c}\text { PIB } \\
\text { Agricultura }\end{array}$ & $\begin{array}{c}\text { PNB } \\
\text { Não- } \\
\text {-agricultura }\end{array}$ \\
\hline 1971 & 258296 & 255837 & 28698 & 227139 & 37975 & 37613 & 4219 & 33394 \\
\hline 1972 & 289155 & 286393 & 32218 & 254175 & 42511 & 42105 & 4737 & 37369 \\
\hline 1973 & 329421 & 326545 & 35949 & 290596 & 48431 & 48008 & 5285 & 42723 \\
\hline 1974 & 356333 & 353376 & 37999 & 315377 & 52388 & 51953 & 5587 & 46367 \\
\hline 1975 & 374640 & 369538 & 38320 & 331218 & 55079 & 54329 & 5634 & 48696 \\
\hline 1976 & 413075 & 406799 & 42588 & 364210 & 60730 & 59807 & 6261 & 53546 \\
\hline 1977 & 433561 & 426567 & 52091 & 374476 & 63742 & 62714 & 7658 & 55055 \\
\hline 1978 & 455080 & 444533 & 45057 & 399475 & 66906 & 65355 & 6624 & 58731 \\
\hline 1979 & 485890 & 472628 & 46975 & 425653 & 71435 & 69486 & 6906 & 62579 \\
\hline 1980 & 530713 & 513410 & 52734 & 460676 & 78025 & 75481 & 7753 & 67728 \\
\hline 1981 & 507303 & 486418 & 47738 & 438679 & 74583 & 71513 & 7018 & 64494 \\
\hline 1982 & 511445 & 485474 & 39392 & 446082 & 75192 & 71374 & 5791 & 65583 \\
\hline 1983 & 493703 & 465308 & 45274 & 420034 & 72584 & 68409 & 6656 & 61753 \\
\hline 1984 & 518403 & 489508 & 49232 & 440276 & 76215 & 71967 & 7238 & 64729 \\
\hline 1985 & 561129 & 531884 & 51908 & 479976 & 82497 & 78197 & 7631 & 70566 \\
\hline 1986 & 603425 & 576843 & 53414 & 523428 & 88715 & 84807 & 7853 & 76954 \\
\hline 1987 & 625327 & 602407 & 49922 & 552485 & 91935 & 88565 & 7339 & 81226 \\
\hline 1988 & 625445 & 602188 & 49631 & 552556 & 91952 & 88533 & 7297 & 81236 \\
\hline
\end{tabular}

Fonte: IBGE (cálculos do autor).

Observação: Adota-se aqui o seguinte valor: PNB Não-agricultura = PNB - PIB Agricultura 





Tabela 4. Brasil. Comércio exterior, 1971 a 1988. Valores em US\$1000 (FOB).

\begin{tabular}{|c|c|c|c|c|c|c|c|}
\hline \multirow[b]{3}{*}{ Ano } & \multirow[b]{3}{*}{ Total } & \multirow{2}{*}{\multicolumn{2}{|c|}{ Valores correntes }} & \multicolumn{4}{|c|}{ Valores constantes } \\
\hline & & & & \multicolumn{2}{|c|}{ Base 1971/73 } & \multicolumn{2}{|c|}{ Base 1986/88 } \\
\hline & & Agrícola & Não-agrícola & Agrícola & Não-agrícola & Agrícola & Não-agrícola \\
\hline $\begin{array}{l}\text { Exportação } \\
\text { (base) }\end{array}$ & & & & 2943551 & 1387118 & 9899100 & 17169479 \\
\hline 1971 & 2903856 & 1908376 & 1025080 & 2418282 & 1175826 & 5594124 & 2647766 \\
\hline 1972 & 3991219 & 2858012 & 1255373 & 3113829 & 1270616 & 6640177 & 2887621 \\
\hline 1973 & 6199200 & 4331571 & 1880128 & 3298543 & 1714912 & 6898126 & 3899721 \\
\hline 1974 & 7950996 & 4873430 & 2371231 & 2844038 & 2128788 & 5702254 & 4683109 \\
\hline 1975 & 8669944 & 4796961 & 3676137 & 3242371 & 2492651 & 6423688 & 5551882 \\
\hline 1976 & 10128303 & 6072631 & 3628811 & 3557875 & 2214672 & 6845754 & 4899256 \\
\hline 1977 & 12120175 & 7499520 & 4283108 & 3493569 & 2394551 & 6242625 & 5270445 \\
\hline 1978 & 12658944 & 6828116 & 5381319 & 3396266 & 3003779 & 6563145 & 6663551 \\
\hline 1979 & 15244377 & 7715943 & 7043279 & 3400378 & 3692201 & 6786251 & 7749947 \\
\hline 1980 & 20132401 & 10221748 & 9331495 & 4395829 & 5029711 & 8534775 & 9000545 \\
\hline 1981 & 23293035 & 10437532 & 12158518 & 5380337 & 6737229 & 10055004 & 11942306 \\
\hline 1982 & 20175071 & 8677060 & 11067032 & 4958555 & 5810694 & 9465945 & 10996508 \\
\hline 1983 & 21899314 & 9769597 & 12515900 & 5600660 & 7247468 & 10655552 & 13811195 \\
\hline 1984 & 27005336 & 11505278 & 15749386 & 5813064 & 9800325 & 11295545 & 19312086 \\
\hline 1985 & 25639011 & 10152075 & 15874380 & 6068943 & 9576737 & 11427388 & 19594401 \\
\hline 1986 & 22348603 & 8327230 & 13640909 & 4463838 & 6883656 & 8410626 & 14742194 \\
\hline 1987 & 26225115 & 9472944 & 16282876 & 5546458 & 7258076 & 10547091 & 16444963 \\
\hline 1988 & 33786532 & 11180843 & 21902968 & 5519299 & 9828823 & 10706831 & 20321281 \\
\hline $\begin{array}{l}\text { Importação } \\
\text { (base) }\end{array}$ & & & & 40 & 8 & 14 & 12393544 \\
\hline 1971 & 3247393 & 497703 & 2879400 & 605447 & 3305356 & 1576202 & 12739360 \\
\hline 1972 & 4232348 & 665434 & 3728289 & 722985 & 4036985 & 1996562 & 15758336 \\
\hline 1973 & 6192238 & 1108822 & 5275873 & 908429 & 4542153 & 2515553 & 17718157 \\
\hline 1974 & 12641320 & 2016253 & 10958527 & 1065697 & 6264623 & 2883142 & 23703436 \\
\hline 1975 & 12210340 & 1734358 & 10814088 & 890948 & 5609456 & 2430040 & 21482844 \\
\hline 1976 & 12382982 & 1812110 & 10792373 & 1056433 & 5012560 & 2693444 & 19690963 \\
\hline 1977 & 12023412 & 1700602 & 10506805 & 955070 & 4864202 & 2381973 & 17683403 \\
\hline 1978 & 13683146 & 2329644 & 11599363 & 1355307 & 5803166 & 2827547 & 17464657 \\
\hline 1979 & 18083861 & 3309067 & 15158608 & 1663721 & 5724229 & 3102736 & 18337707 \\
\hline 1980 & 22955169 & 3881039 & 19498358 & 1701430 & 5016096 & 2949590 & 17660926 \\
\hline 1981 & 22090580 & 3182396 & 19396874 & 1543733 & 4545167 & 2362243 & 14885426 \\
\hline 1982 & 19394998 & 2718050 & 17177971 & 1547703 & 3744306 & 2089540 & 12829340 \\
\hline 1983 & 15428925 & 2069247 & 13559835 & 844434 & 3510248 & 1564711 & 9495490 \\
\hline 1984 & 13915821 & 2212233 & 12005507 & 1086684 & 4305945 & 1897913 & 9284286 \\
\hline 1985 & 13153491 & 1990637 & 11452352 & 1084699 & 4380254 & 1753579 & 9656220 \\
\hline 1986 & 14044304 & 3067834 & 11338376 & 2279127 & 5736029 & 3271639 & 12453273 \\
\hline 1987 & 15050827 & 2174464 & 13164975 & 1545273 & 4701616 & 2377595 & 12734087 \\
\hline 1988 & 14607853 & 1704795 & 11977124 & 934295 & 3774031 & 1581727 & 11993274 \\
\hline
\end{tabular}

Fonte: CACEX, BACEN e CIEF (diversos anos) 
Tabela 5. Brasil. Exportações. Agricultura. 1971-1979. Valores correntes, em US\$1000 (FOB)

\begin{tabular}{|c|c|c|c|c|c|c|c|c|c|}
\hline Anos & 1971 & 1972 & 1973 & 1974 & 1975 & 1976 & 1977 & 1978 & 1979 \\
\hline Total & 1908376 & 2858012 & 4331571 & 4873430 & 4796961 & 6072631 & 7499520 & 6828116 & 7715943 \\
\hline Soja & 108086 & 294931 & 949348 & 891213 & 1304283 & 1779966 & 2142672 & 1514705 & 1650344 \\
\hline Farelo & 81532 & 152348 & 422635 & 303044 & 465794 & 795004 & 1150152 & 1049908 & 1136933 \\
\hline Grãos & 24309 & 127927 & 494153 & 586271 & 684901 & 788538 & 709606 & 169886 & 179506 \\
\hline Óleo bruto & 27 & 160 & 23807 & 1889 & 152441 & 174642 & 274216 & 283156 & 326798 \\
\hline Óleo refinado & 2218 & 14496 & 8753 & 9 & 1147 & 21782 & 8698 & 11755 & 7107 \\
\hline Café & 822213 & 1057164 & 1344238 & 980298 & 934303 & 2398226 & 2624945 & 2294712 & 2326176 \\
\hline Grãos & 772479 & 989219 & 1244272 & 864313 & 854513 & 2172687 & 2298942 & 1946509 & 1917618 \\
\hline Industrializado & 49734 & 67945 & 99966 & 115985 & 79790 & 225539 & 326003 & 348203 & 408558 \\
\hline Madeira & 111705 & 119567 & 176810 & 195383 & 149626 & 132785 & 137387 & 209910 & 403615 \\
\hline Serrada & 82124 & 72568 & 89952 & 85689 & 77478 & 51336 & 55183 & 45262 & 53236 \\
\hline Pasta química & 4628 & 13296 & 23580 & 36756 & 30572 & 26659 & 18791 & 56628 & 179455 \\
\hline Entalh./Ematelhada & 2115 & 3218 & 20899 & 41076 & 9280 & 19082 & 23651 & 58978 & 104083 \\
\hline Compensada/Contra & 4273 & 5596 & 8971 & 8728 & 7826 & 11214 & 15116 & 24360 & 38285 \\
\hline Laminada & 18565 & 24889 & 33408 & 23134 & 24470 & 24494 & 24646 & 24682 & 28556 \\
\hline Laranja & 39946 & 46240 & 67700 & 64979 & 93980 & 106223 & 182362 & 339593 & 356348 \\
\hline Suco concentrado & 35859 & 41499 & 63622 & 59170 & 82213 & 100900 & 177040 & 332638 & 281452 \\
\hline Farelo de polpa & 0 & 0 & 0 & 0 & 0 & 0 & 0 & 0 & 57417 \\
\hline Frescas - secas & 4087 & 4741 & 4078 & 5809 & 11767 & 5323 & 5322 & 6955 & 17479 \\
\hline Frutas & 11465 & 11733 & 18 & 39 & & 21579 & 22511 & 36929 & 41518 \\
\hline Bananas & 10422 & 9583 & 14870 & 22641 & 30659 & 18084 & 19051 & 23249 & 24464 \\
\hline Sucos & 1043 & 2150 & 3971 & 6098 & 3592 & 3495 & 3460 & 13680 & 17054 \\
\hline Pecuária de corte & 176532 & 282240 & 302404 & 187966 & 167426 & 258838 & 282005 & 259393 & 347209 \\
\hline Fresca e congelada & 98706 & 169205 & 148547 & 29532 & 8530 & 16022 & 39631 & 17155 & 8041 \\
\hline Industrializada & 50948 & 50509 & 69769 & 80979 & 70548 & 113609 & 118826 & 97465 & 126860 \\
\hline Carne eqüina & 12864 & 21847 & 44037 & 39620 & 40197 & 40728 & 30796 & 45473 & 46669 \\
\hline Peles e couros & 14014 & 40679 & 40051 & 37835 & 48151 & 88479 & 92752 & 99300 & 165639 \\
\hline Fumo & 36560 & 46674 & 58458 & 98989 & 141950 & 161197 & 186286 & 238933 & 284329 \\
\hline Cacau & 90905 & 98731 & 142899 & 321567 & 292443 & 309447 & 698330 & 731225 & 876892 \\
\hline $\mathrm{Cru}$ & 61681 & 59158 & 88512 & 210007 & 220369 & 218757 & 435454 & 453813 & 486873 \\
\hline Manteiga & 24335 & 33134 & 47656 & 99991 & 60129 & 70020 & 96823 & 83027 & 119314 \\
\hline Liquor pasta & 4889 & 6439 & 6731 & 11569 & 11945 & 20670 & 166053 & 194385 & 270705 \\
\hline Açúcar & 161870 & 417507 & 595127 & 1402120 & 1132108 & 354564 & 510158 & 386960 & 438466 \\
\hline Demerara & 146554 & 314147 & 454863 & 978300 & 769902 & 152473 & 276510 & 195929 & 247004 \\
\hline Cristal & 6397 & 89401 & 97848 & 283330 & 174342 & 52420 & 55937 & 32764 & 22972 \\
\hline Refinado & 0 & 124 & 5976 & 60302 & 125529 & 101646 & 130238 & 121092 & 93832 \\
\hline Álcool etílico & 311 & 312 & 5393 & 21380 & 16800 & 7035 & 1186 & 3486 & 26013 \\
\hline Melaço de cana & 8608 & 13523 & 31047 & 58808 & 45535 & 40990 & 46287 & 33689 & 48645 \\
\hline
\end{tabular}


Tabela 5. Brasil. Exportações. Agricultura. 1971-1979. Valores correntes, em US\$1000 (FOB)

\begin{tabular}{|c|c|c|c|c|c|c|c|c|c|}
\hline & 1971 & 1972 & 1973 & 1974 & 1975 & 1976 & 1977 & 1978 & 1979 \\
\hline Algodão & 52 & 237289 & 315816 & 216804 & 215412 & 130294 & 230906 & 238382 & 66336 \\
\hline Bruto & 137682 & 188682 & 218068 & 90934 & 97794 & 6957 & 40894 & 52759 & 499 \\
\hline Fios & 6813 & 22782 & 45028 & 66404 & 67835 & 81249 & 120263 & 117093 & 155249 \\
\hline Óleo refinado & 5 & 10 & 99 & 55 & 66 & 1 & 851 & 1170 & 336 \\
\hline Tecidos & 11052 & 25815 & 52621 & 59411 & 49717 & 42087 & 68898 & 67360 & 110252 \\
\hline Seda - fios & 3514 & 6784 & 14473 & 16331 & 20008 & 21528 & 17058 & 19175 & 23701 \\
\hline Amendoim & 47290 & 55639 & 53464 & 68860 & 67962 & 83688 & 67359 & 76493 & 103003 \\
\hline Grão & 8813 & 13651 & 19483 & 28186 & 32228 & 13195 & 19833 & 11610 & 15768 \\
\hline Farelo & 16740 & 14563 & 14521 & 10166 & 3920 & 10785 & 9147 & 8165 & 14599 \\
\hline Óleo bruto & 21737 & 27425 & 19460 & 30508 & 31814 & 59708 & 38379 & 56718 & 72636 \\
\hline Milho - farelo & 3042 & 3396 & 4558 & 5372 & 6607 & 9555 & 13918 & 18425 & 28852 \\
\hline Mamona & 39950 & 55310 & 123336 & 129340 & 54099 & 76929 & 88503 & 112052 & 113306 \\
\hline & 39942 & 53818 & 122807 & 128425 & 51872 & 76625 & 87497 & 110022 & 106600 \\
\hline Óleo refinado & 8 & 1492 & 529 & 915 & 2227 & 304 & 1006 & 2030 & 6706 \\
\hline Carnaúba - cera & 10604 & 11220 & 13311 & 25203 & 14968 & 17509 & 15208 & 18081 & 19617 \\
\hline Castanha & 19124 & 29082 & 32618 & 35245 & 43086 & 39457 & 55834 & 66417 & 81340 \\
\hline Brasil & 14037 & 20229 & 22763 & 20222 & 24735 & 21968 & 32082 & 32710 & 43037 \\
\hline Caju & 5087 & 8853 & 9855 & 15023 & 18351 & 17489 & 23752 & 33707 & 38303 \\
\hline Pimenta - grão & 14943 & 12708 & 16955 & 26125 & 29195 & 32939 & 39476 & 59771 & 47519 \\
\hline Sisal - bruto & 15297 & 22497 & 59445 & 114130 & 30054 & 35967 & 44342 & 32903 & 44771 \\
\hline Palmito - conserva & 4194 & 5049 & 3539 & 10301 & 9073 & 13442 & 16893 & 12702 & 19225 \\
\hline Chá & 9562 & 6422 & 7341 & 10819 & 14702 & 17448 & 22104 & 25622 & 27384 \\
\hline Em $f$ & 3900 & 3187 & 3866 & 3297 & 4747 & 5423 & 8734 & & 9914 \\
\hline Erva-mate & 5662 & 3235 & 3475 & 7522 & 9955 & 12025 & 13370 & 14810 & 17470 \\
\hline Frango & 0 & 0 & 31 & 54 & 3400 & 19564 & 31572 & 46872 & 82054 \\
\hline Pesca & 26022 & 37829 & 30859 & 43592 & 38025 & 51486 & 69691 & 88861 & 133938 \\
\hline Cam & 11110 & 17954 & 8000 & 8621 & 6243 & 11409 & 17485 & 26001 & 55394 \\
\hline Lago & 12836 & 16352 & 18033 & 27858 & 21534 & 26876 & 30563 & 38369 & 53791 \\
\hline Peixe congelado & 2076 & 3523 & 4826 & 7113 & 10248 & 13201 & 21643 & 24491 & 24753 \\
\hline
\end{tabular}

Fonte: CACEX (diversos anos). 
Tabela 6. Brasil. Exportações. Agricultura. 1980-1988. Valores correntes, em US\$1000 (FOB).

\begin{tabular}{|c|c|c|c|c|c|c|c|c|c|}
\hline Anos & 1980 & 1981 & 1982 & 1983 & 1984 & 1985 & 1986 & 1987 & 1988 \\
\hline Total & 8 & 1 & 8 & & 1 & 75 & 30 & 9 & 3 \\
\hline Soja & 7029 & 90850 & 2121638 & 2746 & 44 & 40057 & 7401 & 35 & 45507 \\
\hline Farelo & 1449013 & 2136176 & 1619165 & 1793219 & 1460179 & 1174857 & 1253440 & 19966 & 22917 \\
\hline Grãos & 393930 & 403672 & 123457 & 308571 & 454116 & 762683 & 241897 & 570277 & 728356 \\
\hline Óleo bruto & 411111 & 544871 & 222359 & 155057 & 557178 & 331393 & 71679 & 172341 & 45149 \\
\hline Óleo refinado & 22975 & 106131 & 156657 & 305899 & 94171 & 271124 & 70385 & 131951 & 249085 \\
\hline Café & 2772920 & 1760610 & 2113143 & 2347119 & 75 & 2471 & 7400 & 270 & 869 \\
\hline Grãos & 2486055 & 1516646 & 1857526 & 2095526 & 2564136 & 2369178 & 2005902 & 9196 & 8945 \\
\hline Industrializ & 286865 & 243964 & 255617 & 251593 & 291839 & 263293 & 341498 & 226074 & 212924 \\
\hline Mad & 649689 & 652179 & 491735 & 552730 & 640979 & 494368 & 537023 & 990 & 997618 \\
\hline Serrada & 84590 & & & & & 47007 & 188 & 130 & 129368 \\
\hline Pasta química & 362703 & 363179 & 290951 & 308 & 393347 & 273873 & 319457 & 393510 & 618181 \\
\hline Entalh./Ematelhada & 126864 & 146898 & & & & 74766 & 49464 & 71215 & 72561 \\
\hline Compensada/Contra & 41282 & 48071 & 32342 & 48410 & 63322 & 64429 & 67310 & 70601 & 136651 \\
\hline Lamin & 34250 & & & 34 & 29 & 34293 & 31604 & 534 & 40857 \\
\hline Lara & 96 & 34 & & 65 & 149 & 878 & 296 & 935 & 1243429 \\
\hline Suco concentrado & 338714 & 659343 & 574972 & 607931 & 1414500 & 925 & 678083 & 830502 & 332 \\
\hline Farelo de polpa & 72051 & 77963 & 69720 & 90343 & 64659 & 69329 & 44556 & 75235 & 82389 \\
\hline Fres & & & & & 1 & 24 & 37 & 98 & 16708 \\
\hline Fru & & & & & & & & & \\
\hline Ban & 11164 & 12741 & 10 & & & 16623 & 26 & 03 & 11764 \\
\hline Sucos & 25341 & 64 & 34 & 30 & 6 & 45747 & 18357 & 538 & 886 \\
\hline & & & & & & & & & \\
\hline elada & 299 & 8 & 188 & & & & 749 & & 313 \\
\hline Indu & 232564 & 293 & 250 & 300 & 17 & 35 & 221111 & 11 & 346 \\
\hline Carn & 38772 & 39172 & & 17127 & & 15102 & 7732 & 885 & 4794 \\
\hline Peles e & 101988 & 104 & 113860 & 140716 & 136 & 126499 & 110223 & 397 & 362038 \\
\hline Fumo & 284264 & 356486 & 462777 & 457924 & $44 \varepsilon$ & 437427 & 394520 & 197 & 511173 \\
\hline Cacau & 36 & 581 & 6 & & & 822 & & & 963 \\
\hline $\mathrm{Cru}$ & 291688 & 241582 & 215977 & 73 & 76 & 360614 & 273322 & 87 & 215495 \\
\hline Mant & 158194 & 144900 & 120 & & & 390 & 197742 & 184082 & 171190 \\
\hline Liquor pasta & 219254 & 194923 & 79646 & 118632 & 193500 & 180818 & 130305 & 98960 & 95278 \\
\hline & 1504072 & 1199714 & 663 & & & & 471752 & & 346 \\
\hline Dem & 1500 & & & 69 & 35 & 84 & 141071 & 399 & 166508 \\
\hline Crist & 317398 & 379 & 11 & 25992 & 47692 & 33421 & 50285 & 30583 & 16237 \\
\hline Refinad & & 395926 & 243655 & 167843 & & 168250 & 190041 & 159630 & 162339 \\
\hline Álcool e & 133446 & & 82396 & 79826 & 193045 & 94577 & 69229 & 8398 & 26044 \\
\hline Melaço de cana & 82372 & 68563 & 1127 & 24676 & 22212 & 9287 & 21126 & 26514 & 22218 \\
\hline
\end{tabular}


Tabela 6. Brasil. Exportações. Agricultura. 1980-1988. Valores correntes, em US\$1000 (FOB).

\begin{tabular}{|c|c|c|c|c|c|c|c|c|c|}
\hline Anos & 1980 & 1981 & 1982 & 1983 & 1984 & 1985 & 1986 & 1987 & 1988 \\
\hline Algodão & 306626 & 358661 & 359216 & 561270 & 542375 & 443029 & 295487 & 553442 & 413666 \\
\hline Bruto & 11226 & 41497 & 61769 & 188510 & 41556 & 76754 & 16755 & 160179 & 31297 \\
\hline Fios & 181165 & 183875 & 160142 & 196677 & 234327 & 156295 & 115638 & 213258 & 188989 \\
\hline Óleo refinado & 4528 & 18531 & 41050 & 32914 & 71478 & 71768 & 30935 & 29266 & 44209 \\
\hline Tecidos & 109707 & 114758 & 96255 & 143169 & 195014 & 138212 & 132159 & 150739 & 149171 \\
\hline Seda - fios & 27916 & 28259 & 23019 & 26063 & 30536 & 28192 & 26686 & 27230 & 43345 \\
\hline Amendoim & 122874 & 84686 & 41396 & 34113 & 23943 & 60489 & 13657 & 16007 & 8365 \\
\hline Grão & 21421 & 32438 & 11256 & 8353 & 9499 & 11922 & 7812 & 5571 & 4644 \\
\hline Farelo & 16526 & 9078 & 6122 & 3708 & 1631 & 2670 & 1982 & 737 & \\
\hline Óleo bruto & 84927 & 43170 & 24018 & 22052 & 12813 & 45897 & 3863 & 9699 & 3721 \\
\hline Milho - farelo & 9813 & 353 & 1 & 111 & 21279 & 0 & & 1000 & 650 \\
\hline Mamona & 109689 & 87807 & 45255 & 38749 & 65928 & 57913 & 51819 & 56030 & 54003 \\
\hline Óleo bruto & 89002 & 46627 & 13395 & 2334 & 0 & 554 & 1768 & 0 & 0 \\
\hline Óleo refinado & 20687 & 41180 & 31860 & 36415 & 65928 & 57359 & 50051 & 56030 & 54003 \\
\hline Carnaúba - cera & 16983 & 17786 & 14537 & 13081 & 10529 & 12697 & 17544 & 19451 & 23866 \\
\hline Castanha & 95997 & 103229 & 99461 & 105048 & 90430 & 128590 & 130028 & 116925 & 137362 \\
\hline Brasil & 26821 & 24734 & 32240 & 36038 & 24330 & 25155 & 21871 & 29134 & 25943 \\
\hline Caju & 69176 & 78495 & 67221 & 69010 & 66100 & 103435 & 108157 & 87791 & 111419 \\
\hline Pimenta - grão & 54722 & 58507 & 50416 & 34740 & 73673 & 78381 & 92350 & 123508 & 60120 \\
\hline Sisal - bruto & 58049 & 34289 & 15914 & 33722 & 29519 & 26797 & 23509 & 21157 & 28589 \\
\hline Palmito - conserva & 34633 & 23652 & 19996 & 27020 & 25685 & 10220 & 23532 & 35539 & 30080 \\
\hline Chá & 48628 & 39074 & 15583 & 17764 & 15737 & 14109 & 17056 & 19604 & 34631 \\
\hline Em folhas & 11206 & 10778 & 542 & 131 & 88 & 22 & 49 & 42 & 36 \\
\hline Erva-mate & 37422 & 28296 & 15041 & 17633 & 15649 & 14087 & 17007 & 19562 & 34595 \\
\hline Frango & 206690 & 354291 & 285563 & 242212 & 263538 & 242872 & 224333 & 215909 & 235028 \\
\hline Pesca & 118294 & 143981 & 152594 & 128697 & 165316 & 163955 & 146470 & 171163 & 174092 \\
\hline Camarão & 44957 & 51644 & 72264 & 68468 & 91773 & 98868 & 89843 & 83771 & 91783 \\
\hline Lagosta & 37575 & 49993 & 49221 & 29011 & 51539 & 38964 & 28036 & 58904 & 54802 \\
\hline Peixe congelado & 35762 & 42344 & 31109 & 31218 & 22004 & 26123 & 28591 & 28488 & 27507 \\
\hline
\end{tabular}

Fonte: CACEX (diversos anos). 
Tabela 7. Brasil. Exportações. Agricultura. 1971-79. Quantidades (em toneladas).

\begin{tabular}{|c|c|c|c|c|c|c|c|c|c|}
\hline 8 & 1971 & 1972 & 1973 & 1974 & 1975 & 1976 & 1977 & 1978 & 1979 \\
\hline Total & 81082 & 9321723 & 1079558 & 1100039 & 17 & 8018 &  & & 13119781 \\
\hline Soja & 94 & & & 657 & 6731392 & 9 & & & \\
\hline & 911407 & 1405329 & 581493 & 2030942 & 3133581 & & & & 0806 \\
\hline Grãos & 213426 & 1028273 & 1786139 & 2730426 & 3333334 & 3639497 & 2556866 & 58527 & 638767 \\
\hline Óleo bruto & 72 & 600 & 61407 & 2277 & 263183 & 452889 & 487225 & & 524558 \\
\hline Óleo refinado & 6589 & 59443 & 29452 & 12 & 1294 & 45766 & 14938 & 15778 & 9206 \\
\hline Café & 1057517 & 1084510 & 13 & 720907 & 3368 & 848869 & 544156 & & 5149 \\
\hline Grãos & 34266 & 1050256 & 1071377 & 683784 & 81990 & 805267 & & & 2196 \\
\hline Industrializado & 23251 & 34254 & & 37123 & 31378 & 43602 & & & 52953 \\
\hline Mad & 881 & 08 & 31 & 7 & 8 & 503416 & & & 2947 \\
\hline Serrada & 700250 & 588781 & 569581 & 356217 & 295185 & 241368 & 47 & & 36370 \\
\hline Pasta química & 33349 & 140697 & & & 153392 & 140 & & & 5222 \\
\hline Entalh. $/$ & 12956 & 19512 & 73072 & 110484 & 25197 & 55335 & 72334 & & 351526 \\
\hline /Con & 18562 & 208 & & & 20472 & & & & 71782 \\
\hline Laminada & 32764 & 38915 & 35064 & 290 & 31312 & $37 C$ & 36968 & 35 & 27047 \\
\hline Laranja & 141445 & 153790 & 24 & 148 & 253974 & 246 & 44 & 1 & 878962 \\
\hline $\begin{array}{l}\text { Suco concentrado } \\
\text { Farelo de polpa }\end{array}$ & 77334 & 87157 & & & 903 & 209 & & & $\begin{array}{l}292364 \\
496993\end{array}$ \\
\hline Fres & 64111 & 533 & 34 & 35 & 73071 & 36404 & 91 & 45407 & 89605 \\
\hline & & & & & & & & & 145204 \\
\hline Bananas & 176325 & 114189 & 138493 & 156019 & 147445 & 92149 & 111652 & 132 & 128492 \\
\hline Suco & 1804 & 3871 & 6128 & 90 & 7166 & 5856 & 4068 & & 16712 \\
\hline & 5805 & & & & 97128 & 0 & & & 99052 \\
\hline Fre & 88741 & 155627 & & 19] & 5333 & & & & 2659 \\
\hline ada & 34313 & 36144 & 01 & 348 & 42173 & 64 & 79 & & 45778 \\
\hline & 27175 & 37536 & 51528 & 423 & 39762 & 386 & & & 29046 \\
\hline Pel & 5576 & 11336 & 8366 & 7515 & 9860 & 14736 & & & 21569 \\
\hline Fumo & 60181 & 63258 & 63599 & 91451 & 98158 & 101161 & 101 & 109 & 126325 \\
\hline Cacau & & & & & & & & & \\
\hline Cru & 116072 & 102256 & 774 & 1298 & 176628 & 128 & & & 156932 \\
\hline & 21131 & & 24234 & 28771 & 21574 & 21676 & & & 21167 \\
\hline Liquor pasta & 19638 & 25006 & 25300 & 23946 & 22901 & 23384 & 36973 & 47806 & 67562 \\
\hline & & & & & & & & & 592374 \\
\hline & 190563 & 2054454 & 235 & & 1235119 & & & & 1282872 \\
\hline Cri & 70660 & 480456 & 450353 & 487096 & 279469 & 205834 & 481 & 183400 & 110783 \\
\hline & 0 & 610 & 22027 & 102243 & 216186 & 360746 & 624954 & 614400 & 435573 \\
\hline & & & & & 51900 & & & & 92591 \\
\hline Melaço de cana & 454308 & 587437 & 799349 & 1004456 & 881499 & 843643 & 1041048 & 775099 & 670555 \\
\hline
\end{tabular}


Tabela 7. Brasil. Exportações. Agricultura. 1971-79. Quantidades (em toneladas). (Cont.)

\begin{tabular}{|c|c|c|c|c|c|c|c|c|c|}
\hline Anos & 1971 & 1972 & 1973 & 1974 & 1975 & 1976 & 1977 & 1978 & 1979 \\
\hline Algodão & 242242 & 321818 & 337782 & 131365 & 170172 & 59140 & 109702 & 120260 & 82052 \\
\hline Bruto & 226809 & 284201 & 282867 & 83160 & 107202 & 5579 & 34732 & 44515 & 308 \\
\hline Fios & 6541 & 19237 & 29388 & 28326 & 41933 & 40964 & 52644 & 52931 & 55499 \\
\hline Óleo refinado & 10 & 19 & 260 & 73 & 87 & 1 & 1179 & 1905 & 480 \\
\hline Tecidos & 8882 & 18361 & 25267 & 19806 & 20950 & 12596 & 21147 & 20909 & 25765 \\
\hline Seda - fios & 214 & 375 & 477 & 627 & 1004 & 999 & 852 & 798 & 721 \\
\hline Amendoim & 294312 & 303076 & 178996 & 159408 & 132063 & 206038 & 126273 & 129955 & 191854 \\
\hline Grão & 35667 & 55924 & 54285 & 52989 & 59167 & 25252 & 30942 & 17331 & 24468 \\
\hline Farelo & 201123 & 169963 & 80380 & 74827 & 35573 & 87964 & 47530 & 52745 & 86121 \\
\hline Óleo bruto & 57522 & 77189 & 44331 & 31592 & 37323 & 92822 & 47801 & 59879 & 81265 \\
\hline Milho - farelo & 51040 & 52282 & 54828 & 58299 & 61558 & 81938 & 112612 & 138552 & 181696 \\
\hline Mamona & 134966 & 130229 & 132223 & 156822 & 94985 & 141399 & 101270 & 143071 & 147226 \\
\hline Óleo bruto & 134946 & 127182 & 131683 & 155793 & 91453 & 140895 & 100268 & 140725 & 140339 \\
\hline Óleo refinado & 20 & 3047 & 540 & 1029 & 3532 & 504 & 1002 & 2346 & 6887 \\
\hline Carnaúba - cera & 12716 & 12572 & 14150 & 8705 & 7320 & 9223 & 8588 & 10246 & 10862 \\
\hline Castanha & 28824 & 44750 & 39846 & 28286 & 45651 & 32558 & 28598 & 32114 & 41004 \\
\hline Brasil & 24538 & 37579 & 33848 & 20664 & 34230 & 23293 & 21292 & 20921 & 29106 \\
\hline Caju & 4286 & 7171 & 5998 & 7622 & 11421 & 9265 & 7306 & 11193 & 11898 \\
\hline Pimenta - grão & 17326 & 14298 & 13761 & 15490 & 17944 & 20240 & 17710 & 29957 & 25186 \\
\hline Sisal - bruto & 147481 & 152124 & 160241 & 139013 & 51956 & 108936 & 119033 & 83260 & 81758 \\
\hline Palmito - conser & 7177 & 7364 & 4416 & 8509 & 7012 & 9793 & 11063 & 5589 & 6832 \\
\hline Chá & 35308 & 21934 & 23476 & 21669 & 25197 & 29973 & 28172 & 32923 & 33761 \\
\hline Em folhas & 5242 & 4072 & 5281 & 3844 & 4390 & 5430 & 5043 & 7773 & 7203 \\
\hline Erva-mate & 30066 & 17862 & 18195 & 17825 & 20807 & 24543 & 23129 & 25150 & 26558 \\
\hline Frango & 0 & 0 & 30 & 46 & 3571 & 19636 & 32829 & 50805 & 81672 \\
\hline Pesca & 11048 & 17125 & 12130 & 12821 & 13853 & 13296 & 22757 & 26027 & 26146 \\
\hline Camarão & 4391 & 6703 & 2622 & 2437 & 1683 & 1785 & 3110 & 4925 & 7172 \\
\hline Lagosta & 2514 & 2630 & 2549 & 3069 & 2499 & 2353 & 2797 & 3181 & 3744 \\
\hline Peixe congelado & 4143 & 7792 & 6959 & 7315 & 9671 & 9158 & 16850 & 17921 & 15230 \\
\hline
\end{tabular}

Fonte: CACEX (diversos anos). 
Tabela 8. Brasil. Exportações. Agricultura. 1980-88. Quantidades (em toneladas).

\begin{tabular}{|c|c|c|c|c|c|c|c|c|c|}
\hline Anos & 1980 & 1981 & 1982 & 1983 & 1984 & 1985 & 1986 & 1987 & 1988 \\
\hline Total & 17561 & 20482730 & 17078973 & 19886615 & 20515971 & 22123929 & 16506444 & 20182790 & 195356 \\
\hline Soja & 8899558 & 11615367 & 9070945 & 10858831 & 10076344 & 13033860 & 8546621 & 11814530 & 11406578 \\
\hline Farelo & 6582225 & 8884369 & 7720762 & 8492849 & 7587025 & 8588020 & 6952164 & 7802299 & 8129258 \\
\hline Grãos & 1548883 & 1449731 & 500804 & 1295095 & 1561110 & 3491476 & 1197741 & 3023651 & 2597364 \\
\hline Óleo bruto & 731852 & 1107622 & 509324 & 354370 & 803028 & 521276 & 219115 & 74228 & 109170 \\
\hline Óleo refinado & 6598 & 173645 & 340055 & 716517 & 125181 & 433088 & 177601 & 14352 & 570786 \\
\hline Café & 2899 & 873558 & 936173 & 36166 & 1081160 & 1081250 & 534753 & 1033968 & 44536 \\
\hline G & & & & & & 611 & 477907 & 987609 & 04357 \\
\hline Industrializado & 41134 & 48115 & 48153 & 46563 & 49309 & 47639 & 56846 & 46359 & 40179 \\
\hline Madeira & 1527183 & 1536646 & 1298854 & 1498019 & 1496294 & 1438361 & 1347538 & 332019 & 765956 \\
\hline Serra & 209633 & 144358 & 131619 & & & & 498 & & 316044 \\
\hline Pasta química & 885776 & 944643 & 867672 & 978293 & 962647 & 912974 & 861509 & 00418 & 1044138 \\
\hline Entalh./Ematelha & 337850 & 342405 & 211560 & 240284 & 259553 & 197379 & 115685 & 124847 & 127864 \\
\hline Compensada/Con & 64030 & 73305 & & & & & 141569 & & 236013 \\
\hline Lamina & 29894 & 31935 & 35 & 2 & 15 & 39032 & 37277 & 007 & 41897 \\
\hline Laranja & 1105227 & 1440366 & 1226886 & 1469915 & 1868830 & 1580224 & 1523916 & 1747196 & 1561692 \\
\hline Suco concentrado & 401143 & 639143 & 522 & & & 484782 & 068 & 75 & 663600 \\
\hline Farelo de polpa & 621845 & 741543 & 634 & 827370 & 860874 & 990146 & 633040 & 35 & 818982 \\
\hline Frescas - secas & 82239 & 59680 & 70059 & 89435 & 103151 & 105296 & 87808 & 81093 & 79110 \\
\hline Frutas & 88972 & 92106 & 85261 & 79466 & 73 & 119875 & 118345 & 101 & 95807 \\
\hline Bananas & 67328 & 66694 & 59178 & 48690 & 48959 & 74924 & 100838 & 20 & 76160 \\
\hline Sucos & 21644 & 25412 & 26083 & 30776 & 39414 & 44951 & 17507 & 20084 & 19647 \\
\hline Pecuár & 115607 & 188365 & 244081 & 311063 & 303378 & 320127 & 219937 & 192057 & 371745 \\
\hline & 5726 & 46399 & 94441 & 120297 & 115096 & 140038 & 79657 & 65556 & 167938 \\
\hline Industrializada & 72266 & 98108 & 102713 & 128863 & 141190 & 129399 & 107800 & 89244 & 130871 \\
\hline Carne eqüina & 24503 & 23417 & 16410 & 13910 & 15368 & 14380 & 7156 & 3570 & 4024 \\
\hline Peles e couros & 13112 & 20441 & 30517 & 47993 & 31724 & 36310 & 25324 & 33687 & 68912 \\
\hline Fumo & 128396 & 131690 & 144926 & 155258 & 160908 & 169544 & 148953 & 147305 & 171255 \\
\hline Cacau & 93 & 5 & 21 & 59 & 39 & 11 & 231091 & 22 & 227378 \\
\hline Cru & 123580 & 125228 & 143 & 152773 & 107186 & 46 & 134692 & 82 & 134490 \\
\hline Manteig & 26751 & 29032 & 30454 & 32096 & 35808 & 42764 & 43362 & 42708 & 46878 \\
\hline Liquor pasta & 68062 & 72505 & 36545 & 52290 & 66845 & 68601 & 53037 & 42178 & 46010 \\
\hline Aç & 4 & 41 & 2974184 & 41 & 66 & 126 & 3047580 & 2676806 & 2214832 \\
\hline Dem & 1391530 & 1563519 & 12 & 13 & 31 & 104 & 29 & 907860 & 891878 \\
\hline Cristal & 569022 & 221689 & 397665 & 145820 & 302788 & 308053 & 330603 & 192703 & 92381 \\
\hline Refinado & 611884 & 915635 & 1089841 & 782642 & 1211590 & 1192104 & 1195959 & 1094827 & 780933 \\
\hline Álcool etílico & 308205 & 133155 & 245734 & 345536 & 722582 & 335662 & 244365 & 29739 & 96375 \\
\hline Melaço de cana & 831033 & 620143 & 18766 & 386230 & 371125 & 200736 & 372924 & 451677 & 353265 \\
\hline
\end{tabular}


Tabela 8. Brasil. Exportações. Agricultura. 1980-88. Quantidades (em toneladas).

\begin{tabular}{|c|c|c|c|c|c|c|c|c|c|}
\hline Anos & 1980 & 1981 & 1982 & 1983 & 1984 & 1985 & 1986 & 1987 & 1988 \\
\hline Algodão & 98419 & 162229 & 228045 & 374451 & 268950 & 308946 & 212490 & 367684 & 230258 \\
\hline Bruto & 8651 & 30266 & 56487 & 180179 & 32273 & 86574 & 36364 & 173940 & 34765 \\
\hline Fios & 57380 & 72204 & 64834 & 82195 & 87649 & 65114 & 48166 & 71832 & 61238 \\
\hline Óleo refinado & 7301 & 29800 & 80352 & 68800 & 92843 & 116998 & 92330 & 82510 & 97593 \\
\hline Tecidos & 25087 & 29959 & 26372 & 43277 & 56185 & 40260 & 35630 & 39402 & 36662 \\
\hline Seda - fíos & 848 & 968 & 815 & 1031 & 1249 & 1231 & 1120 & 1051 & 1228 \\
\hline Amendoim & 253982 & 118813 & 102797 & 95346 & 39977 & 82844 & 43928 & 39071 & 14116 \\
\hline Grão & 32376 & 30365 & 17369 & 12402 & 12842 & 19572 & 11600 & 8192 & 6645 \\
\hline Farelo & 101469 & 46421 & 41454 & 36580 & 13380 & 36841 & 25152 & 8526 & \\
\hline Óleo bruto & 120137 & 42027 & 43974 & 46364 & 13755 & 26431 & 7176 & 22353 & 7471 \\
\hline Milho - farelo & 56796 & 2500 & 1 & 360 & 195212 & & & 10000 & 6500 \\
\hline Mamona & 112966 & 103706 & 54685 & 42516 & 62633 & 95847 & 98747 & 80660 & 59523 \\
\hline Óleo bruto & 92637 & 54492 & 16159 & 2773 & & 870 & 3173 & & \\
\hline Óleo refinado & 20329 & 49214 & 38526 & 39743 & 62633 & 94977 & 95574 & 80660 & 59523 \\
\hline Carnaúba - cera & 9668 & 10089 & 8480 & 10433 & 10006 & 9417 & 10980 & 11656 & 12109 \\
\hline Castanha & 36987 & 34138 & 35361 & 41278 & 34435 & 49903 & 41101 & 35444 & 41504 \\
\hline Brasil & 22436 & 18610 & 18105 & 21962 & 19664 & 24915 & 19631 & 20221 & 18079 \\
\hline Caju & 14551 & 15528 & 17256 & 19316 & 14771 & 24988 & 21470 & 15223 & 23425 \\
\hline Pimenta - grão & 31964 & 46882 & 46172 & 30378 & 37154 & 25312 & 21905 & 26260 & 24393 \\
\hline Sisal - bruto & 97044 & 65693 & 33405 & 90586 & 82440 & 82928 & 67760 & 60095 & 71162 \\
\hline Palmito - conser & 10056 & 8292 & 8766 & 10691 & 9884 & 5136 & 8351 & 9615 & 7773 \\
\hline Chá & 33456 & 32158 & 24056 & 22365 & 20088 & 22264 & 13062 & 17672 & 29379 \\
\hline Em folhas & 7780 & 7830 & 288 & 44 & 26 & 8 & 7 & 14 & 27 \\
\hline Erva-mate & 25676 & 24328 & 23768 & 22321 & 20062 & 22256 & 13055 & 17658 & 29352 \\
\hline Frango & 168713 & 293933 & 301842 & 289301 & 280284 & 277142 & 226709 & 210841 & 236924 \\
\hline Pesca & 32874 & 44325 & 42777 & 46761 & 35567 & 51681 & 41557 & 39188 & 40990 \\
\hline Camarão & 7498 & 8836 & 9156 & 8984 & 12270 & 15971 & 12219 & 10826 & 12954 \\
\hline Lagosta & 2541 & 2759 & 2759 & 1585 & 2842 & 2285 & 1451 & 2926 & 2638 \\
\hline Peixe congelado & 22835 & 32730 & 30862 & 36192 & 20455 & 33425 & 27887 & 25436 & 25398 \\
\hline
\end{tabular}

Fonte: CACEX (diversos anos). 







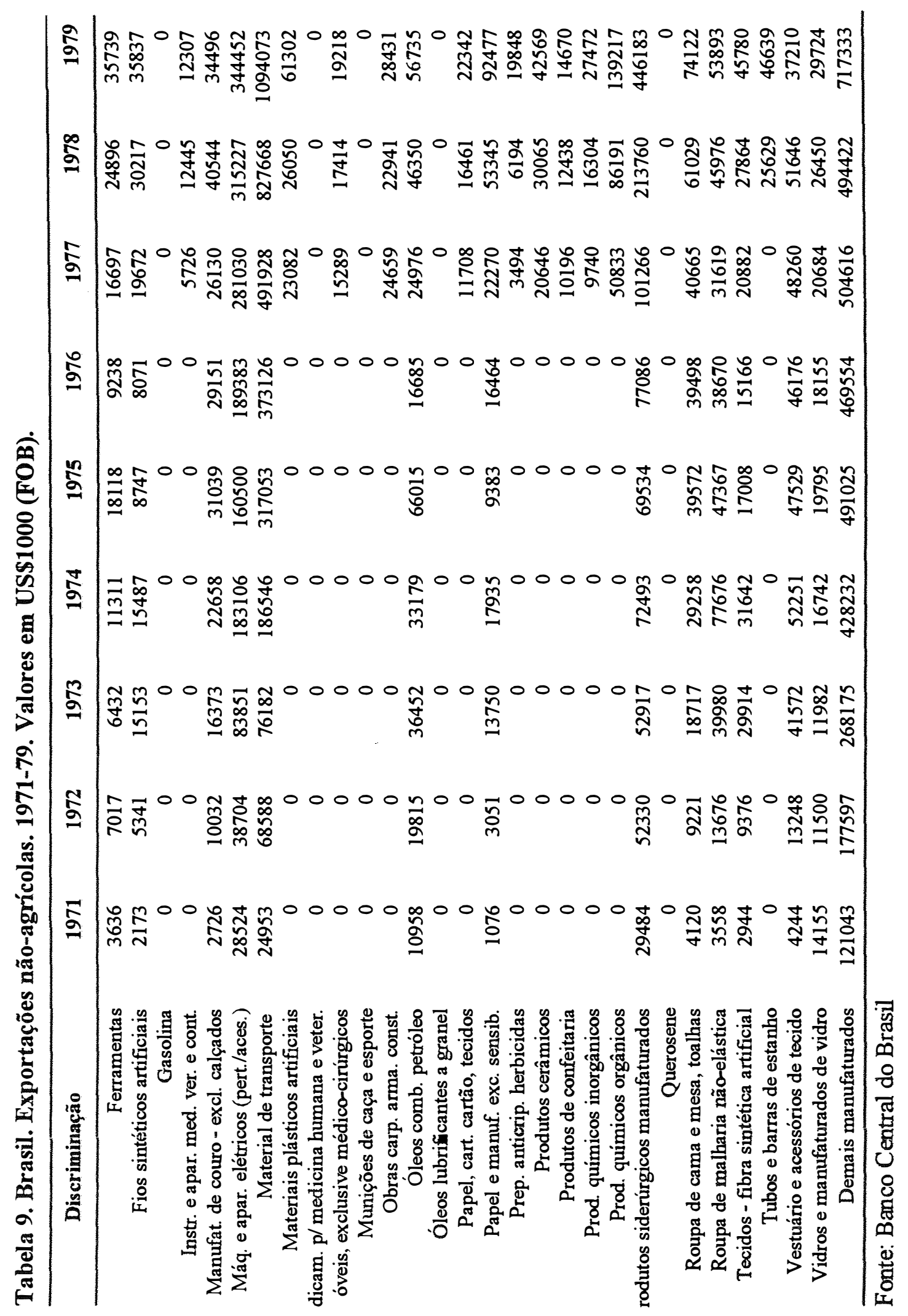




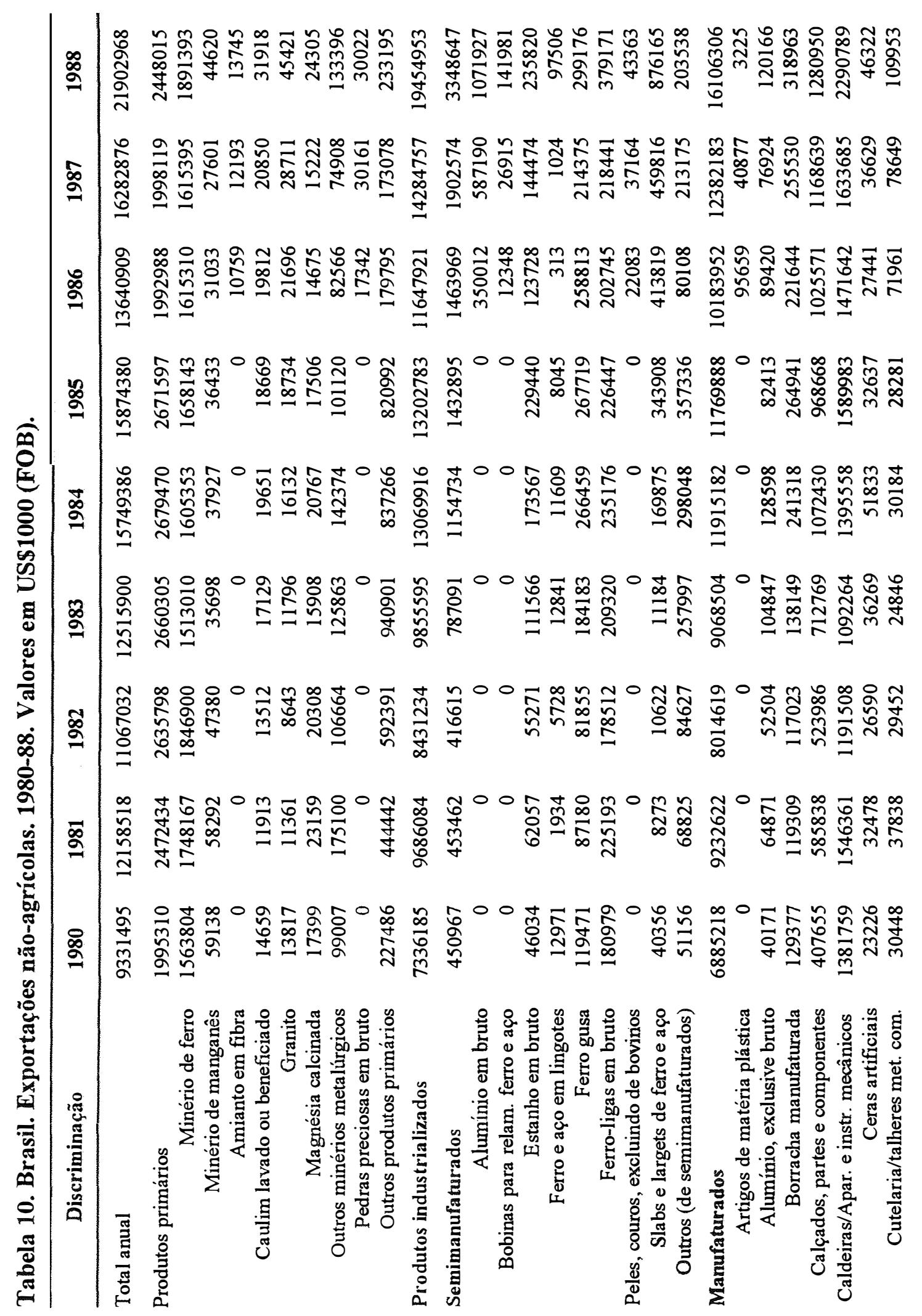




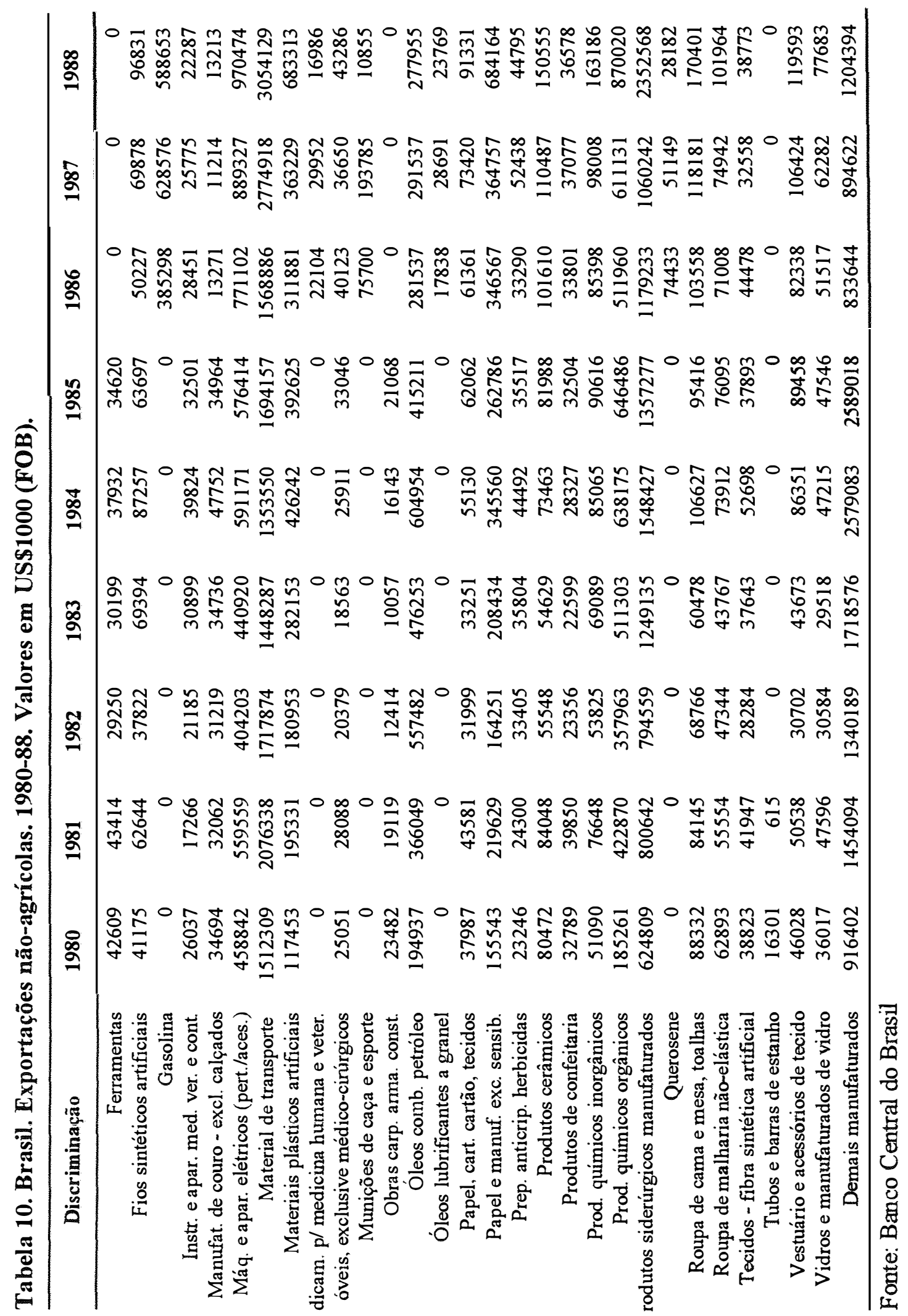









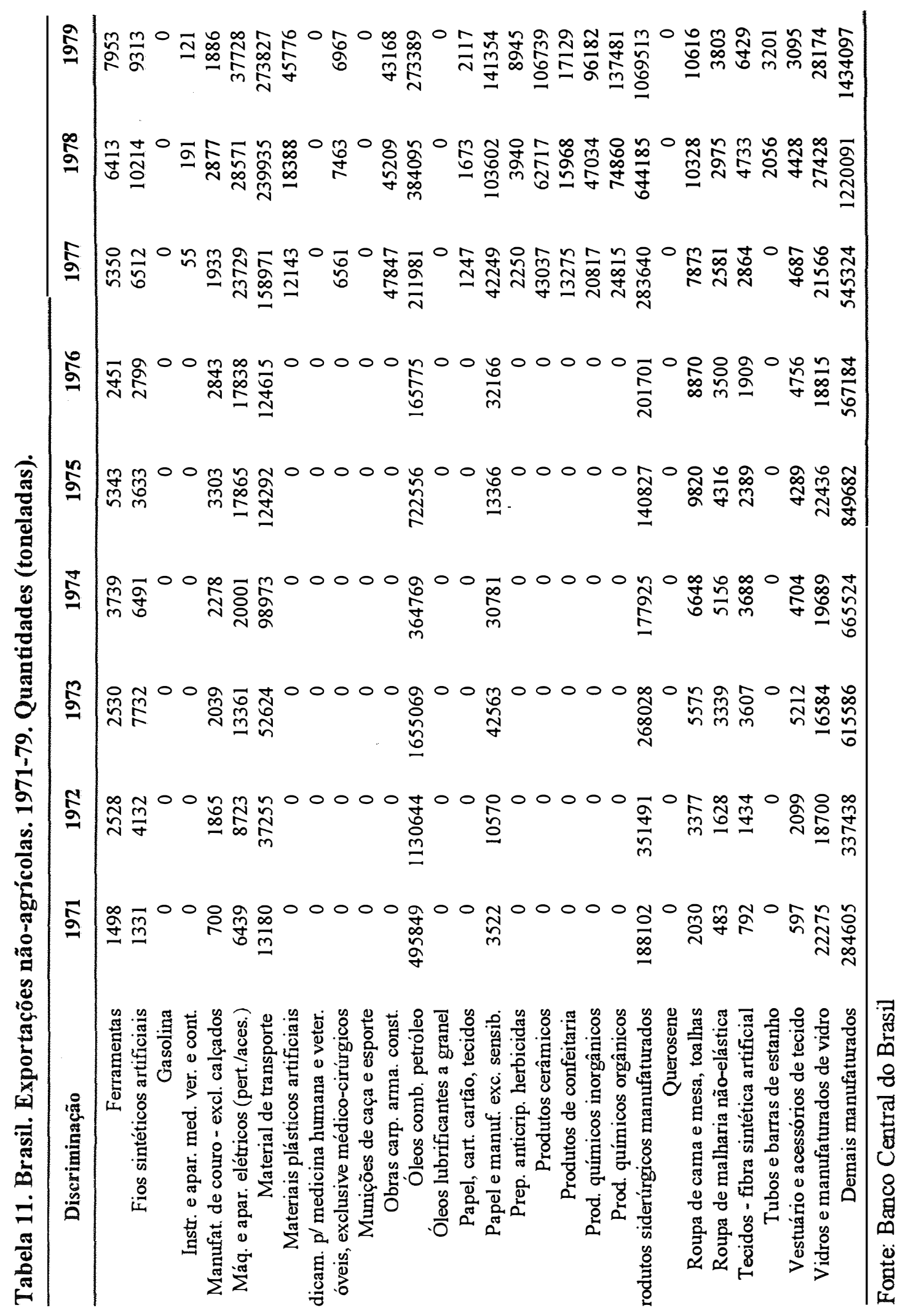









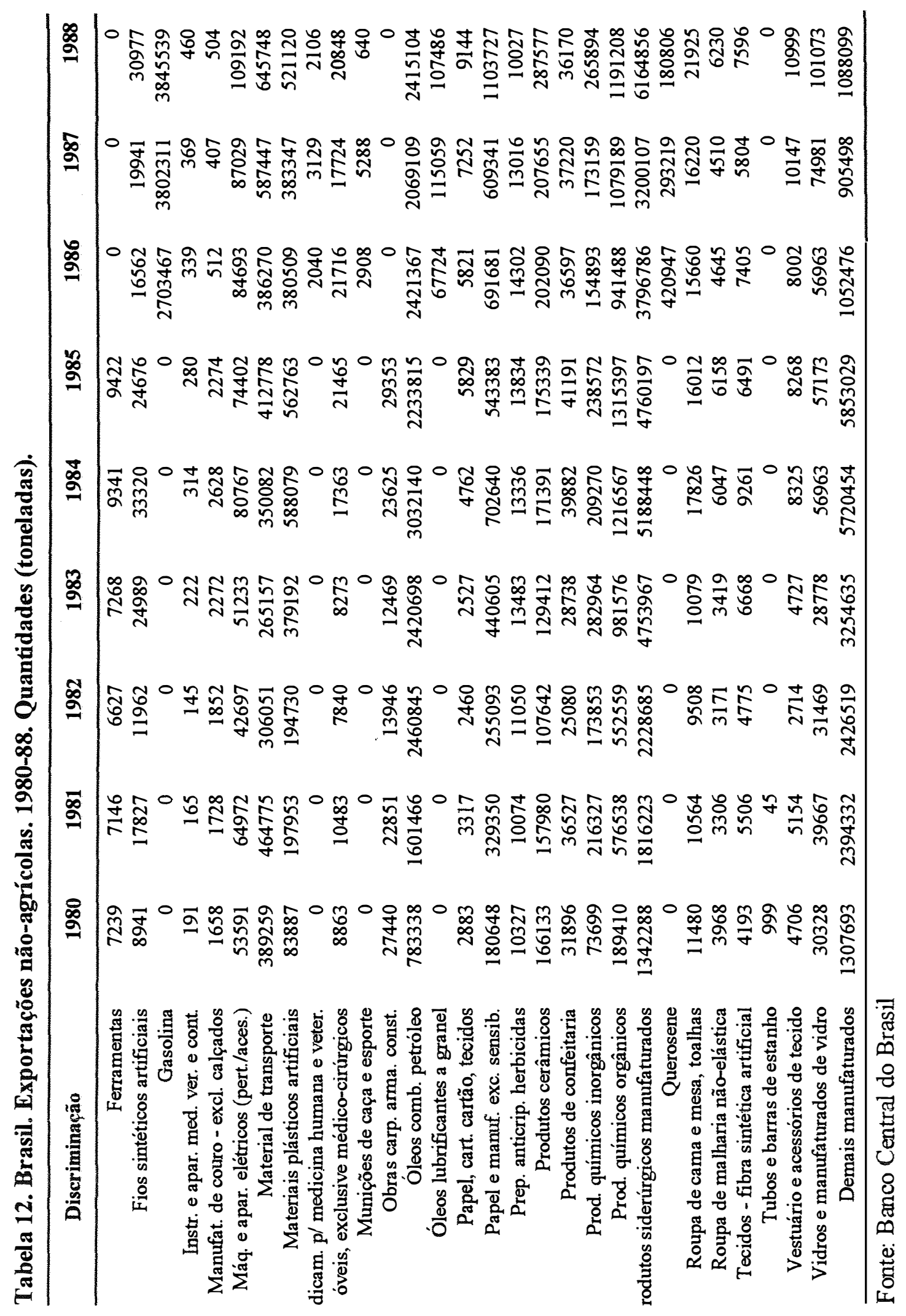




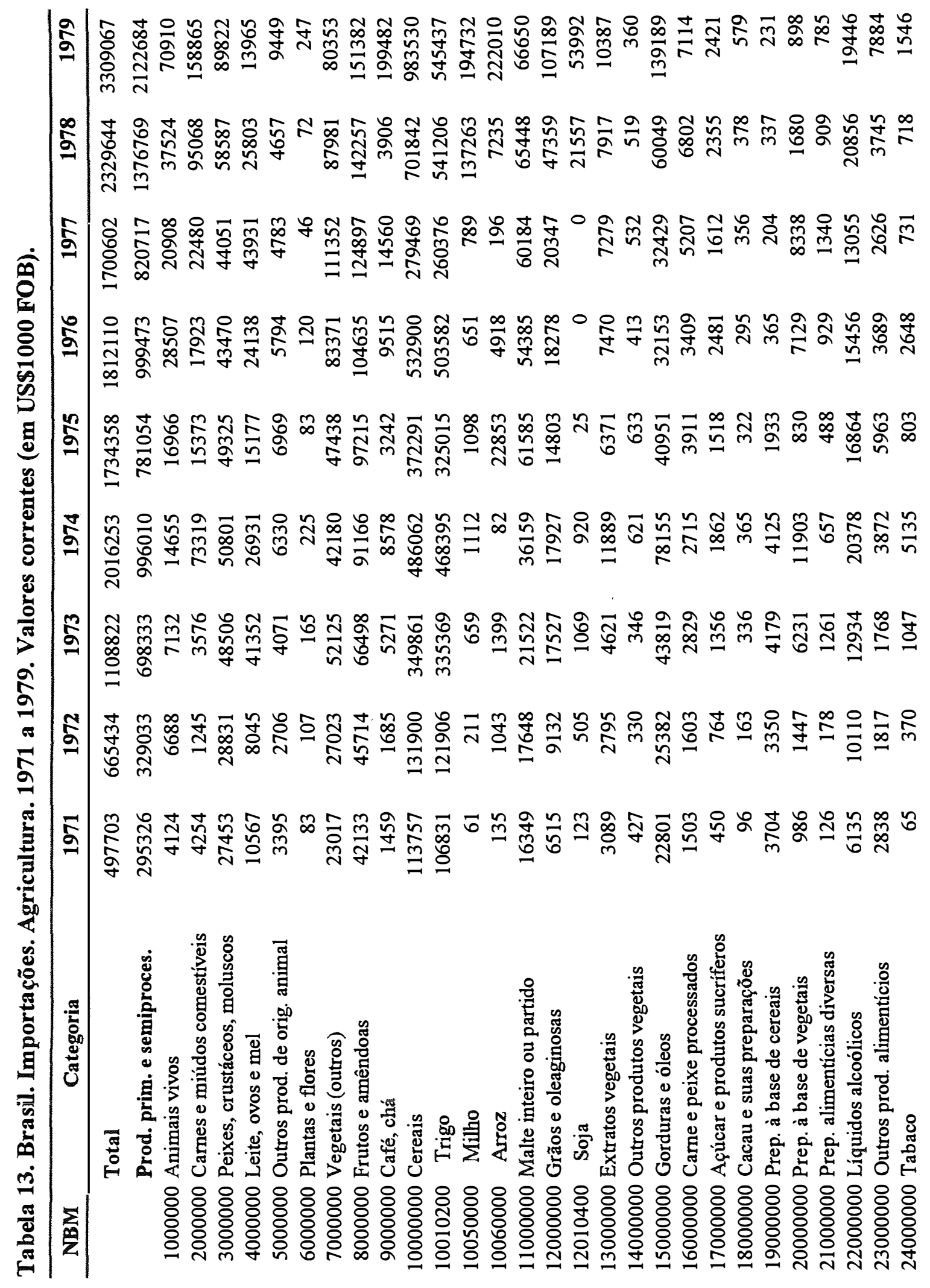














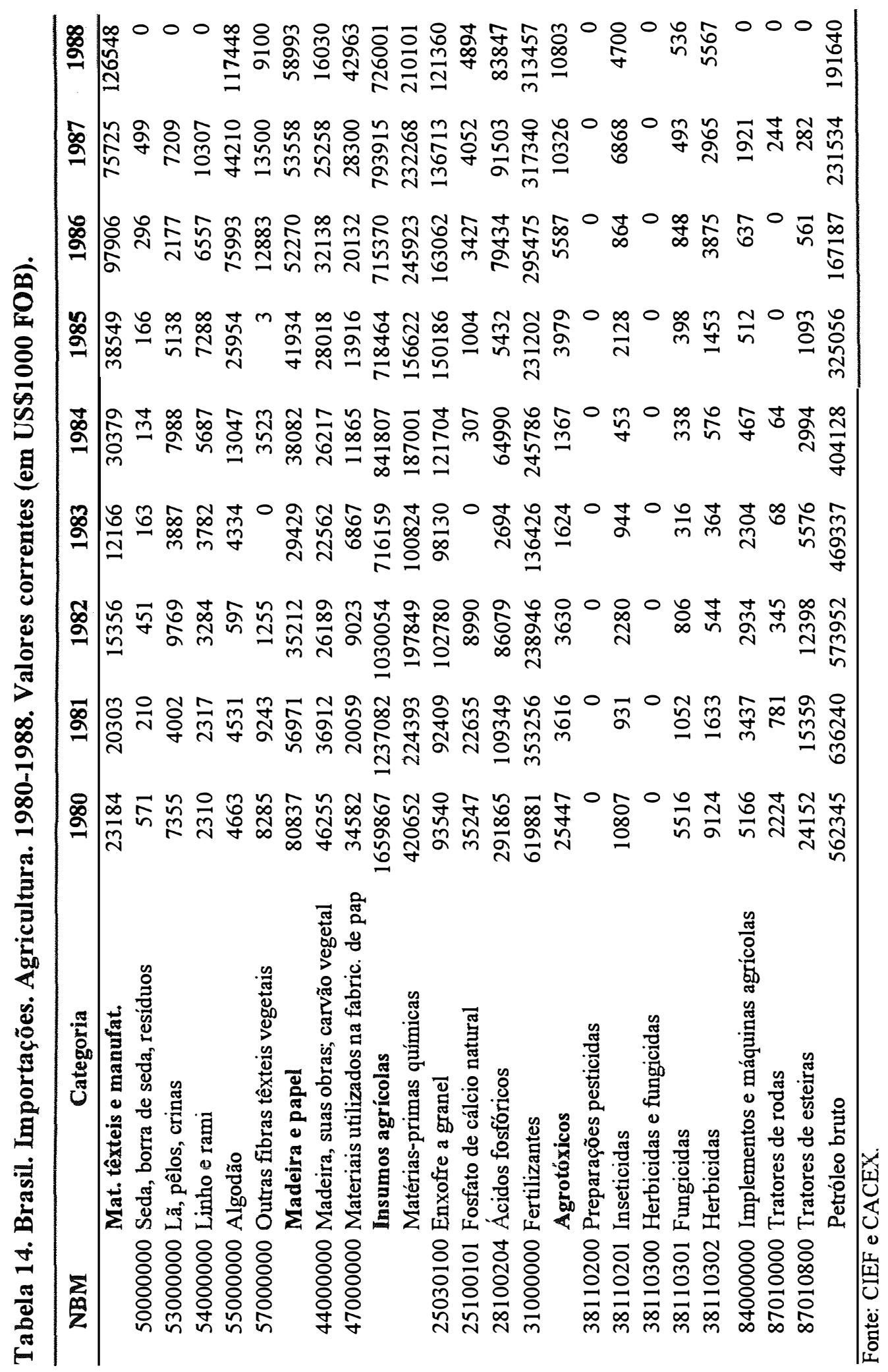




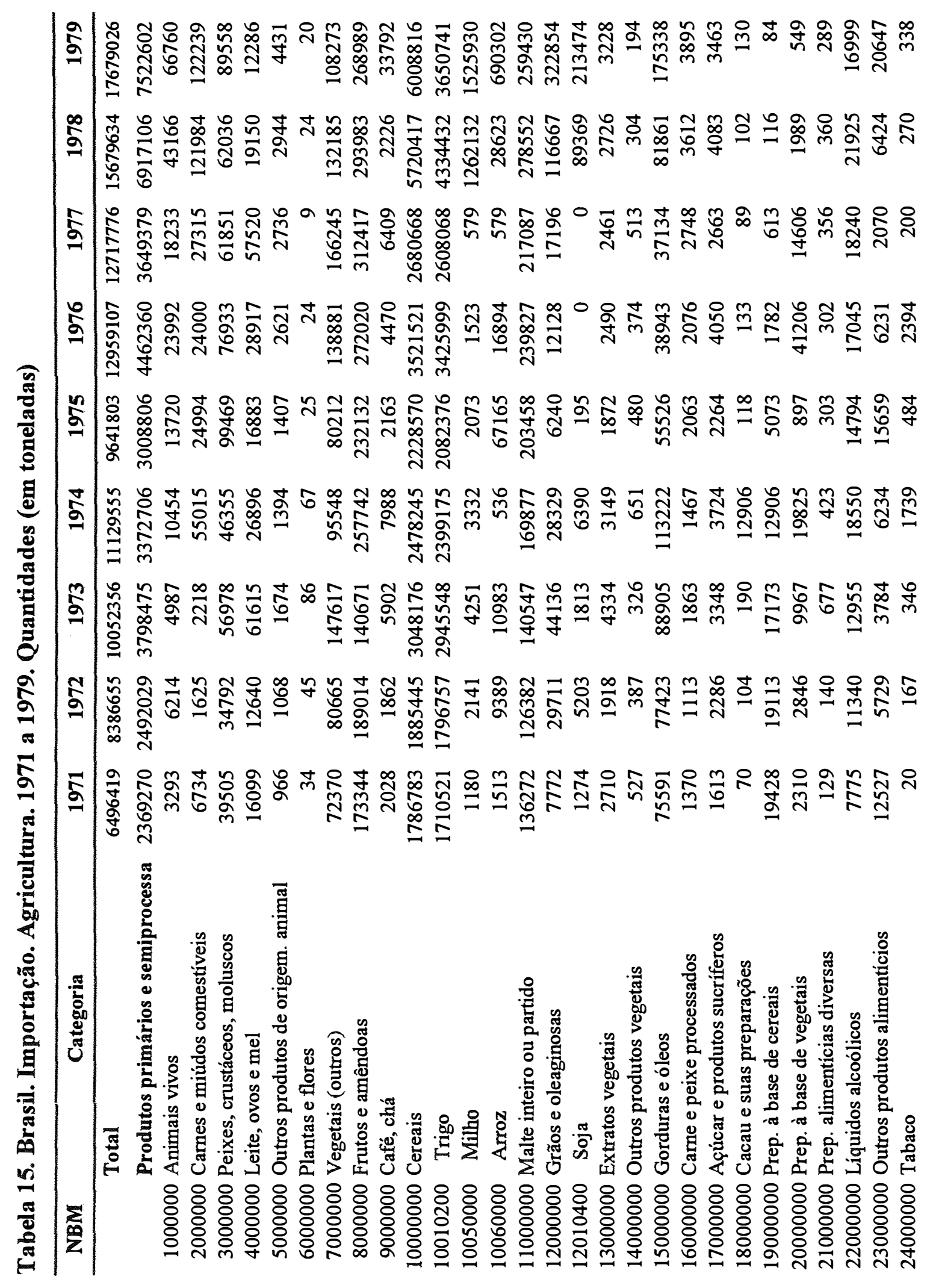









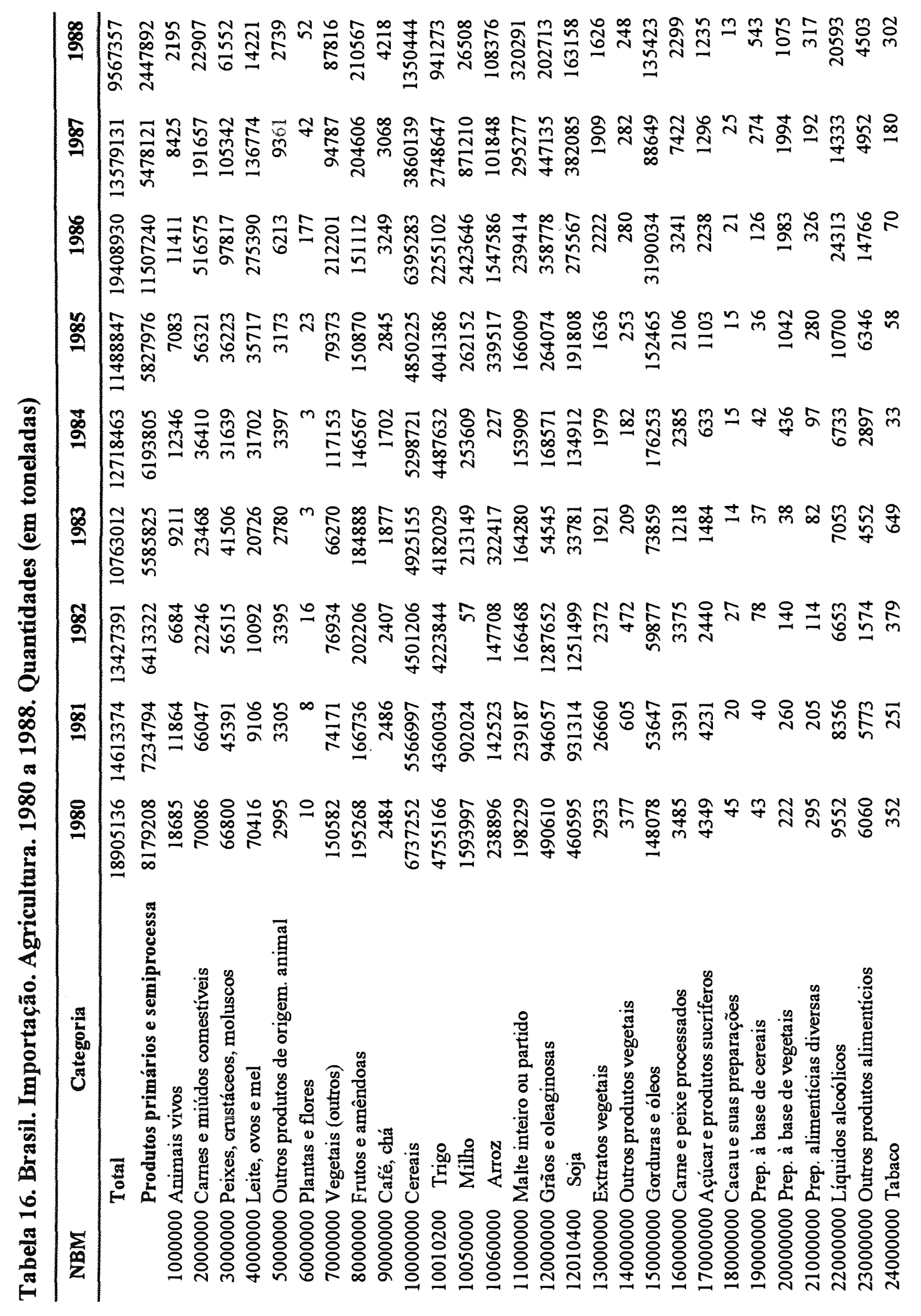














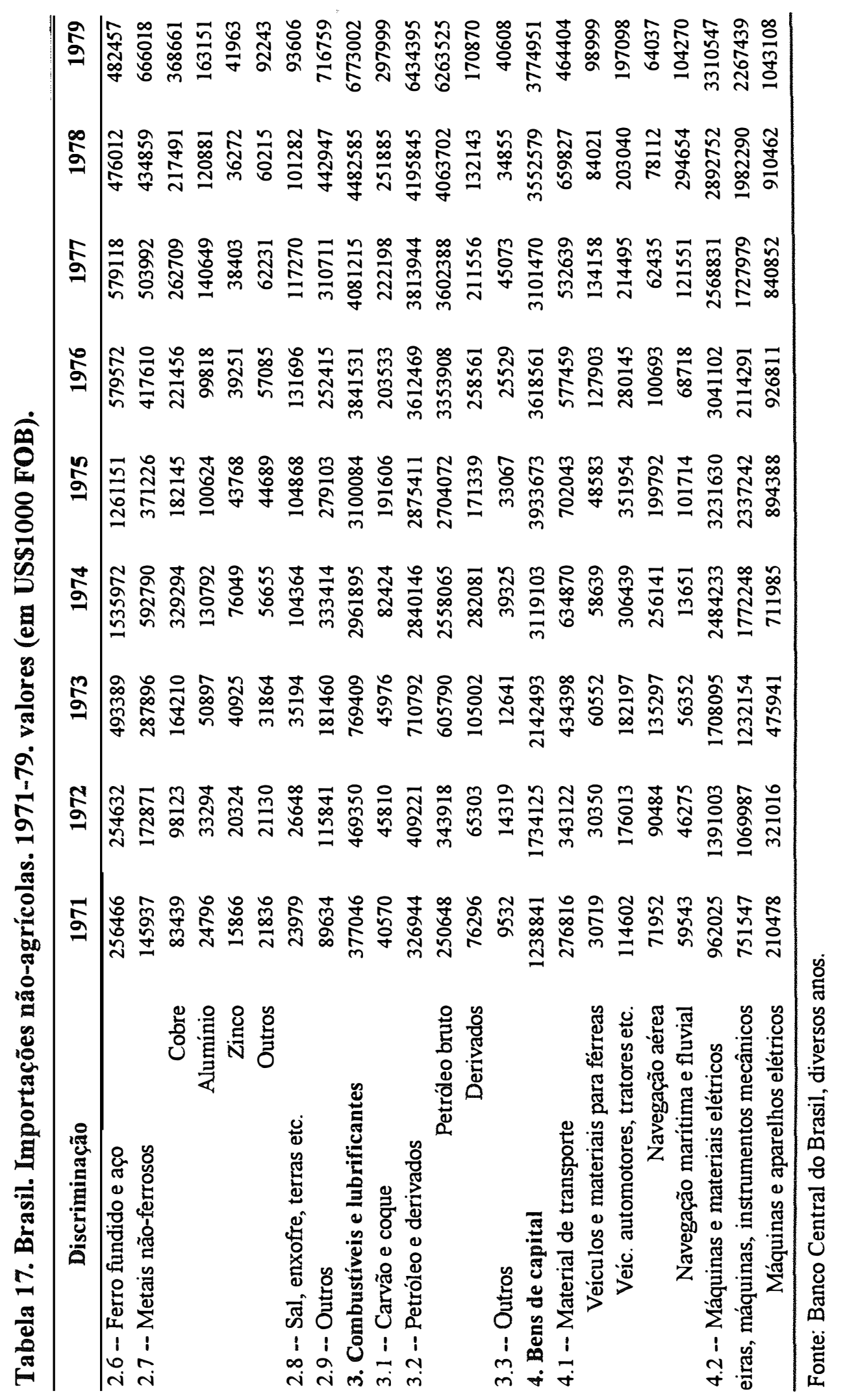









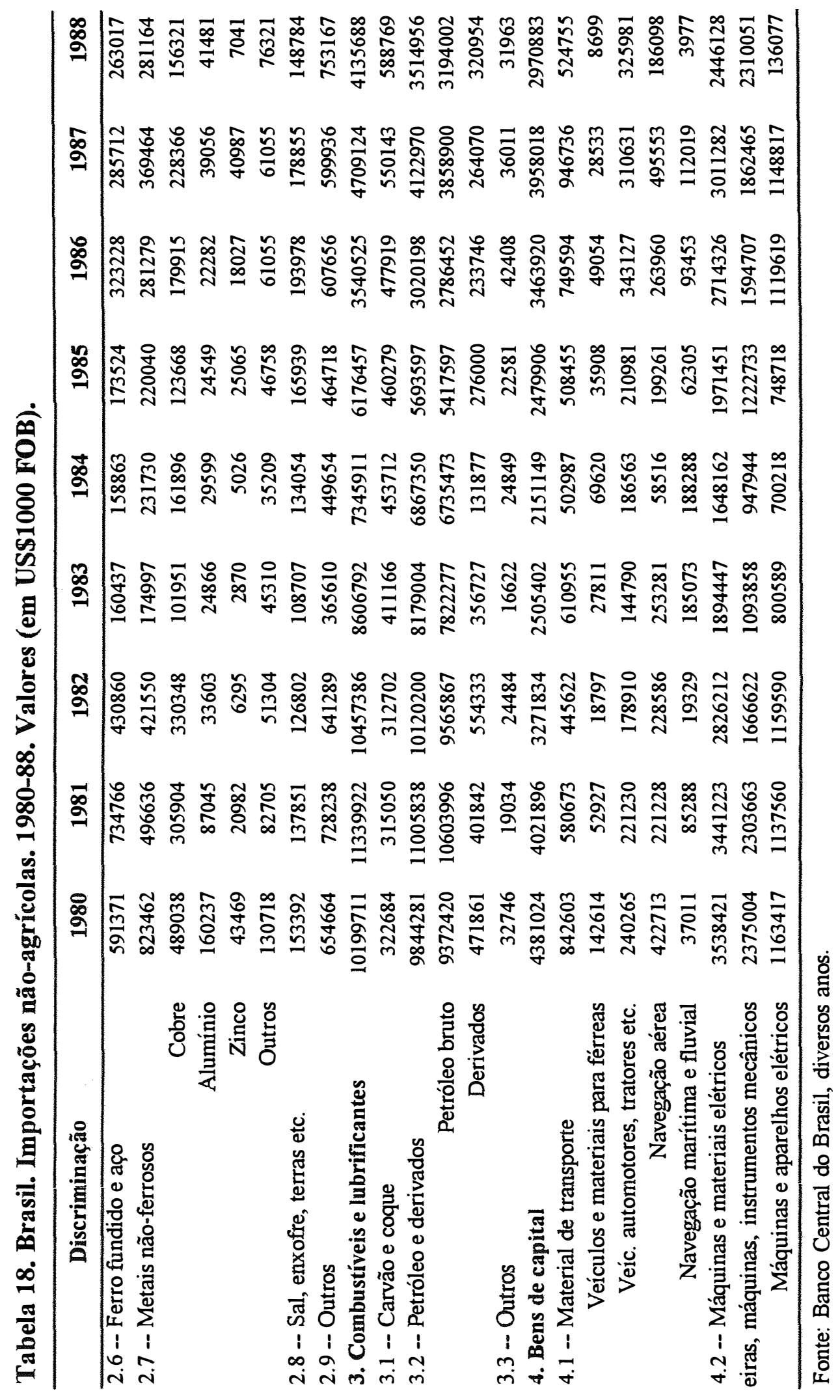




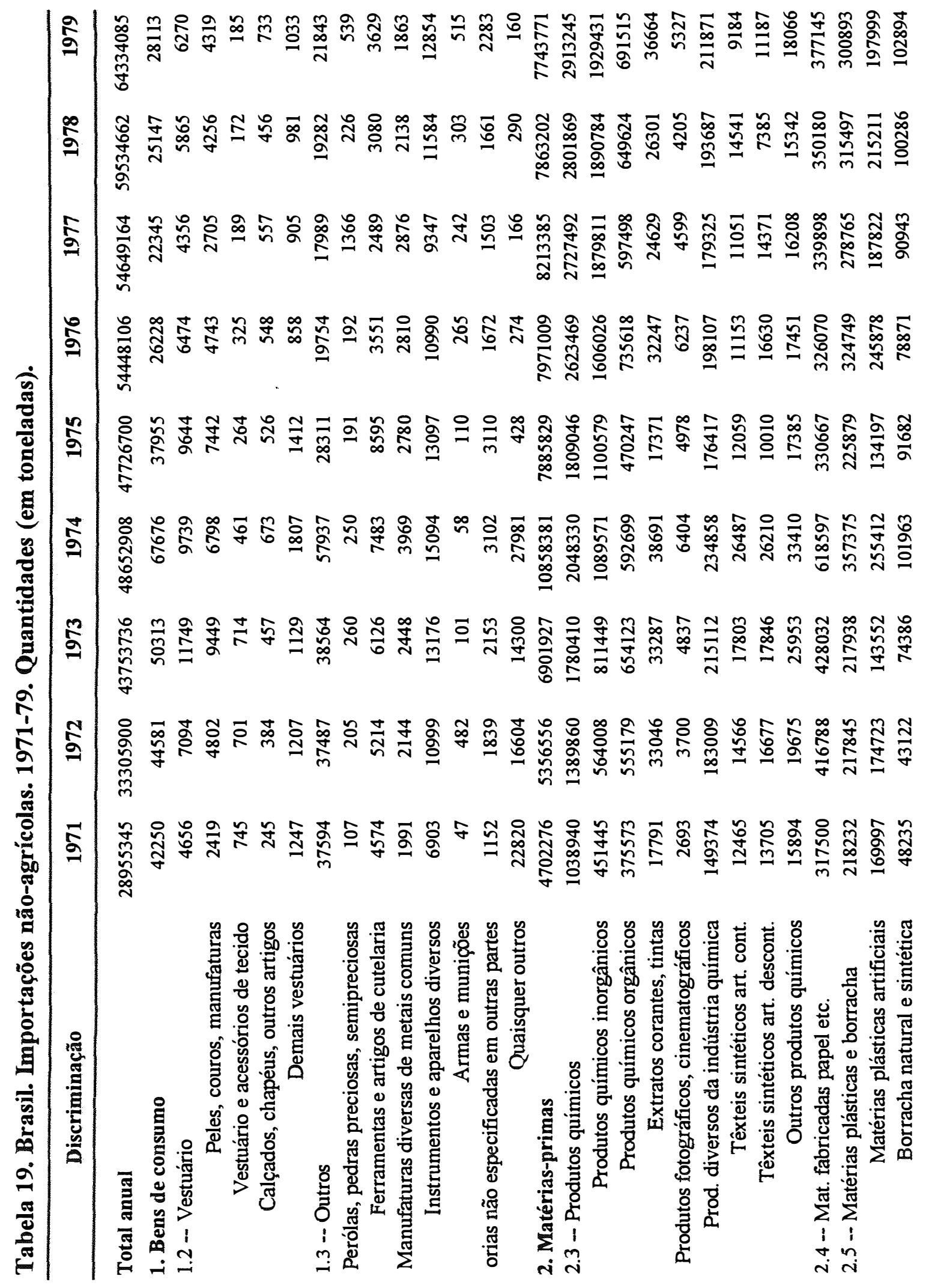




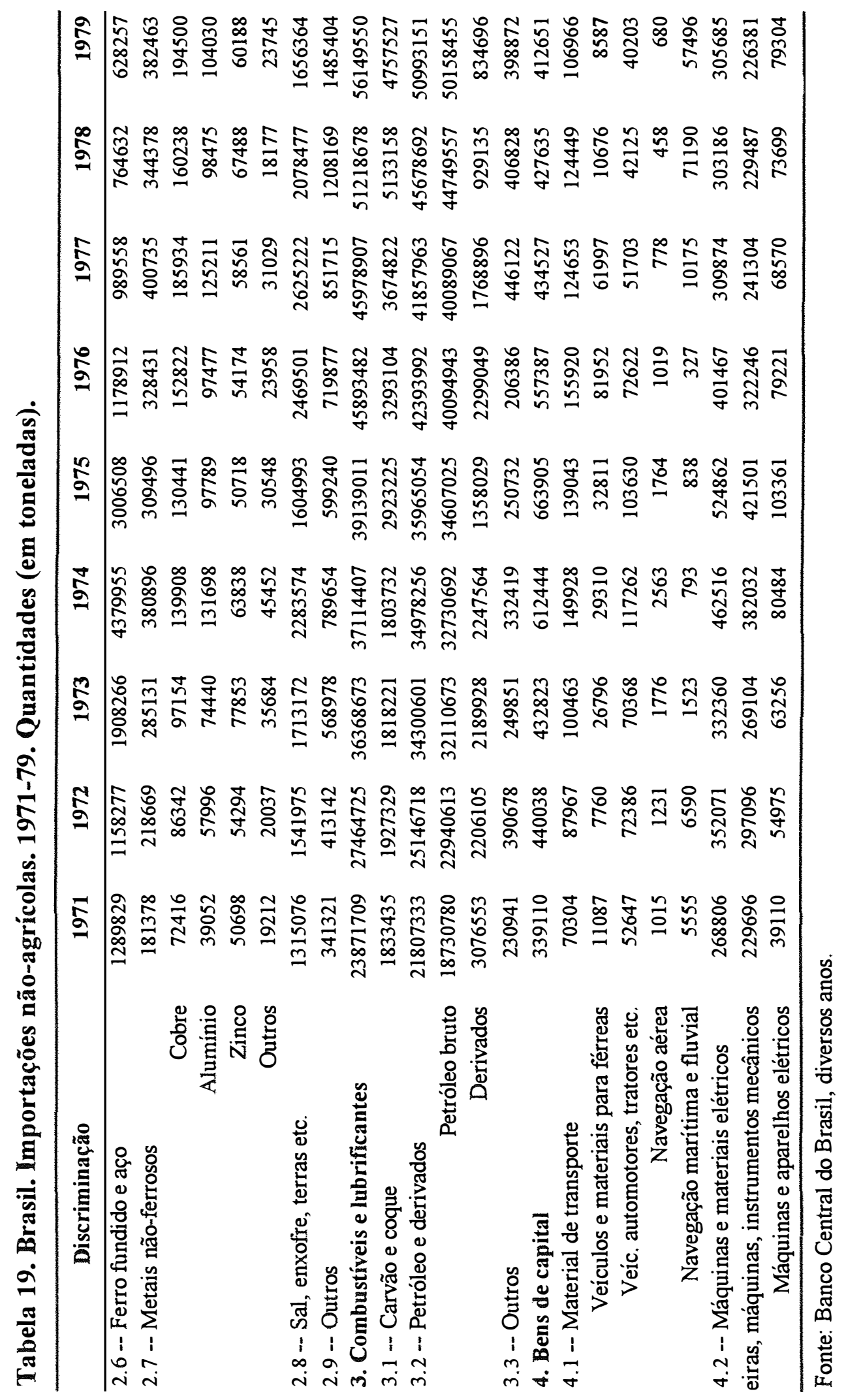




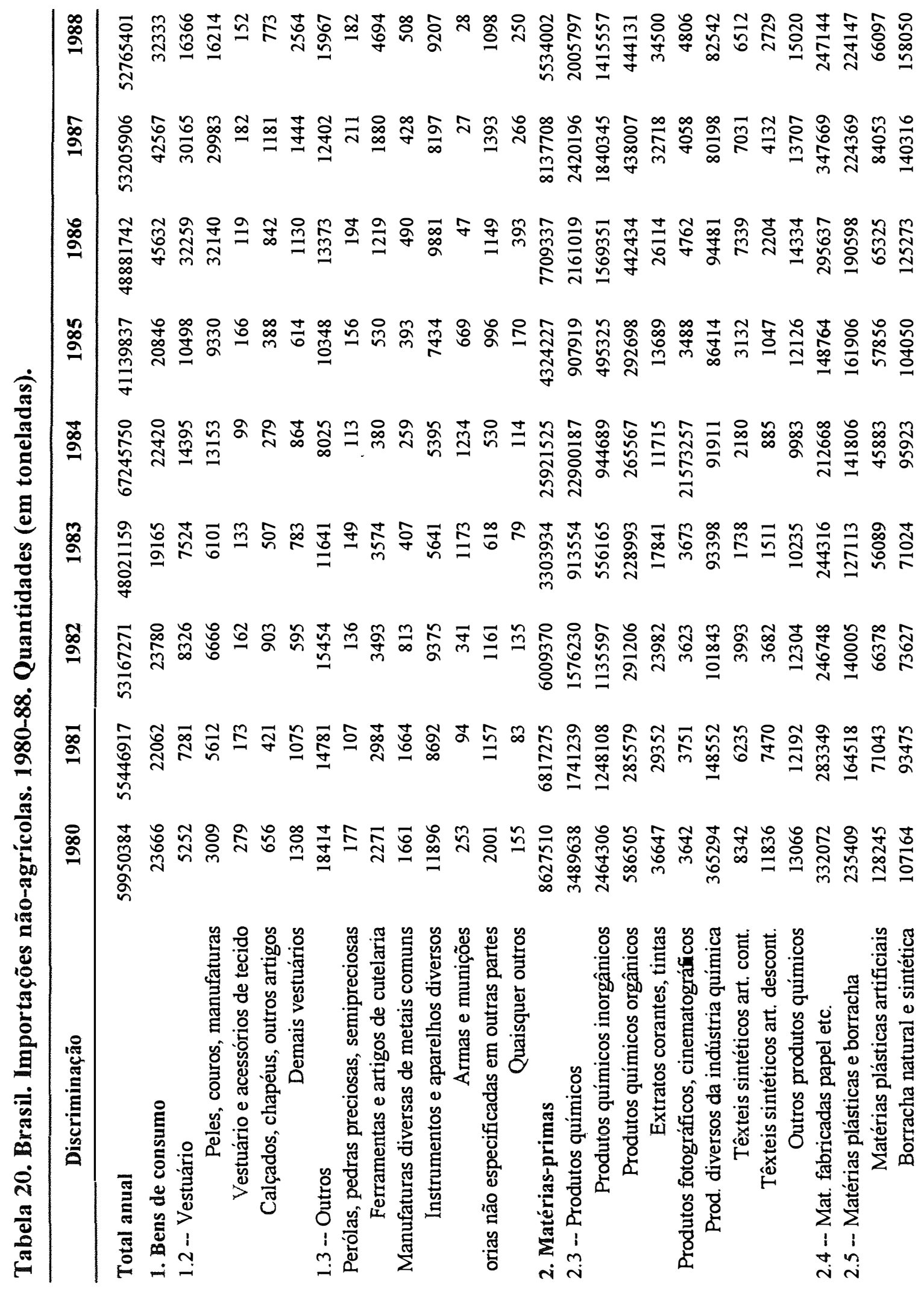




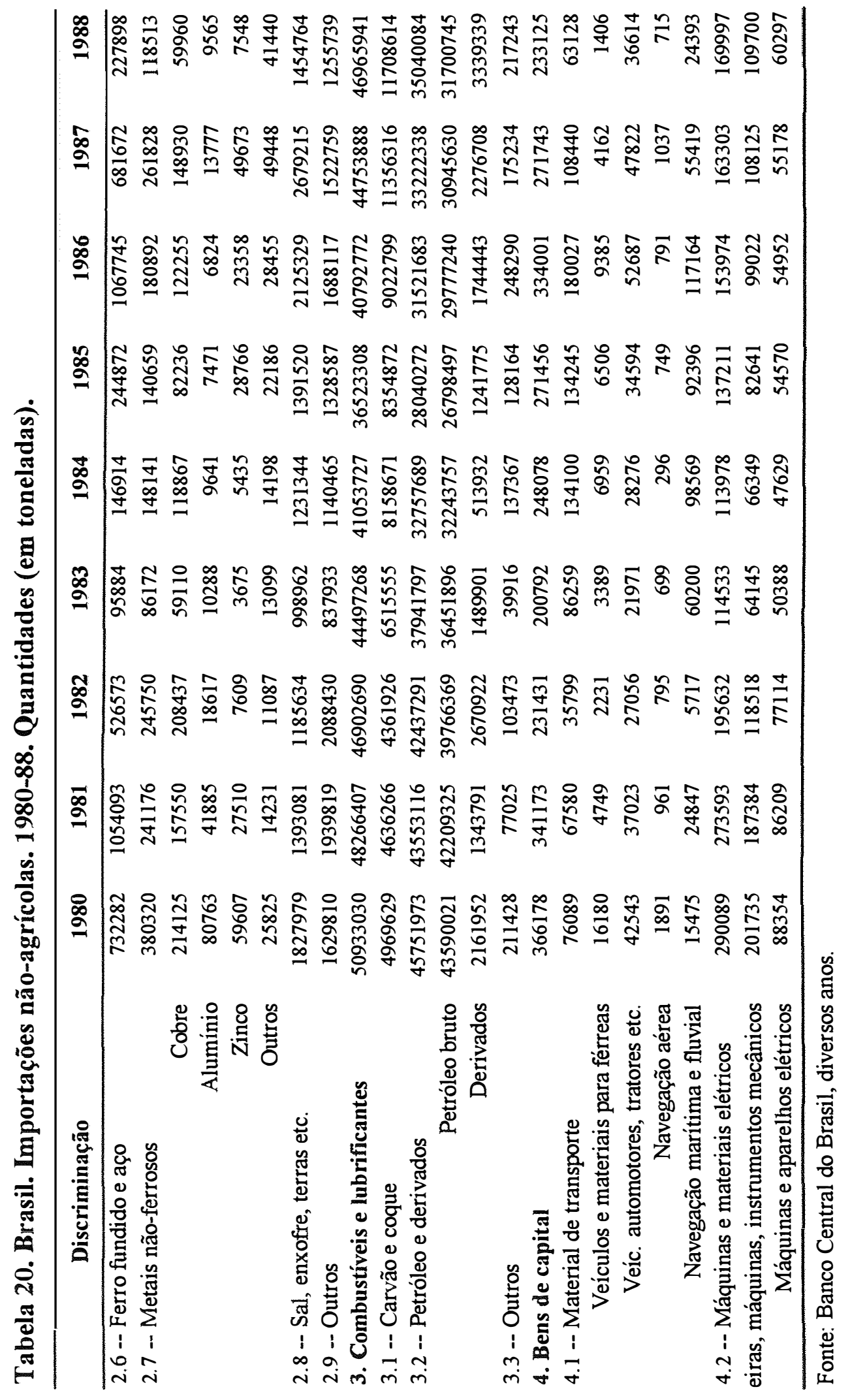




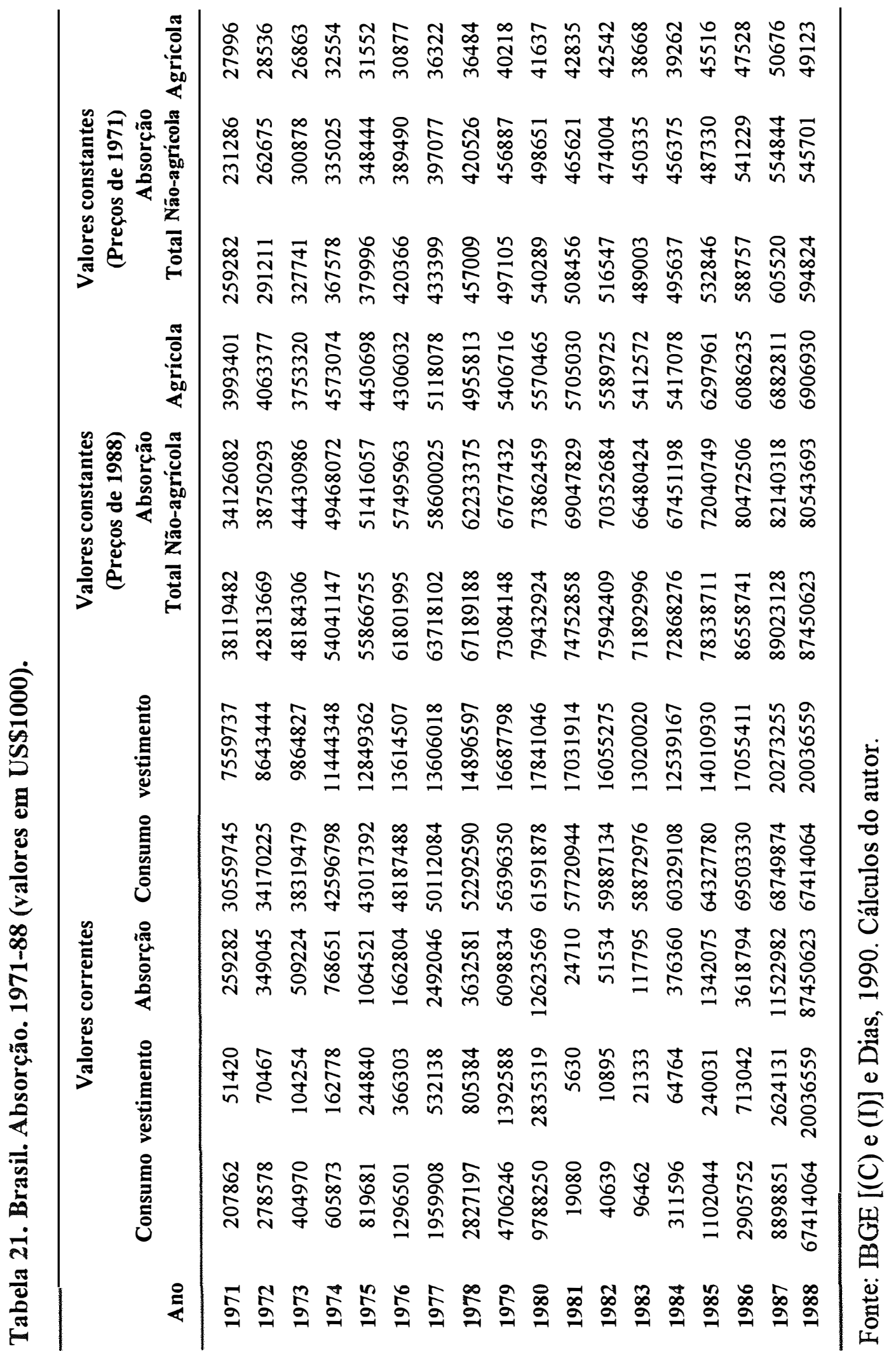


Tabela 22. Brasil. Valor da Disponibilidade Doméstica (VDD) da produção agropecuária nacional e Grau de Abertura (GA), 1962 a 1988 (base: 1988).

\begin{tabular}{|c|c|c|}
\hline Ano & VDD & GA \\
\hline 1962 & 3225827 & 18,29 \\
\hline 1963 & 3146878 & 16,95 \\
\hline 1964 & 2943041 & 17,41 \\
\hline 1965 & 3843331 & 15,41 \\
\hline 1966 & 3149919 & 19,91 \\
\hline 1967 & 3514760 & 18,07 \\
\hline 1968 & 3359202 & 20,96 \\
\hline 1969 & 3423753 & 23,23 \\
\hline 1970 & 3445647 & 23,05 \\
\hline 1971 & 3813300 & 22,31 \\
\hline 1972 & 3868225 & 24,33 \\
\hline 1973 & 3481176 & 27,63 \\
\hline 1974 & 4266619 & 22,57 \\
\hline 1975 & 4212450 & 25,30 \\
\hline 1976 & 3979429 & 29,00 \\
\hline 1977 & 4832445 & 24,00 \\
\hline 1978 & 4527829 & 24,96 \\
\hline 1979 & 4907715 & 22,87 \\
\hline 1980 & 5107449 & 26,15 \\
\hline 1981 & 5273331 & 30,14 \\
\hline 1982 & 5222412 & 28,89 \\
\hline 1983 & 5132513 & 32,26 \\
\hline 1984 & 5085039 & 34,97 \\
\hline 1985 & 5973127 & 30,93 \\
\hline 1986 & 5417385 & 28,86 \\
\hline 1987 & 6463110 & 28,64 \\
\hline 1988 & 6675562 & 26,22 \\
\hline
\end{tabular}

Fonte: Dias (1990). 
Tabela 23. Brasil. Decomposição ${ }^{1}$ das variações dos saldos em conta corrente, entre cada ano no período 1974/78 e o ano-base de 1973 (todas as variáveis são proporções do PNB). Base de preços 1986-88.

\begin{tabular}{|c|c|c|c|c|c|c|c|}
\hline Fatores explicativos & & 1974 & 1975 & 1976 & 1977 & 1978 & Média \\
\hline \multicolumn{8}{|l|}{ Choques externos } \\
\hline \multirow[t]{4}{*}{ Variação das relações de troca } & $\mathrm{P}_{\mathrm{m}} \mathrm{a} / \mathrm{P}_{\mathrm{y}}$ & 0,45 & 0,28 & $-0,06$ & $-0,15$ & $-0,31$ & 0,42 \\
\hline & $P_{m} n / P_{y}^{y}$ & 1,76 & 1,62 & 1,96 & 1,17 & $-0,05$ & 1,29 \\
\hline & $P_{x} a / P_{y}^{y}$ & $-0,49$ & 1,13 & 0,73 & $-0,13$ & 0,77 & 0,40 \\
\hline & $P_{x} n / P_{y}^{y}$ & 0,43 & 0,03 & $-0,06$ & $-0,05$ & 0,15 & 0,10 \\
\hline Taxa de juros & r & 0,06 & 0,19 & 0,06 & 0,08 & 0,08 & 0,10 \\
\hline \multirow[t]{2}{*}{ Variação do comércio mundial } & $W^{a} / U^{r}$ & 0,73 & 0,66 & 0,76 & 0,91 & 0,58 & 0,73 \\
\hline & $\mathrm{W}^{\mathrm{n}} / \mathrm{U}$ & 0,05 & 0,29 & 0,26 & 0,27 & 0,25 & 0,22 \\
\hline \multirow[t]{3}{*}{ Outras variáveis externas } & $\mathrm{K} / \mathrm{Y}$ & $-0,08$ & 0,28 & 0,47 & 0,46 & 0,60 & 0,35 \\
\hline & $\mathrm{V}_{\mathrm{d}} / \mathrm{Y}^{r}$ & 0,18 & $-0,09$ & $-0,06$ & $-0,29$ & $-0,29$ & $-0,11$ \\
\hline & $\mathrm{T} / \mathrm{Y}^{\prime}$ & $-0,03$ & $-0,03$ & $-0,03$ & $-0,03$ & 0,00 & $-0,02$ \\
\hline \multicolumn{8}{|l|}{ Políticas Domésticas } \\
\hline \multirow[t]{2}{*}{ Gasto doméstico } & $\mathrm{A}_{\mathrm{a}} / \mathrm{U}$ & 0,20 & 0,06 & $-0,13$ & 0,06 & 0,00 & 0,04 \\
\hline & $A_{n} / U$ & 0,21 & 0,17 & 0,29 & 0,08 & 0,20 & 0,19 \\
\hline \multirow[t]{4}{*}{ Competitividade externa } & $\mathrm{J}_{\mathrm{a}} / \mathrm{A}_{\mathrm{a}}$ & $-0,05$ & $-0,27$ & 0,02 & $-0,36$ & 0,16 & $-0,1$ \\
\hline & $J_{n} / A_{n}$ & 1,75 & 0,49 & $-1,08$ & $-1,38$ & $-0,63$ & $-0,17$ \\
\hline & $\mathrm{z}_{\mathrm{a}} / \mathrm{w}_{\mathrm{a}}$ & 0,69 & 0,24 & 0,15 & 0,40 & 1,14 & 0,52 \\
\hline & $Z_{n} / W_{n}$ & $-0,44$ & $-1,15$ & $-0,39$ & $-0,50$ & $-1,10$ & $-0,72$ \\
\hline Choques externos & & 2,98 & 4,20 & 3,65 & 2,10 & 1,47 & 2,88 \\
\hline Outras variáveis externas & & 0,07 & 0,16 & 0,38 & 0,14 & 0,31 & 0,21 \\
\hline Políticas domésticas & & 2,35 & $-0,47$ & $-1,14$ & $-1,71$ & $-0,23$ & $-0,24$ \\
\hline \multirow{3}{*}{$\begin{array}{l}\text { Saldo em transações } \\
\text { correntes }\end{array}$} & Calculado & 5,40 & 3,88 & 2,89 & 0,53 & 1,54 & 2,85 \\
\hline & Observado & 4,51 & 3,22 & 1,95 & 0,29 & 1,54 & 2,30 \\
\hline & Resíduo & 0,89 & 0,66 & 0,94 & 0,24 & 0,01 & 0,55 \\
\hline Setor agrícola & & 1,23 & 1,33 & 0,93 & 0,42 & 1,39 & 1,06 \\
\hline
\end{tabular}

Fonte: cálculos do autor.

1 Os fatores de decomposição foram calculados utilizando-se como pesos os valores observados para o ano base. 
Tabela 24. Brasil. Decomposição ${ }^{1}$ das variações dos saldos em conta corrente, entre cada ano no período 1979/83 e o ano-base de 1978 (todas as variáveis são proporções do PNB). Base de preços 1986-88.

\begin{tabular}{|c|c|c|c|c|c|c|c|}
\hline Fatores explicativos & & 1979 & 1980 & 1981 & 1982 & 1983 & Média \\
\hline \multicolumn{8}{|l|}{ Choques externos } \\
\hline \multirow[t]{4}{*}{ Variação das relações de troca } & $\mathrm{P}_{\mathrm{m}} \mathrm{a} / \mathrm{P}_{\mathrm{y}}$ & 0,18 & 0,48 & 0,02 & $-0,28$ & 0,59 & 0,20 \\
\hline & $P_{m} n / P_{y}^{0}$ & 1,79 & 5,55 & 4,69 & 4,47 & 5,63 & 4,43 \\
\hline & $P_{x} a / P_{y}$ & $-0,36$ & $-0,70$ & 1,00 & 1,59 & 0,46 & 0,40 \\
\hline & $P_{x} n / P_{y}$ & $-0,08$ & $-0,11$ & 0,72 & 0,68 & $-0,11$ & 0,22 \\
\hline Taxa de juros & $\mathrm{r}$ & 0,32 & 0,73 & 1,30 & 1,63 & 0,85 & 0,97 \\
\hline \multirow[t]{2}{*}{ Variação do comércio mundial } & $\mathrm{W}^{\mathrm{a}} / \mathrm{U}$ & $-0,05$ & 0,18 & $-0,27$ & $-0,25$ & $-0,58$ & $-0,19$ \\
\hline & $\mathrm{W}^{\mathrm{n}} / \mathrm{U}^{\mathrm{r}}$ & 0,04 & 0,23 & $-0,05$ & 0,01 & $-0,41$ & $-0,04$ \\
\hline \multirow[t]{3}{*}{ Outras variáveis externas } & $\mathrm{K} / \mathrm{Y}^{\prime}$ & 0,23 & 0,67 & 0,94 & 1,22 & 2,71 & 1,15 \\
\hline & $\mathrm{V}_{\mathrm{d}} / \mathrm{Y}^{\prime}$ & 0,56 & 0,52 & 0,40 & 0,97 & 0,83 & 0,66 \\
\hline & $\mathrm{T} / \mathrm{Y}^{\prime}$ & $-0,03$ & 0,04 & 0,04 & $-0,04$ & 0,02 & 0,01 \\
\hline \multicolumn{8}{|l|}{ Políticas Domésticas } \\
\hline \multirow[t]{2}{*}{ Gasto doméstico } & $\mathrm{A}_{\mathrm{a}} / \mathrm{U}^{\prime}$ & 0,06 & $-0,02$ & 0,10 & 0,09 & 0,02 & 0,05 \\
\hline & $\mathrm{A}_{\mathrm{n}} / \mathrm{U}^{\prime}$ & 0,16 & 0,23 & 0,10 & 0,24 & 0,19 & 0,18 \\
\hline \multirow[t]{4}{*}{ Competitividade externa } & $\mathrm{J}_{\mathrm{a}} / \mathrm{A}_{\mathrm{a}}$ & 0,18 & 0,17 & $-0,05$ & $-0,03$ & $-0,75$ & $-0,10$ \\
\hline & $J_{n} / A_{n}$ & $-0,72$ & $-2,74$ & $-2,81$ & $-4,18$ & $-4,57$ & 3,00 \\
\hline & $\mathrm{z}_{\mathrm{a}} / \mathrm{w}_{\mathrm{a}}$ & 0,32 & $-0,75$ & $-1,52$ & $-1,01$ & $-1,86$ & $-0,96$ \\
\hline & $\mathrm{Z}_{\mathrm{n}} / \mathrm{W}_{\mathrm{n}}$ & $-0,54$ & $-1,68$ & $-3,01$ & $-2,26$ & $-3,75$ & $-2,25$ \\
\hline Choques externos & & 1,84 & 6,37 & 7,40 & 7,86 & 6,43 & 5,98 \\
\hline Outras variáveis externas & & 0,77 & 1,23 & 1,38 & 2,15 & 3,56 & 1,82 \\
\hline Políticas domésticas & & $-0,54$ & $-4,80$ & $-7,19$ & $-7,15$ & $-10,73$ & $-6,08$ \\
\hline \multirow{3}{*}{$\begin{array}{l}\text { Saldo em transações } \\
\text { correntes }\end{array}$} & Calculado & 2,06 & 2,80 & 1,60 & 2,86 & $-0,74$ & 1,72 \\
\hline & Observado & 1,39 & 2,06 & 1,06 & 2,51 & $-0,04$ & 1,40 \\
\hline & Residuo & 0,67 & 0,74 & 0,54 & 0,35 & $-0,70$ & 0,32 \\
\hline Setor agrícola & & 0,30 & $-0,34$ & $-0,49$ & 0,04 & $-1,53$ & $-0,40$ \\
\hline
\end{tabular}

Fonte: cálculos do autor.

1 Os fatores de decomposição foram calculados utilizando-se como pesos os valores observados para o ano base. 
Tabela 25. Brasil. Decomposição ${ }^{1}$ das variações dos saldos em conta corrente, entre cada ano no período 1984/88 e o ano-base de 1983 (todas as variáveis são proporções do PNB). Base de preços 1986-88.

Fatores explicativos

\section{Choques externos}

Variação das relações de troca

Taxa de juros

Variação do comércio mundial

Outras variáveis externas

Políticas Domésticas

Gasto doméstico

Competitividade externa

Choques externos

Outras variáveis externas

Políticas domésticas

Saldo em transações correntes

\section{$\begin{array}{llllll}1984 & 1985 & 1986 & 1987 & 1988 & \text { Média }\end{array}$}

$\begin{array}{rrrrrrr}\mathrm{K} / \mathrm{Y}^{\prime} & 0,56 & 0,36 & -0,20 & -0,15 & -0,49 & 0,02 \\ \mathrm{~V}_{\mathrm{d}} / \mathrm{Y}^{\prime} & -0,50 & -0,50 & -0,32 & -0,66 & -0,64 & -0,52 \\ \mathrm{~T} / \mathrm{Y}^{\prime} & 0,03 & 0,01 & -0,02 & -0,03 & -0,03 & -0,01\end{array}$

$$
\begin{array}{llrrrrr}
\mathrm{A}_{\mathrm{a}} / \mathrm{U}^{\prime} & -0,05 & 0,04 & -0,01 & 0,01 & -0,02 & -0,01 \\
\mathrm{~A}_{\mathrm{n}} / \mathrm{U}^{\prime} & -0,28 & -0,39 & -0,21 & -0,33 & -0,39 & -0,32
\end{array}
$$

$\begin{array}{rrrrrrr}\mathrm{J}_{\mathrm{a}} / \mathrm{A}_{\mathrm{a}} & 0,31 & 0,11 & 1,17 & 0,39 & -0,13 & 0,37 \\ \mathrm{~J}_{\mathrm{n}} / \mathrm{A}_{\mathrm{n}} & 1,44 & 1,02 & 2,10 & 0,56 & -0,71 & 0,88 \\ \mathrm{Z}_{\mathrm{a}} / \mathrm{W}_{\mathrm{a}} & -0,01 & -0,30 & 1,27 & 0,40 & 0,69 & 0,41 \\ \mathrm{Z}_{\mathrm{n}} / \mathrm{W}_{\mathrm{n}} & -1,72 & -1,08 & 1,59 & 1,65 & 0,20 & 0,13\end{array}$

$\begin{array}{llllll}-3,68 & -2,94 & -6,22 & -4,42 & -3,71 & -4,19\end{array}$

$\begin{array}{llllll}0,09 & -0,13 & -0,54 & -0,84 & -1,15 & -0,51\end{array}$

$\begin{array}{llllll}-0,31 & -0,61 & 5,91 & 2,68 & -0,36 & 1,46\end{array}$

$\begin{array}{lllllll}\text { Calculado } & -3,90 & -3,67 & -0,85 & -2,58 & -5,22 & -3,24\end{array}$

$\begin{array}{lllllll}\text { Observado } & -3,56 & -3,43 & -1,50 & -3,04 & -4,79 & -3,26\end{array}$

$\begin{array}{lllllll}\text { Resíduo } & -0,34 & -0,24 & 0,64 & 0,46 & -0,43 & 0,02\end{array}$

$$
\begin{array}{lllllll}
\text { Setor agrícola } & -0,55 & 0,15 & 1,77 & 1,25 & 0,92 & 0,71
\end{array}
$$

Fonte: cálculos do autor.

${ }^{1}$ Os fatores de decomposição foram calculados utilizando-se como pesos os valores observados para o ano base. 
Tabela 26. Brasil, 1970-1989. Índices de taxas de câmbio efetivas reais (e) para a moeda nacional $(1971=100,0)$.

\begin{tabular}{lcc}
\hline Anos & e(IPA) & e(TNT) \\
\hline 1970 & 98,5 & 98,6 \\
1971 & 100,0 & 100,0 \\
1972 & 103,2 & 105,0 \\
1973 & 108,5 & 114,4 \\
1974 & 107,2 & 114,3 \\
1975 & 112,2 & 118,1 \\
1976 & 108,3 & 115,0 \\
1977 & 107,6 & 113,3 \\
1978 & 113,6 & 118,6 \\
1979 & 125,8 & 134,2 \\
1980 & 133,2 & 160,5 \\
1981 & 112,9 & 137,5 \\
1982 & 105,3 & 125,3 \\
1983 & 125,0 & 164,5 \\
1984 & 115,4 & 172,0 \\
1985 & 113,3 & 169,9 \\
1986 & 115,1 & 169,0 \\
1987 & 117,1 & 160,4 \\
1988 & 104,4 & 145,4 \\
1989 & 82,0 & 113,9 \\
\hline
\end{tabular}

Fonte: Zini Jr. (1988).

1 e(IPA): (e) deflacionada pelo Índice de Preços no Atacado (IPA).

2 e(TNT): deflacionada pela relação de preços tradables/não-tradables. 
Tabela 27. Brasil: decomposição dos aumentos dos deficits em conta corrente entre cada ano no período 1974/78 e o ano-base de $1973^{\text {a }}$ (todas as variáveis são proporções do PIB potencial)

\begin{tabular}{|c|c|c|c|c|c|}
\hline Fatores explicativos & 1974 & 1975 & 1976 & 1977 & 1978 \\
\hline 1 -- Choques externos & 2,46 & 3,90 & 1,43 & 0,45 & 2,00 \\
\hline $\begin{array}{l}1.1 \text {-- Deterioração nas relações de troca } b \\
1.2 \text {-- Choques dos juros } c \\
1.3 \text {-- Retarde do crescimento do comércio mundial }\end{array}$ & $\begin{array}{l}2,01 \\
0,03 \\
0,42\end{array}$ & $\begin{array}{l}2,45 \\
0,18 \\
1,27\end{array}$ & $\begin{array}{r}0,60 \\
-0,06 \\
0,89\end{array}$ & $\begin{array}{r}-0,70 \\
-0,04 \\
1,20\end{array}$ & $\begin{array}{r}0,75 \\
-0,03 \\
1,28\end{array}$ \\
\hline 2 -- Ônus da divida externa $d$ & $-0,07$ & 0,33 & 0,59 & 0,57 & 0,67 \\
\hline $\begin{array}{l}\text { 3-- Politicas internas } \mathrm{e} \\
3.1 \text {-- Recessão doméstica } \mathrm{f} \\
\text { 3.1.1 -- Cortes do investimento fixo } \mathrm{g} \\
\text { 3.1.2 -- Contração do produto } \mathrm{h} \\
\text { 3.2 -- Competitividade externa } \mathrm{i} \\
\text { 3.2.1 -- Penetração das exportações } \mathrm{j} \\
\text { 3.2.2 -- Substituição das importações } 1 \\
\text { 3.3 -- Conteção da remessa de lucros } \mathrm{m}\end{array}$ & $\begin{array}{r}2,18 \\
0,46 \\
(0,16) \\
(0,00) \\
2,00 \\
(0,11) \\
(1,89) \\
0,02\end{array}$ & $\begin{array}{r}-1,09 \\
0,23 \\
(0,31) \\
(-0,08) \\
-1,30 \\
(-1,06) \\
(-0,24) \\
-0,02\end{array}$ & $\begin{array}{r}-0,19 \\
0,37 \\
(0,30) \\
(0,07) \\
-0,60 \\
(0,01) \\
(-0,61) \\
0,04\end{array}$ & $\begin{array}{r}-0,85 \\
0,02 \\
(0,09) \\
(-0,07) \\
-0,92 \\
(0,05) \\
(-1,42) \\
0,05\end{array}$ & $\begin{array}{r}-2,06 \\
-0,14 \\
(0,06) \\
(-0,20) \\
-1,95 \\
(-0,41) \\
(-1,54) \\
0,03\end{array}$ \\
\hline 4 -- Aumento calculado do deficit $[(1)+(2)+(3)]$ & 4,57 & 3,14 & 1,83 & 0,18 & 0,61 \\
\hline 5 -- Efeitos de interação e erros de arredondamento & $-0,28$ & $-0,11$ & $-0,06$ & 0,02 & 0,17 \\
\hline 6 -- Aumento observado do deficit $[(4)+(5)]$ & 4,29 & 3,03 & 1,77 & 0,20 & 0,78 \\
\hline
\end{tabular}

a Os fatores de decomposição foram calculados usando uma média entre as ponderações do ano corrente e do ano-base.

b Valor negativo significa melhoria das relações de troca.

c Valor negativo significa redução das taxas de juros.

d Valor negativo significa redução da razão entre o passivo externo e o PIB potencial.

e Valor positivo significa politicas que aumentam o deficit.

f Valor positivo significa expansão econômica.

$\mathrm{g}$ Valor positivo significa aumento do investimento.

$\mathrm{h}$ Valor positivo significa aumento do produto.

i Valor positivo significa menor competitividade externa.

j Valor positivo significa contração das exportações.

${ }^{1}$ Valor positivo significa aumento das importações.

$\mathrm{m}$ Valor positivo significa aumento da remessa de lucros.

Fonte: Bacha (1984). 
Tabela 28. Brasil: decomposição dos aumentos dos deficits em conta corrente entre cada ano no período 1979/83 e o ano-base de 1978 a (todas as variáveis são proporções do PIB potencial)

\begin{tabular}{|c|c|c|c|c|c|}
\hline Fatores explicativos & 1979 & 1980 & 1981 & 1982 & 1983 \\
\hline 1 -- Choques externos & 1,08 & 3,42 & 5,00 & 5,64 & 5,60 \\
\hline $\begin{array}{l}1.1 \text {-- Deterioração nas relações de troca } b \\
1.2 \text {-- Choques dos juros } c \\
1.3 \text {-- Retarde do crescimento do comércio mundial }\end{array}$ & $\begin{array}{r}0,85 \\
0,30 \\
-0,07\end{array}$ & $\begin{array}{l}2,35 \\
0,80 \\
0,27\end{array}$ & $\begin{array}{l}2,87 \\
1,23 \\
0,90\end{array}$ & $\begin{array}{l}2,98 \\
1,47 \\
1,19\end{array}$ & $\begin{array}{l}3,47 \\
0,61 \\
1,52\end{array}$ \\
\hline 2 -- Ônus da dívida externa $d$ & 0,21 & 0,62 & 0,65 & 0,90 & 0,83 \\
\hline $\begin{array}{l}\text { 3 -- Políticas internas } \mathrm{e} \\
\text { 3.1 -- Recessão doméstica } \mathrm{f} \\
\text { 3.1.1 -- Cortes do investimento fixo } \mathrm{g} \\
\text { 3.1.2 -- Contração do produto } \mathrm{h} \\
\text { 3.2 -- Competitividade externa } \mathrm{i} \\
\text { 3.2.1 -- Penetração das exportações } \mathrm{j} \\
\text { 3.2.2 -- Substituição das importações } \\
\text { 3.3 -- Conteção da remessa de lucros } \mathrm{m}\end{array}$ & $\begin{array}{r}0,12 \\
-0,04 \\
(-0,04) \\
(0,00) \\
0,13 \\
(0,00) \\
(0,13) \\
0,03\end{array}$ & $\begin{array}{r}-2,06 \\
0,13 \\
(-0,06) \\
(0,19) \\
-2,02 \\
(-1,40) \\
(-0,62) \\
-0,17\end{array}$ & $\begin{array}{r}-5,00 \\
-0,86 \\
(-0,28) \\
(-0,58) \\
-3,96 \\
(-2,35) \\
(-1,61) \\
-0,18\end{array}$ & $\begin{array}{r}-4,47 \\
-1,13 \\
(-0,34) \\
(-0,79) \\
-3,34 \\
(-1,65) \\
(-1,69) \\
-0,06\end{array}$ & $\begin{array}{r}-6,35 \\
-1,39 \\
(-0,40) \\
(-0,99) \\
-4,90 \\
(-2,25) \\
(-2,65) \\
-0,06\end{array}$ \\
\hline 4 -- Aumento calculado do deficit $[(1)+(2)+(3)]$ & 1,41 & 1,98 & 0,65 & 2,08 & $-1,45$ \\
\hline 5 -- Efeitos de interação e erros de arredondamento & $-0,07$ & 0,00 & $-0,02$ & $-0,63$ & 0,25 \\
\hline 6 -- Aumento observado do deficit $[(4)+(5)]$ & 1,34 & 2,07 & 0,63 & 1,37 & $-1,20$ \\
\hline
\end{tabular}

a Os fatores de decomposição foram calculados usando uma média entre as ponderações do ano corrente e do ano-base.

b Valor negativo significa melhoria das relações de troca.

c Valor negativo significa redução das taxas de juros.

d Valor negativo significa redução da razão entre o passivo externo e o PIB potencial.

e Valor positivo significa políticas que aumentam o deficit.

f Valor positivo significa expansão econômica.

$\mathrm{g}$ Valor positivo significa aumento do investimento.

$\mathrm{h}$ Valor positivo significa aumento do produto.

i Valor positivo significa menor competitividade externa.

j Valor positivo significa contração das exportações.

1 Valor positivo significa aumento das importações.

$\mathrm{m}$ Valor positivo significa aumento da remessa de lucros.

Fonte: Bacha (1984). 
APÊNDICE 2 


\section{OBTENÇÃO DAS VARIÁVEIS REFERENTES A TERMOS DE TROCA}

"Termos de troca" é a relação entre um índice de preços e o deflator implícito do PIB. No presente estudo, procedeu-se ao cálculo de oito séries de termos de troca: para importações agrícolas $\left(\mathrm{P}_{\mathrm{m}} \mathrm{a} / \mathbf{P}_{\mathrm{y}}\right)$, importações não-agrícolas $\left(\mathrm{P}_{\mathrm{m}} \mathrm{n} / \mathrm{P}_{\mathrm{y}}\right)$; exportações agrícolas $\left(\mathrm{P}_{\mathrm{x}}{ }^{\mathrm{a} / \mathrm{P}_{\mathrm{y}}}\right)$ e não-agrícolas $\left(\mathrm{P}_{\mathrm{x}}{ }^{\mathrm{n}} / \mathrm{P}_{\mathrm{y}}\right)$, cada uma com duas bases de ponderação de preços: 1971/73 e 1986/88.

A obtenção dos dados de termos de troca é explicitada a seguir, tomando-se o exemplo dos termos de troca para as importações agrícolas $\left(\mathrm{P}_{\mathrm{m}} \mathrm{a} / \mathrm{P}_{\mathrm{y}}\right)$. Considere-se as importações agrícolas correntes $\left(\mathrm{M}^{\mathrm{a}}\right)$, que são o produto de um índice de preços $\left(\mathrm{P}_{\mathrm{m}}{ }^{\mathrm{a}}\right.$ ), por um índice de quantum (quantidade) $\mathrm{J}^{\mathrm{a}}$ (ou importações a preços constantes), conforme segue:

$$
\mathbf{M}_{\mathrm{a}}=\mathbf{P}_{\mathrm{m}}{ }^{\mathrm{a}} \mathbf{J}_{\mathrm{a}}
$$

ou:

$$
\mathrm{P}_{\mathrm{m}}^{\mathrm{a}}=\mathrm{M}_{\mathrm{a}} / \mathrm{J}_{\mathrm{a}}
$$

As importações agrícolas $\left(\mathrm{M}_{\mathrm{a}}\right)$ resultam do somatório dos valores de todas as $\underline{\underline{n}}$ mercadorias agrícolas importadas, num dado ano $t$ :

$$
M_{a}=\sum_{i=1}^{n} P_{t}^{i} \cdot Q_{t}{ }^{i}
$$


As importações a preços constantes $\left(\mathrm{J}_{\mathrm{a}}\right)$ referem-se a uma somatória de valores com base de preços fixa $\left(\mathrm{P}_{\mathrm{o}}\right)$ :

$$
J_{a}=\sum_{i=1}^{t} P_{t o}^{i} \cdot Q_{t t}^{i}
$$

Assim:

$$
P_{m}{ }^{a}=\sum_{i=1}^{n} P_{t} \cdot Q_{t} / \sum_{i=1}^{n}\left(P_{o} \cdot Q_{t}\right)
$$

Que se trata de um índice de preços de Paasche.

Uma alternativa (ENDO, 1988) para o índice de Paasche pode ser:

$$
\left.P_{o}=1 / \sum_{i=1}^{n}\left(P_{0}^{i} / P_{t}^{i}\right)\left[\left(P_{t}^{i} / Q_{t}^{i}\right) / \sum_{i=1}^{n} P_{t}^{i} / Q_{t}^{i}\right)\right]
$$

Os termos de troca são o resultado da divisão entre um índice de preços (de Paasche) e o deflator implícito, Py. Assim, o quociente (K) entre dois termos de troca, para um mesmo ano, tomadas duas bases de preços $\left(\mathrm{P}_{\mathrm{o}}\right)$ diferentes $(4$ e 7 , por exemplo) será definido como:

$$
\begin{aligned}
& \left.K=\left\{1 / \sum_{i=1}^{n}\left(P_{4}^{i} / P_{t}^{i}\right)\left[\left(P_{t}^{i} \cdot Q_{t}^{i}\right) / \sum_{i=1}^{n} P_{t}^{i} \cdot Q_{t}^{i}\right)\right]\right\} /
\end{aligned}
$$



ou: 


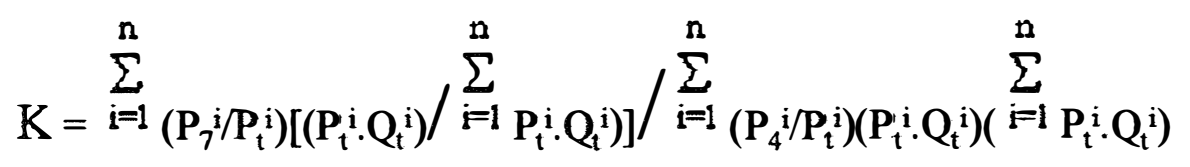

Para uma determinada mercadoria (a):

$$
K^{a}=\left(P_{7}^{a} / P_{t}^{a}\right) \cdot\left[\left(P_{t}^{a} \cdot Q_{t}^{a}\right) /\left(\sum_{i=1}^{n} P_{t}^{a} \cdot Q_{t}^{a}\right)\right] /\left(P_{4}^{a} / P_{t}^{a}\right) \cdot\left[\left(P_{t}^{a} \cdot Q_{t}^{a}\right) /\left(\sum_{i=1}^{n} P_{t}^{a} \cdot Q_{t}^{a}\right)\right.
$$

Para um dado ano $t$, a diferença entre os valores para esse produto a será determinada pelo quociente entre seus relativos de preços, base 4 ou base 7 .

$$
\begin{aligned}
\operatorname{Se}\left(\mathbf{P}_{7} a / P_{t}^{a}\right) /\left(P_{4}{ }^{a} / P_{t}^{a}\right)=1 & \Rightarrow\left(P_{4}^{a} / P_{y}\right)=\left(P_{7}{ }^{a} / P_{y}\right) \\
>1 & \Rightarrow\left(P_{4}^{a} / P_{y}\right)>\left(P_{7} a / P_{y}\right) \\
<1 & \Rightarrow\left(P_{4} a / P_{y}\right)<\left(P_{7}{ }^{a} / P_{y}\right)
\end{aligned}
$$

No exemplo em foco, verifica-se, para termos de troca de importações agricolas, afastamento entre as duas curvas a partir de 1977 (vide Figura ). Isso indica que esse grupo de mercadorias se encaminhou para aumentar a participação de produtos cujo relativo de preços, base 1986/88, se mostrou menor que o relativo de preços, base 1971/73. Outra interpretação é que esse conjunto de produtos concentrou-se nos bens que baixaram preço ao longo do período. 